\title{
A standardized database of Marine Isotopic Stage 5e sea-level proxies on tropical Pacific islands
}

\author{
Nadine Hallmann ${ }^{1}$, Gilbert Camoin ${ }^{1}$, Jody M. Webster ${ }^{2}$, and Marc Humblet ${ }^{3}$ \\ ${ }^{1}$ Aix-Marseille Université, CNRS, IRD, INRAE, Coll France, CEREGE, Europôle Méditerranéen de l'Arbois, \\ BP80, 13545 Aix-en-Provence CEDEX 4, France \\ ${ }^{2}$ Geocoastal Research Group, School of Geosciences, The University of Sydney, \\ New South Wales 2006, Sydney, Australia \\ ${ }^{3}$ Department of Earth and Planetary Sciences, Graduate School of Environmental Studies, \\ Nagoya University, Nagoya 464-8601, Japan \\ Correspondence: Nadine Hallmann (hallmann@cerege.fr)
}

Received: 1 September 2020 - Discussion started: 24 November 2020

Revised: 1 May 2021 - Accepted: 6 May 2021 - Published: 14 June 2021

\begin{abstract}
Marine Isotope Stage 5 deposits have been reported on many tropical Pacific islands. This paper presents a database compiled through the review of MIS 5e (last interglacial - LIG) coral reef records from islands belonging to French Polynesia (Anaa, Niau, Makatea, Moruroa, Takapoto, Bora Bora), the Hawaiian Islands (Oahu, Lanai, Midway Atoll), Tuvalu, Kiribati (Christmas Island, Tarawa), the Cook Islands (Mangaia, Atiu, Mitiaro, Mauke, Pukapuka, Rakahanga, Rarotonga), Tonga, Samoa, the Federal States of Micronesia, the Mariana Islands, the Marshall Islands (Enewetak, Bikini), New Caledonia, Papua New Guinea, the Solomon Islands, Vanuatu, Fiji and Niue. Studies reporting other sea-level indicators dated to other Pleistocene interglacials and Holocene sea-level indicators were not inserted in the database but are included in this data description paper for completeness. Overall, about 300 studies concerning Pleistocene and Holocene sea-level indicators have been reviewed, and finally 163 age data points and 94 relative sea-level (RSL) data points from 38 studies on the MIS 5e have been inserted in the database. An additional 155 age data points have been reviewed; i.e. the tropical Pacific islands database contains 318 age data points. The main sea-level indicators include emerged coral reef terraces, but also reef units recovered in drill cores from a few islands, thus reflecting the diversity of tectonic settings and sampling approaches. Future research should be directed towards better constrained RSL reconstructions, including more precise chronological data, more accurate elevation measurements and a better refinement of the palaeo-water-depth significance of coralgal assemblages. The database for tropical Pacific islands is available open access at this link: https://doi.org/10.5281/zenodo.3991672 (Hallmann and Camoin, 2020).
\end{abstract}

\section{Introduction}

In this paper, we describe in detail the background information used to build the standardized database of tropical Pacific islands. This database was compiled as a contribution to the World Atlas of Last Interglacial Shorelines (WALIS) ESSD special issue. The database was created using the WALIS interface, which is available at this link: https://warmcoasts.eu/world-atlas.html (last access: 22 April 2021). The WALIS interface al- lows the standardized insertion into a mySQL database on relative sea-level indicators and associated ages. The database presented in this study has been downloaded from the interface as an .xls file. The database presented here is open access and is available under this link: https://doi.org/10.5281/zenodo.3991672 (Hallmann and Camoin, 2020). Each field in our database is described at the following link: https://doi.org/10.5281/zenodo.3961543 (Rovere et al., 2020). The open access will enable the rapid 


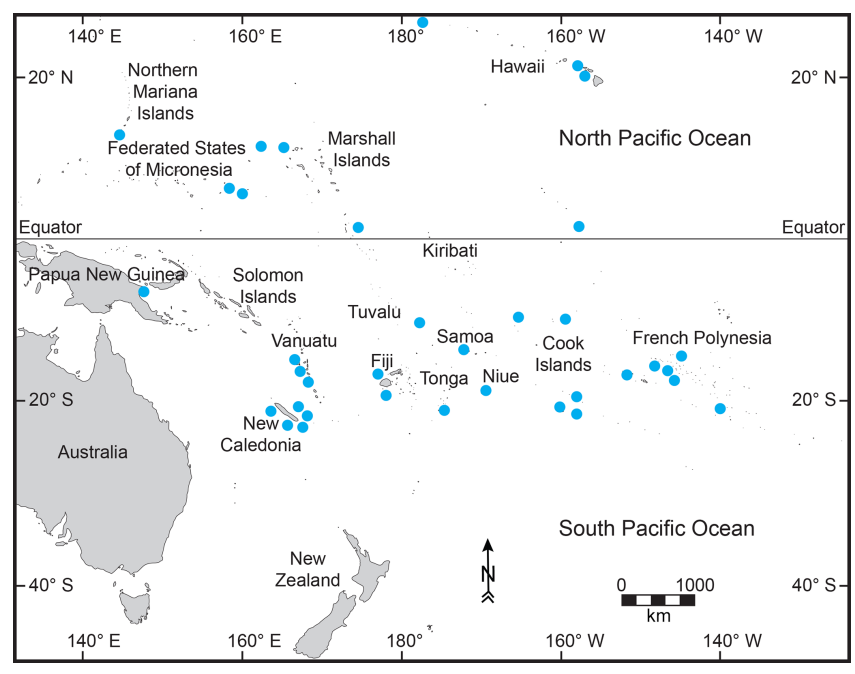

Figure 1. Map showing the tropical Pacific islands considered in this article (blue dots).

and wide dissemination of the data that form the basement of this work and which in turn may trigger new studies in this field. The database presented here will be useful for scientists studying relative sea-level changes, reef geology, tectonics and geodynamics of the Pacific region, as well as palaeoceanographers.

More than 200 studies on Marine Isotopic Stage (MIS) 5 coral reef records in the tropical Pacific have been reviewed. Of those, data from 38 studies have been included in the database. The geographical distribution of the studied islands from 14 nations is shown in Fig. 1. Overall, the database contains $315 \mathrm{U}$-series data points and three electron spin resonance data points. Evaluation of the quality of radiometric ages includes the mineralogical assessment, but also the closed- versus open-system behaviour of radioisotopes. Data points obtained outside closed-system conditions are highlighted in the database. The information on the acceptance of radiometric ages has often been directly taken from the original publication. In addition, the quality of the ages that are reported in the WALIS database has been reviewed by Chutcharavan and Dutton (2020), who compiled a U-series database for MIS 5e corals (see this special issue). We inserted in the database 163 age data points and 94 relative sea-level (RSL) data points from 38 studies on the MIS 5e. An additional 155 age data points inserted by Chutcharavan and Dutton (2020) have been reviewed; i.e. the tropical Pacific islands database contains 318 age data points.

In the following, we first give an overview of the published literature related to last interglacial (LIG) sea-level indicators in the tropical Pacific islands, in order to give the reader a sense of the historical background upon which our review was done. Then, we describe the types of sealevel indicators as well as the elevation measurement techniques and sea-level datums reported in the literature and the method used to reconstruct MIS 5e palaeo-RSL. We then report a detailed description of the data points located in each administrative province/region within the area of interest, where sea-level data were reviewed (Sect. 5). Section 6.1 contains the description of a number of studies where the presence of different peaks in the LIG sea-level record was discussed in literature. While in our database we only reviewed specifically MIS 5e data, we encountered a number of studies where other Pleistocene shorelines were dated or described (Sect. 6.2 and 6.3), as well as Holocene sea-level data (Sect. 6.4). Major controversies regarding MIS 5e are highlighted in Sect. 6.5, while uncertainties associated with estimating palaeo-RSL from the data in the database are detailed in Sect. 6.6. Large RSL uncertainties and limitations in the accuracy of RSL reconstructions can be considered for studies concerning MIS 5e coral reef records from the tropical Pacific islands. The data quality is mostly affected by the quality of RSL data and, to a lesser extent, by the quality of age information (see Sect. 6.6). We further present future research directions (Sect. 7) that may stem from our data compilation. Future work using more accurate dating methods and elevation measurements as well as a more detailed identification of the collected coral samples are essential to better constrain the MIS 5e RSL dataset concerning the tropical Pacific islands.

\section{Literature overview}

The sea-level database described by this article focuses on tropical Pacific islands, which cover most of the intertropical realm of the Pacific Ocean from the Hawaiian archipelago to the north to New Caledonia to the south and from Mariana Islands and Papua New Guinea to the west to French Polynesia to the east.

Last interglacial (LIG) coral reef records of relative sealevel (RSL) change on tropical Pacific islands were mostly investigated on subaerially exposed reef terraces. Since the pioneer work of Veeh (1966), which focused on the dating of corals from different islands (Hawaiian Islands, French Polynesia, Cook Islands), extensive studies have been conducted in many islands across this vast region. Some of these studies have used the LIG shorelines to reconstruct tectonic uplift, especially in Papua New Guinea and Vanuatu. Submerged coral reef deposits related to the LIG, forming locally wellidentified terraces, have been investigated since the beginning of the 20th century and the first drilling in Funafuti (Tuvalu). Drill cores including reef units related to the LIG have been collected between the 1950s and the 1980s on Enewetak (Marshall Islands), Midway Atoll, Moruroa (French Polynesia) and Tarawa (Kiribati) and more recently in New Caledonia and Bora Bora (French Polynesia).

All reviewed studies concerning LIG reef records from tropical Pacific islands (Fig. 1) are summarized hereafter. 
French Polynesia (Fig. 2). Since the early 1960s, the geology of Moruroa has been investigated through the drilling of a number of deep vertical and inclined boreholes carried out in the modern lagoon and on the reef rim. Lalou et al. (1966) and Labeyrie et al. (1969) studied reef units from the last 300000 years. Trichet et al. (1984) described the general stratigraphy of Moruroa based on three cores. Camoin et al. (2001) dated four $300 \mathrm{~m}$ long drill cores from the reef rim and reconstructed RSL changes over the past 300000 years, including the identification of MIS 5e. The most recent study on a Moruroa drill core by Braithwaite and Camoin (2011) focused on the study of carbonate sedimentology and diagenetic features of these cores.

The earliest study on emerged Pleistocene coral reef terraces was performed by Veeh (1966), who dated in situ fossil corals on Anaa, Niau and Makatea, followed by Pirazzoli et al. (1988a), who dated LIG reefs on Anaa. Montaggioni (1985), Montaggioni et al. (1985), and Montaggioni and Camoin (1997) studied LIG reef terraces on Makatea. More recent studies by Montaggioni et al. (2018, 2019a, b) considered that some reef units have formed during Pleistocene high RSL, including MIS 5e, on Takapoto but did not provide dating results. In addition, Gischler et al. (2016, 2019) reported the occurrence of a Pleistocene reef unit attributed to MIS 5e in Bora Bora drill cores.

Cook Islands (Figs. 3 and 4). Schofield (1910) reported on late Quaternary RSL changes on Rarotonga in the southern Cook Islands. The earliest study providing datings on LIG reef limestones in the southern Cook Islands (Mangaia) was performed by Veeh (1966). Subsequent studies have been conducted by Stoddart et al. (1985), Spencer et al. (1987, 1988) and Stoddart et al. (1990). Woodroffe et al. (1991) worked on the stratigraphy and chronology of the southern Cook Islands and presented new U-series ages for Atiu, Mitiaro and Mauke. Gray et al. (1992) studied the geochronology and subsurface stratigraphy of Pukapuka and Rakahanga in the northern Cook Islands based on drill cores from the lagoon.

Samoa. The early study by Kear and Wood (1959) described LIG reefs in Samoa. Stice and McCoy (1986) studied the geology of the Manu'a Islands and reported on the occurrence of carbonate deposits.

Niue (Fig. 5). Different terraces on Niue were explored at the beginning of the 20th century (Agassiz, 1903; David, 1904). Schofield (1959) identified seven terraces. A LIG reef sequence has been reported by Paulay (1988), Paulay and Spencer (1992), Spencer and Paulay (1994) and Wheeler (2000). More recent studies further described the different terraces on Niue (Terry and Nunn, 2003; Nunn and Britton, 2004; Kennedy et al., 2012).

Tonga (Fig. 6). Taylor (1978) and Yonekura (1983) have attributed reef deposits from the Tongatapu block to the LIG.

Fiji (Fig. 7). Despite pioneer geomorphological works by Dana (1872) and Moore (1889), and reports on late Quaternary RSL changes by Schofield (1910), LIG deposits from
Fiji were reported for the first time in the late 1970s by Taylor (1978), who dated reefs on Yasawa Island. In the late 1990s, Nunn and Omura (1999) studied exposed reef terraces around Kadavu Island. The most recent studies by Nunn et al. (2002) and Nunn and Omura (2003) summarized the levels of emerged LIG shorelines on the northeastern Fiji Islands and compared them to those from the western Fiji Islands.

Tuvalu. Data regarding LIG deposits from Tuvalu are restricted to the $340 \mathrm{~m}$ long drill core that was carried out by the Coral Reef Expedition of The Royal Society in 18961898 on Funafuti Atoll. This drill core was used to interpret the origin and history of atoll formation (Bonney, 1904) and test Darwin's subsidence theory (Darwin, 1842). Despite a detailed study of these reef cores (Bonney, 1904), the core was originally interpreted as a modern reef deposit overlying Pleistocene limestone (Hinde, 1904), and no chronological frame was established before Ohde et al. (2002), who considered that LIG reef deposits must be deeper than $24.2 \mathrm{~m}$ below the modern surface. Since then, the Funafuti cores have been mentioned in general reviews regarding the development of coral reef islands (e.g. McLean and Woodroffe, 1994; Spencer et al., 2008).

Kiribati (Fig. 8). In 1981, $30 \mathrm{~m}$ long drill cores reaching Pleistocene limestone have been collected on Tarawa during a hydrogeological investigation by an Australian government team. These cores have been dated later by Marshall and Jacobson (1985). Woodroffe and McLean (1998) reported Useries ages from an outcrop of LIG limestone on Christmas Island.

Solomon Islands. Stearns (1945) studied elevated benches in the southwest Pacific and correlated the different levels between the Solomon Islands, Vanuatu, the Mariana and Hawaiian Islands. The geology of the Solomon Islands was then studied in the 1950s by Grover (1958), while their geomorphology was investigated later by Stoddart (1969), who reported on elevated shorelines, terraces and tidal notches on different island groups.

Vanuatu (Fig. 9). Uplifted Quaternary reef terraces on Vanuatu islands, specifically Santo, Malakula and Efate, have been identified and partially described since the late $1960 \mathrm{~s}$ and the 1970s (Mitchell, 1966, 1969, 1971; Robinson, 1969; Mallick and Greenbaum, 1977; Ash et al., 1978). After these first descriptions, a reconnaissance study was carried out by Neef and Veeh (1977), who published the first U-series ages on Malo and Efate, immediately followed by Bloom et al. (1978), who focused on the dating of LIG reefs from Efate. In the 1980s, the vertical movements in the New Hebrides (Vanuatu) Island arc were reconstructed based on the dating of the uplifted coral reef terraces, and several investigations provided additional dating results on terraces from Santo, Malakula, Efate and Torres Islands (Jouannic et al., 1980, 1982; Lecolle and Bernat, 1985; Taylor et al., 1980, 1985). Taylor et al. (1987) compared contemporary coseismic and nonseismic with quaternary vertical movements 


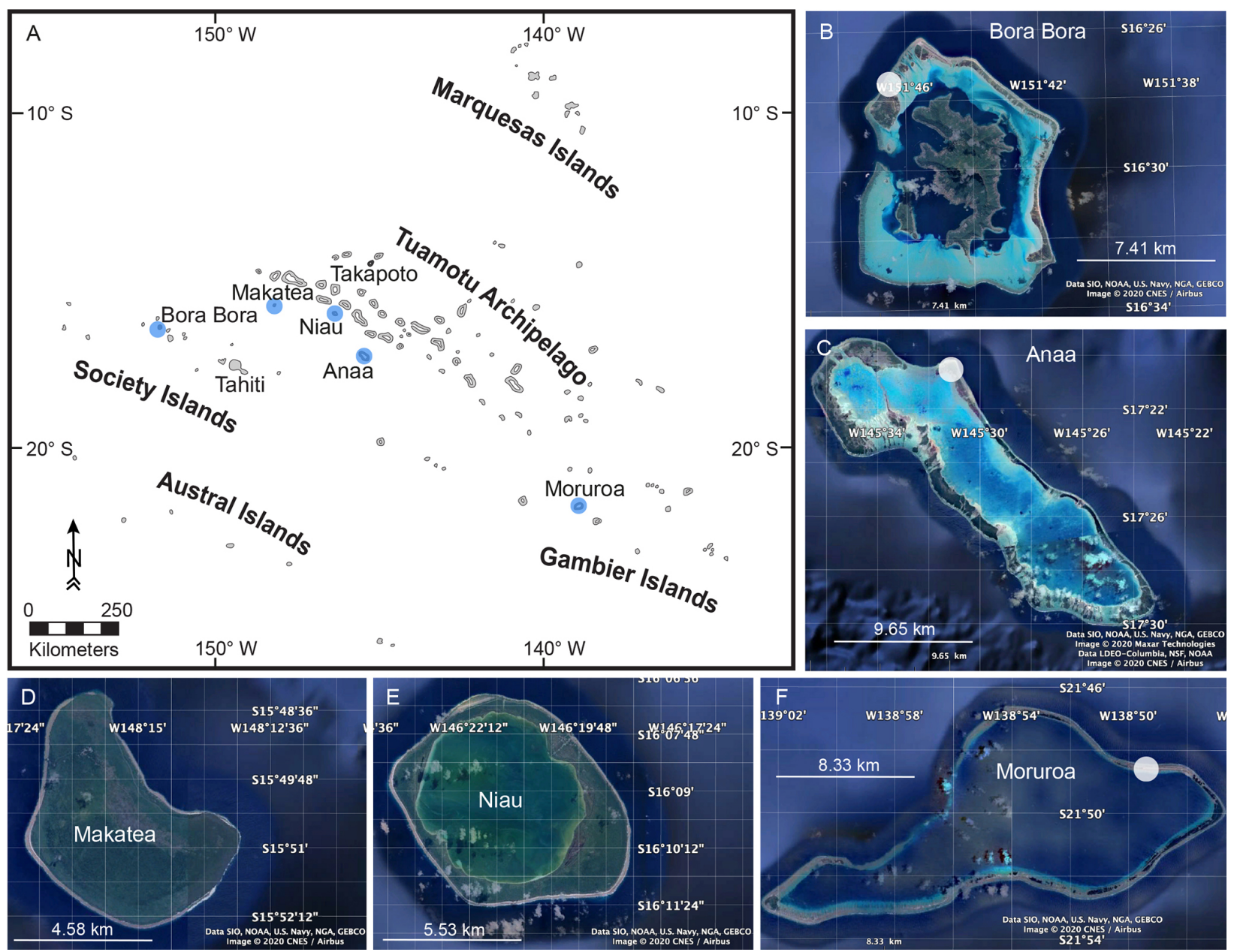

Figure 2. Map showing islands in French Polynesia considered in this article (blue dots). Study sites are indicated by white circles. (C) Google Earth 2020 (b-f).

based on the analysis of partially emerged corals and reef terraces in the central Vanuatu Arc. Edwards et al. (1987a, b) have provided precise chronological data on exposed reef terraces from Efate. Chronological data obtained on uplifted coral reef terraces were used by Taylor et al. (2005) to reconstruct rapid vertical movements in the New Hebrides forearc. Since the beginning of the current century, additional studies have been carried out on Malakula (Cabioch and Ayliffe, 2001) and Tanna (Neef et al., 2003) and significantly advanced the chronological frame of Pleistocene raised reefs. On Tanna, the studied reefs and raised lagoonal deposits range in age from the Holocene to MIS 7 (Neef et al., 2003).

New Caledonia (Fig. 10). Early studies on Pleistocene reef terraces, including the LIG, were carried out in the 1970s and early 1980s by Launay and Récy (1972), Coudray (1976), Bernat et al. (1976), Marshall and Launay (1978), and Gaven and Bourrouilh-Le Jan (1981) and were focused on their dating and use for the reconstruction of neotectonic movements in the Loyalty Islands (Maré, Lifou and Ouvéa). These results have been summarized by Maurizot and Lafoy (2003) in their geological map of Maré Island. The drilling of modern reefs from the western coast of New Caledonia in the 1970s (Coudray, 1971), late 1990s (Cabioch et al., 1996, 1999) and after 2000 (Frank et al., 2006; Cabioch et al., 2008; Montaggioni et al., 2011; Hongo and Wirrmann, 2015) aimed at reconstructing the development pattern of fringing and barrier reefs. Drill cores from the Chesterfield Islands that are located about $500 \mathrm{~km}$ to the WNW of New Caledonia have been studied with the same objective by Degaugue-Michalski (1993).

Papua New Guinea (Fig. 11). Uplifted Quaternary reef terraces from Huon Peninsula (Papua New Guinea) represent a classical site of RSL change studies in support of the astronomical theory of climate change. Early studies and first attempts to establish an accurate chronological frame for these coral reef terraces were carried out in the 1970s by Veeh and Chappell (1970), Chappell (1974), and Bloom et al. (1974). Since then, the uplifted terraces from Huon Peninsula have been regularly investigated with the same general objective in the 1980s by Aharon (1983), Chappell (1983), and Aharon 


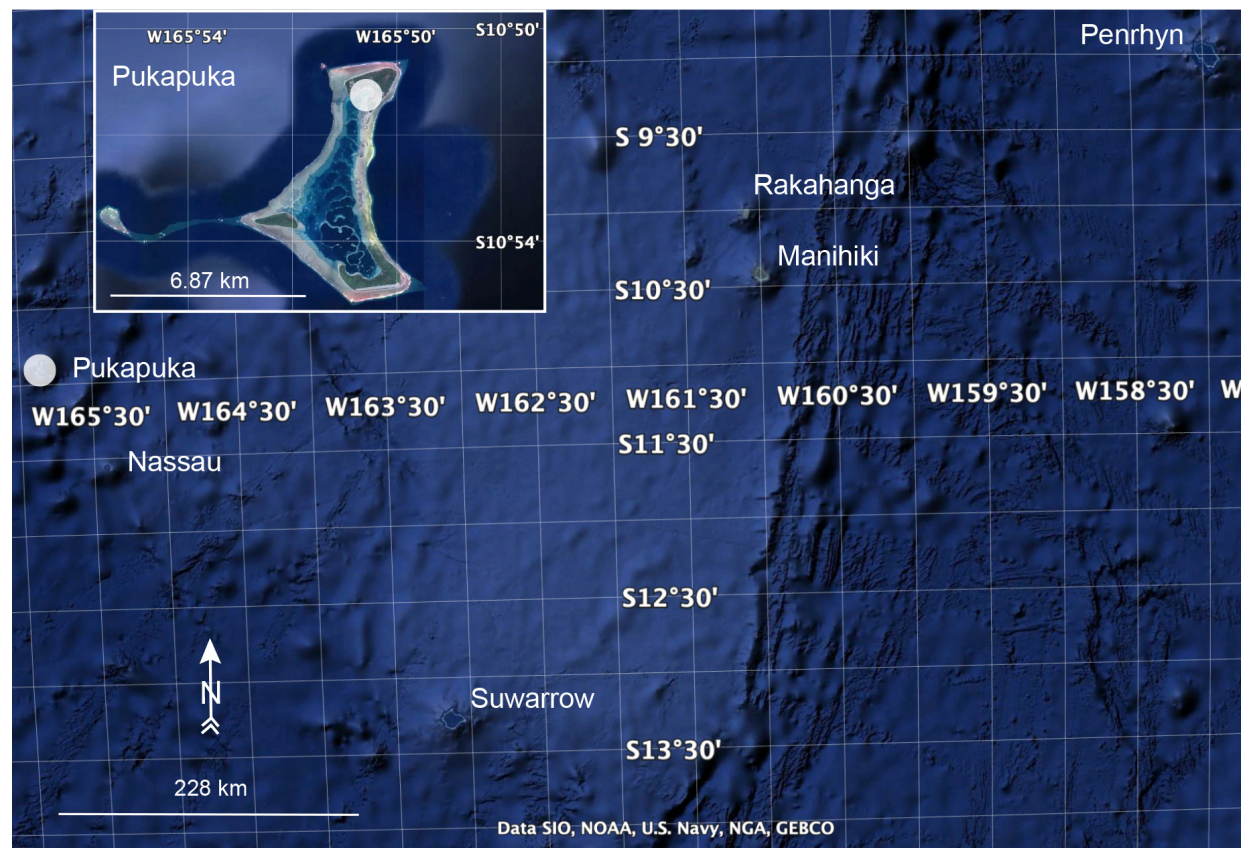

Figure 3. Map showing the northern Cook Islands. Study site on Pukapuka is indicated by a white circle. () Google Earth 2020.

and Chappell (1986); in the 1990s by Stein et al. (1993) and Esat et al. (1999); and, in the early 2000s, by Cutler et al. (2003).

Federated States of Micronesia. Ayers and Vacher (1986), Anthony (1996a, b, c) and Fletcher and Richmond (2010) mentioned Pleistocene limestones, including the LIG period, in this region.

Mariana Islands (Fig. 12). The geologic history of Guam was first studied by Stearns (1940), who reported on the deposition of Pleistocene limestone on volcanic substrate. Stearns (1945), Tayama (1952) and Emery (1962) described "shore benches" related to sea level. Cloud (1954) correlated stratigraphic sections throughout the West Pacific, including Guam. In the early 1950s, a programme by the Corps of Engineers, U.S. Army and U.S. Geological Survey focused on geology, soils and water of Guam (Tracey et al., 1959, 1964), including a detailed description of submarine and emerged coral reef terraces. Lower terraces on Guam, less than $15 \mathrm{~m}$ above modern sea level, are comparable to limestones that were described at the same elevation on Saipan, Northern Mariana Islands (Tracey et al., 1964) and assigned to the late Pleistocene (Cloud et al., 1956). Further studies on Guam reef terraces included their lithological description (Emery, 1963), the provision of U-series ages obtained on MIS 5e limestone and estimated tectonic movements (Randall and Siegrist, 1996) and the reconstruction of RSL changes since MIS 5e (Miklavič et al., 2012). Following up the work by Cloud et al. (1956) on the geology of Saipan, Weary and Burton (2011) mapped the island and stated that the Tanapag Limestone is usually found at elevations of less than $30 \mathrm{~m}$.
The latest study by Muhs et al. (2020) provided U-series ages for the emergent reef of the Tanapag Limestone in Saipan, which formed during the LIG period.

Marshall Islands. Five drill cores extracted from Bikini atoll in 1947 were first studied by Ladd et al. (1948), who described subaerial horizons in those cores. Emery et al. (1954) further described cores from Bikini. Drillings on Enewetak were performed in the early 1950s, and drill cores have been studied by Ladd et al. (1953), Potratz et al. (1955), Ladd and Schlanger (1960), Schlanger (1963), and Thurber et al. (1965). Schlanger (1963) has shown similarities between cores from Enewetak and Bikini. Two shallow drilling programmes were initiated in the early 1970s: PACE (19711972; Henry et al., 1974) and EXPOE with 46 holes down to $90 \mathrm{~m}$ on Enewetak (1973-1974; Couch et al., 1975). Couch et al. (1975) confirmed the occurrence of subaerial unconformities in many drill cores. Tracey and Ladd (1974) described unconformities in the Bikini drill core, which could also be partly recognized in Enewetak drill cores. Szabo et al. (1985) presented dating results from two drill cores extracted from the Enewetak reef flat during the PACE programme. During the Pacific Enewetak Atoll Crater Exploration (PEACE) programme (1984-1985), the U.S. Geological Survey investigated two craters formed by nuclear detonations in 1958 (Henry et al., 1986; Henry and Wardlaw, 1990). Ludwig et al. (1988) studied a $350 \mathrm{~m}$ long drill core of Neogene lagoonal, shallow-water carbonates from Enewetak. Quinn and Matthews (1990), Wardlaw and Quinn (1991), and Quinn (1991) studied the post-Miocene sea-level history of Enewetak. 

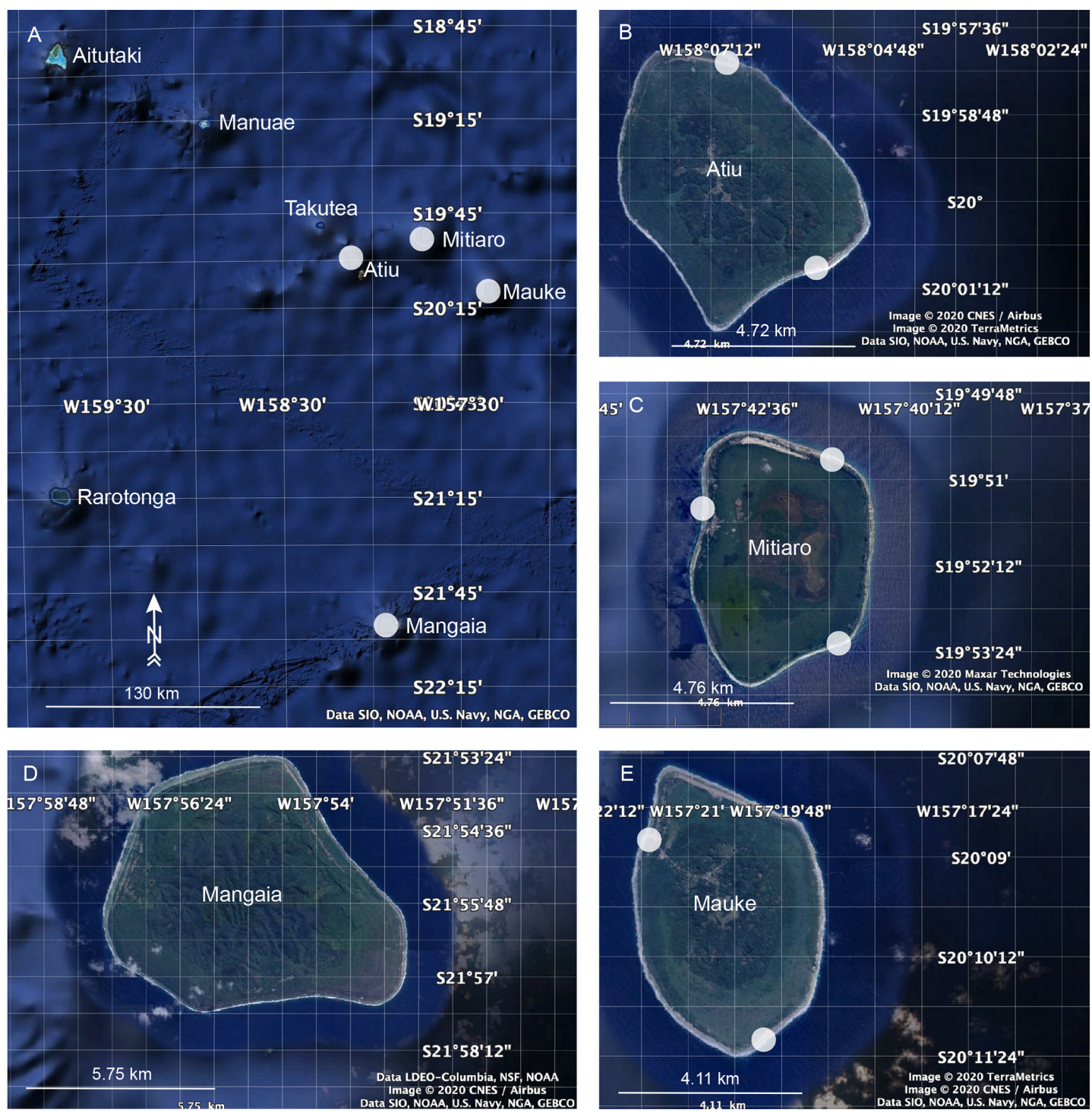

Figure 4. Map showing islands in the southern Cook Islands considered in this article (white circles). Study sites are indicated by white circles. (C) Google Earth 2020.

Hawaii (Fig. 13). Stearns (1935a, b, c) and Wentworth and Hoffmeister (1939) first studied Pleistocene shorelines on the islands of Oahu and Maui. In 1960, drill cores were collected on Midway Atoll and studied in the following decades (e.g. Ladd et al., 1967, 1970; Wells, 1982). Stearns and Chamberlain (1967) described deep cores extracted from Oahu to better understand the geologic history. Several studies provided ages and demonstrated that the Waimanalo limestone on Oahu corresponds to the LIG. Veeh (1966) and $\mathrm{Ku}$ et al. (1974) provided the first dating results of those emerged terraces. Further chronological studies concerning the Waimanalo deposits included those from Sherman et al. (1993), Muhs and Szabo (1994), and Szabo et al. (1994). Muhs et al. (2002) performed additional datings with a higher precision at the Szabo et al. (1994) study sites. The latest ages of reef deposits from Oahu have been reported by Hearty et al. (2007) and McMurtry et al. (2010). Rubin et al. (1995, 2000) provided U-series data for the Hulopoe gravel on Lanai containing corals corresponding to MIS 5e and MIS 7.

\section{Sea-level indicators}

The main features associated with last interglacial (LIG) relative sea levels (RSLs) on tropical Pacific islands are exposed coral reef terraces. In addition, submerged coral reef deposits related to the LIG, forming locally well-identified terraces, have been drilled on land on several islands, such as Funafuti (Tuvalu), Enewetak (Marshall Islands), Midway Atoll, Moruroa and Bora Bora (French Polynesia), Tarawa (Kiribati), and New Caledonia. 

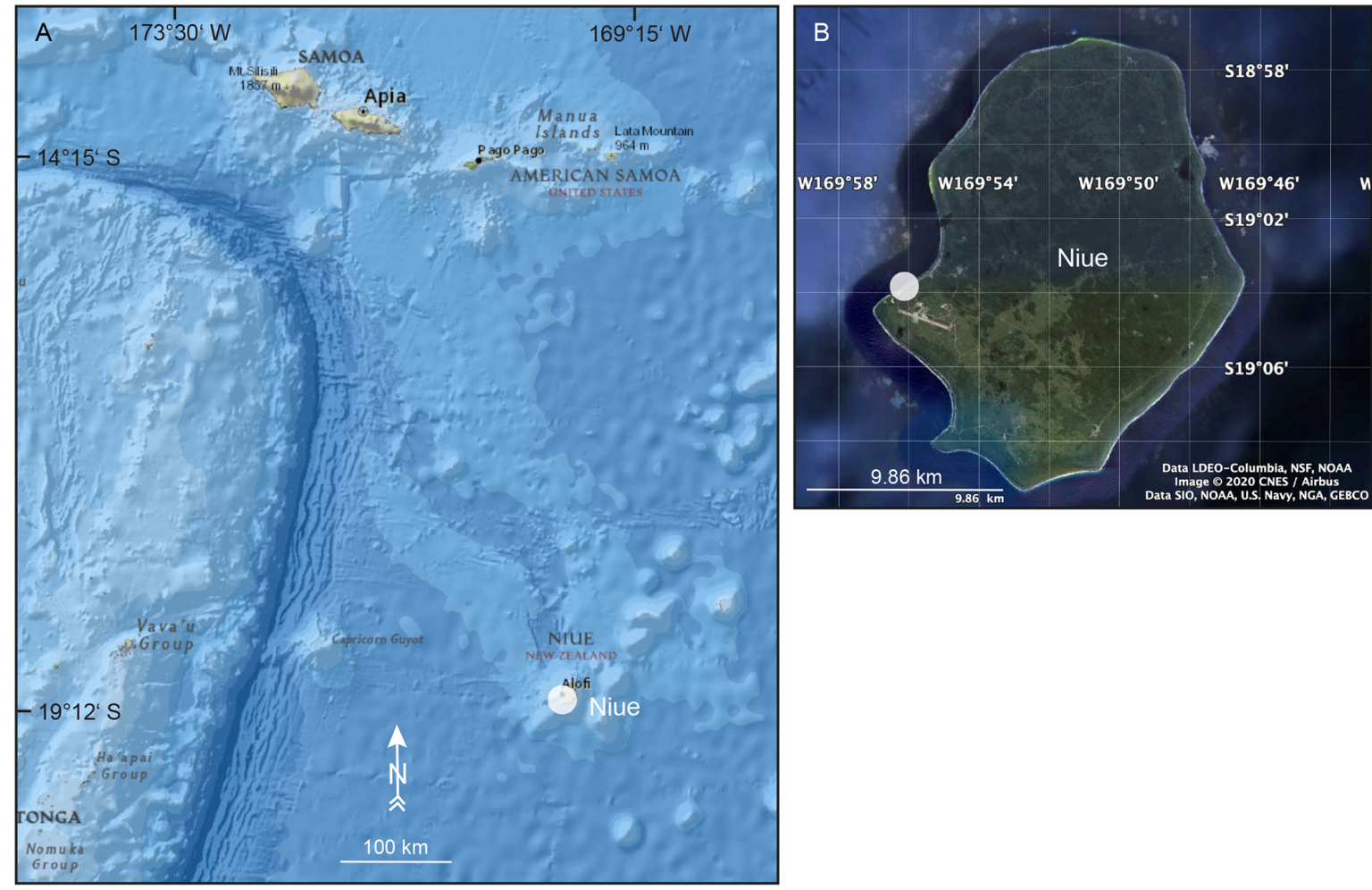

Figure 5. Map showing the island of Niue. Study site on Niue is indicated by a white circle. Basemap: "National Geographic Map", with data from National Geographic, Esri, Garmin, HERE, UNEP-WCMC, USGS, NASA, ESA, METI, NRCAN, GEBCO, NOAA and INCREMENT P Corp (a). (C) Google Earth 2020 (b).

In general, palaeo-RSL is determined from the average elevation of the terrace or, if present, from the elevation of the highest in situ corals which are usually found on the palaeo reef crest (Rovere et al., 2016). However, the identification of coral assemblages that characterize coral reef terraces and the definition of the relevant water depth range estimates may provide a more accurate indication of the palaeo-RSL. Single corals and coral assemblages have been described in some studies related to LIG reefs on tropical Pacific islands. Since their palaeo-water-depth significance has been barely reported in the relevant studies, we have compiled data published in two databases: OBIS (Ocean Biodiversity Information System; https://obis.org, last access: 22 April 2021) and IUCN (International Union for Conservation of Nature; https://www.iucnredlist.org, last access: 22 April 2021), thus following a similar approach to the one used by Hibbert et al. (2016, 2018). The datasets used are listed on the OBIS and IUCN websites and summarized in Table 2, which presents the best estimates of palaeo-water-depth intervals for corals that were quoted in the literature.

OBIS is a more detailed database, which allows the definition of distribution curves and prediction of the depth ranges at which the relevant species can be found with the highest probability. Data were extracted from the OBIS database using the Mapper tool. Two filters were used on Mapper:
(1) time range: 1990-2020 and (2) depth range: 0-150 (to eliminate potential aberrant depths). Records which had the following characteristics were excluded from the analysis: (1) those for which the difference between max depth and min depth were $>0.2 \mathrm{~m}$ and (2) those for which the "basis of record" was not "human observation" or "machine observation" (i.e. collection specimens were excluded).

All available data were used to define palaeo-water-depth intervals for each species (Table 2). However, the data that have been compiled from OBIS and other databases cover the whole Indo-Pacific region. The value that has been calculated for average and median depths can therefore differ when considering specific islands or areas of the studied area. In most cases, it has been difficult to assign a palaeo-waterdepth based on a single species, as most corals have a wide depth range. Accurate palaeo-water-depth intervals can usually be defined based on coral assemblages. We have primarily selected data for which a precise depth, not a range, was available in the OBIS database.

For some species, which were not identified with certainty, we used close species to define a depth interval (e.g. for Acropora cf. aspera, we have compiled data concerning close species that belong to the "aspera group" of Wallace, 1999: A. aspera, A. pulchra and A. millepora). 

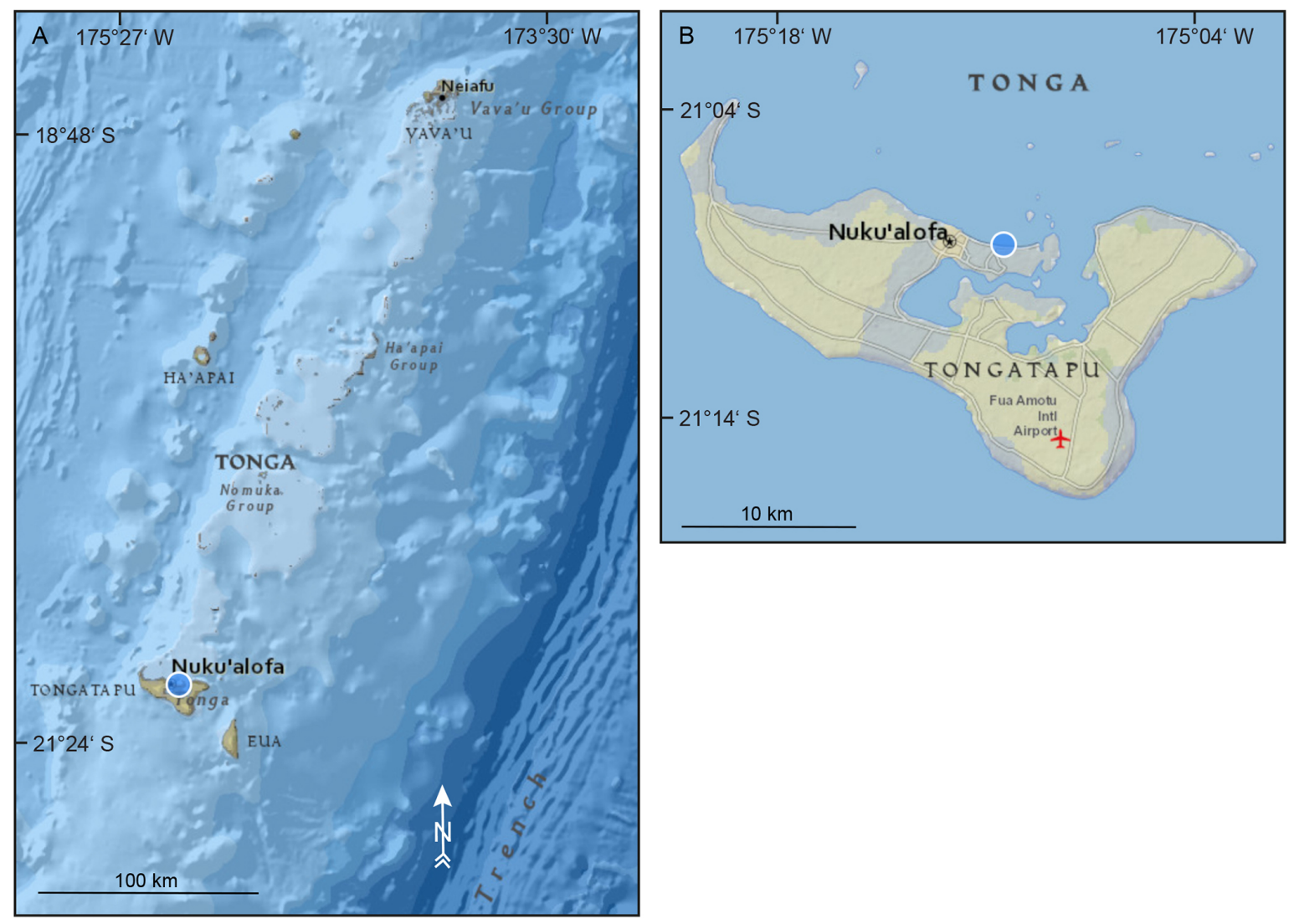

Figure 6. Map showing Tonga. Study site on Tongatapu is indicated by a blue circle. Basemap: "National Geographic Map", with data from National Geographic, Esri, Garmin, HERE, UNEP-WCMC, USGS, NASA, ESA, METI, NRCAN, GEBCO, NOAA and INCREMENT P Corp.

Table 1. Different types of RSL indicators reviewed in this study.

\begin{tabular}{|c|c|c|c|c|}
\hline $\begin{array}{l}\text { Name of RSL } \\
\text { indicator }\end{array}$ & Description of RSL indicator & $\begin{array}{l}\text { Description of ref- } \\
\text { erence water level }\end{array}$ & $\begin{array}{l}\text { Description of } \\
\text { indicative range }\end{array}$ & Indicator reference(s) \\
\hline $\begin{array}{l}\text { Coral reef terrace } \\
\text { (general } \\
\text { description) }\end{array}$ & $\begin{array}{l}\text { Coral-built flat surface, corresponding } \\
\text { to shallow-water reef terrace to reef } \\
\text { crest. The definition of indicative mean- } \\
\text { ing is derived from Rovere et al. (2016), } \\
\text { and it represents the broadest possible } \\
\text { indicative range, which can be refined } \\
\text { with information on living coral ranges. }\end{array}$ & $\begin{array}{l}\text { (mean lower low } \\
\text { water }+ \text { breaking } \\
\text { depth) } / 2\end{array}$ & $\begin{array}{l}\text { Mean lower low } \\
\text { water - breaking } \\
\text { depth }\end{array}$ & Rovere et al. (2016) \\
\hline
\end{tabular}

Porites is the most frequent coral reported in LIG reefs from tropical Pacific islands. However, it cannot be generally used to constrain the palaeo-water-depth interval as it displays a wide depth range when it is not identified at the species level. The morphology of Porites colonies may nevertheless give some indications on a gross palaeo-waterdepth distribution.

\section{Elevation measurements}

Almost all studies used auto/hand level to measure elevations of relative sea-level (RSL) indicators (Table 3); fewer studies used theodolite and rod or metre tape and rod. The elevation measurement technique has not been reported in many of the reviewed studies but was most probably hand level or metered tape (Table 3). The sea-level datums reviewed in this study include mean sea level (MSL), mean high tide (MHT), mean low tide (MLT), mean low water springs (MLWS) and 

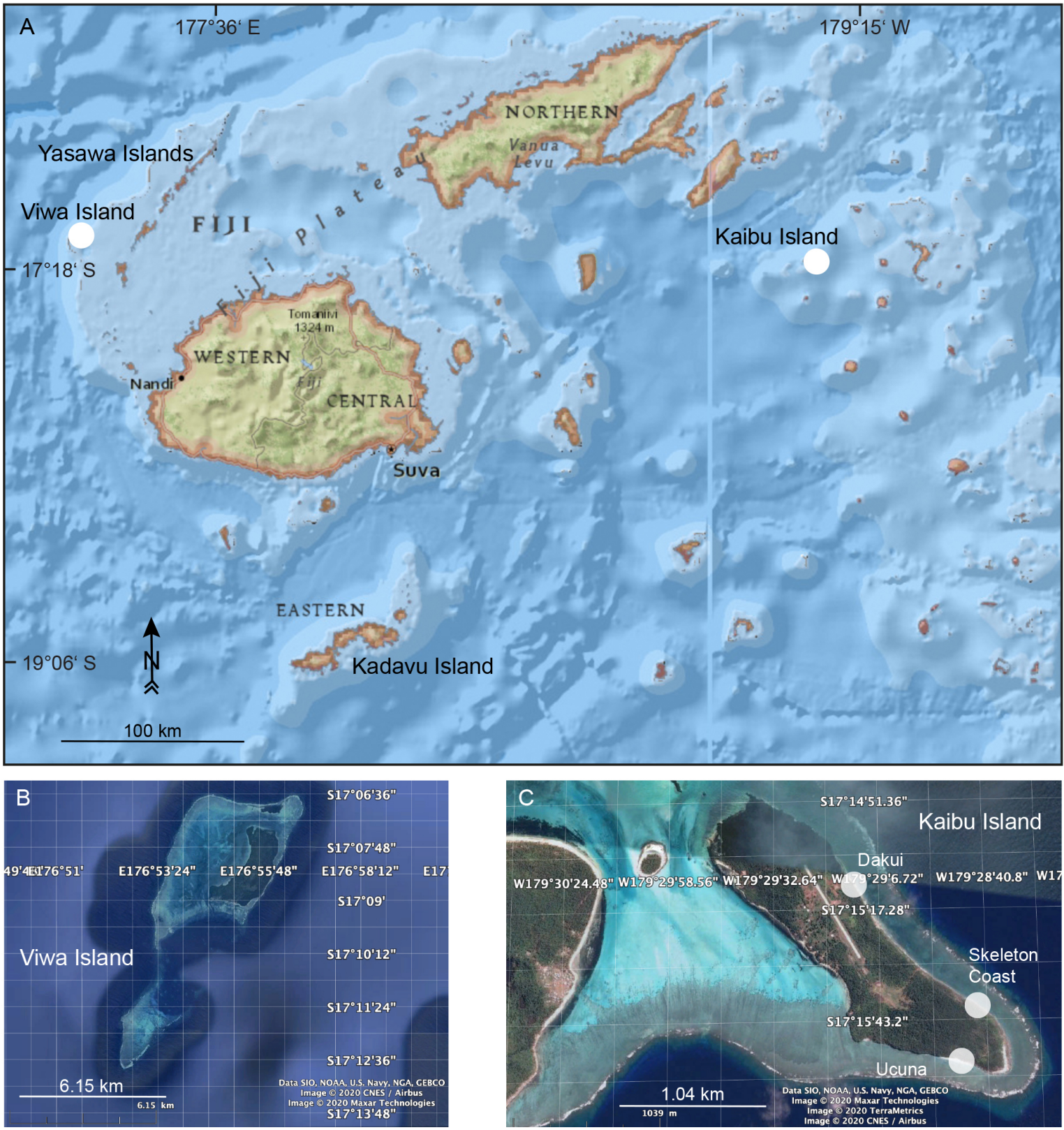

Figure 7. Map showing islands in Fiji considered in this article (white circles). Study sites on Kaibu Island are indicated by white circles. Basemap: "National Geographic Map", with data from National Geographic, Esri, Garmin, HERE, UNEP-WCMC, USGS, NASA, ESA, METI, NRCAN, GEBCO, NOAA and INCREMENT P Corp (a). () Google Earth 2020 (b-c).

modern reef (Table 4). In several studies the sea-level datum has not been reported and has been assumed to be MSL (Table 4).

\section{Relative sea-level indicators}

Because they correspond to easily accessible coral reef archives of sea-level change on many tropical and subtropical coasts, the last interglacial (LIG) terraces have received much attention since the seminal works from Mayer (1917) and Daly (1920) on Samoa and other Pacific islands (Camoin and Webster, 2015).

Most of the tropical Pacific islands are underlain by the large northwestward-moving Pacific plate that is generated at the East Pacific Rise and the Pacific-Antarctic Ridge (see Fig. 1 in Neall and Trewick, 2008). The archipelagos and islands from the western part of the studied area developed in a complex geodynamic setting resulting from the relative motions of the Pacific and the Australian and Eurasian plates. 

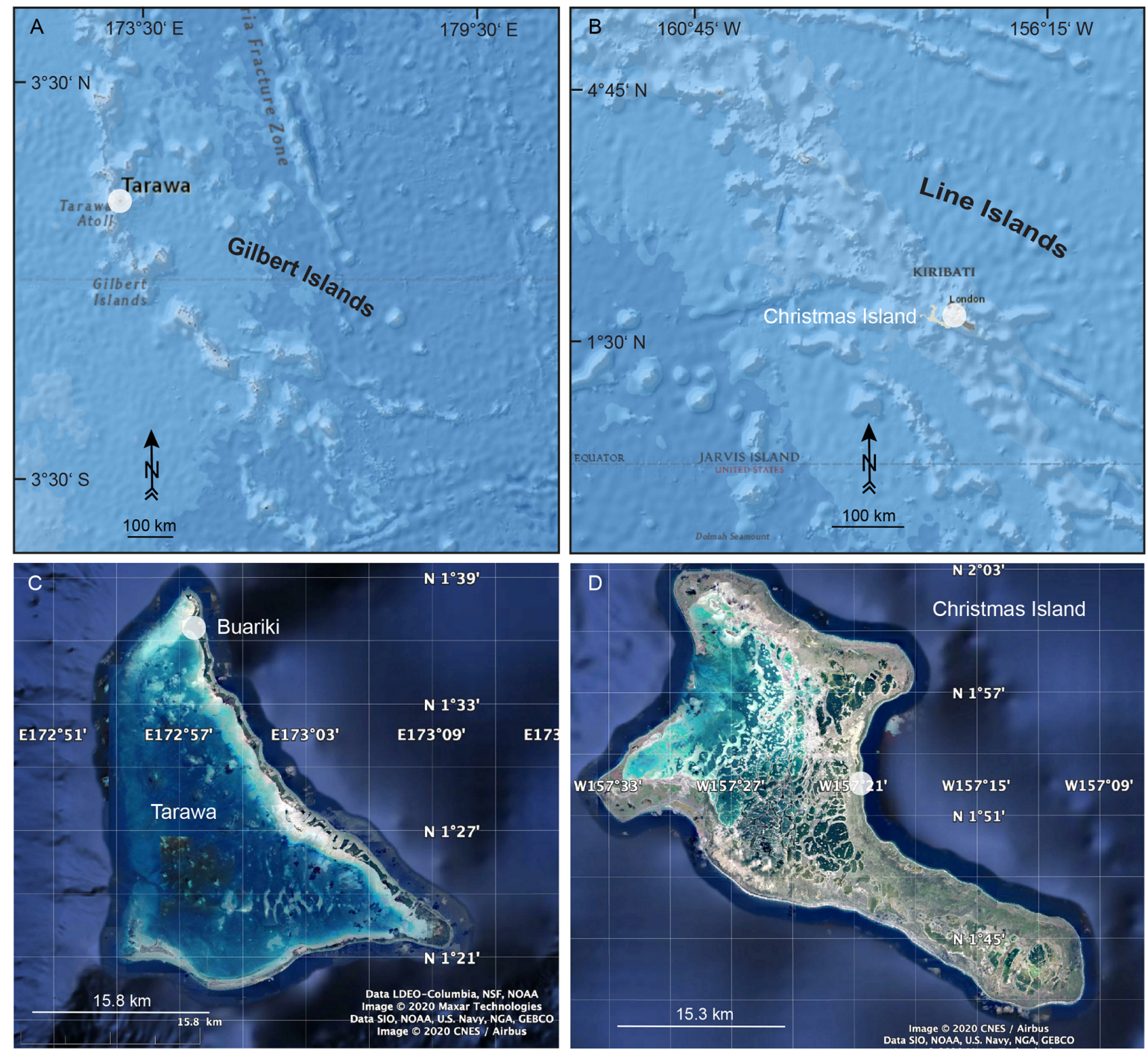

Figure 8. Map showing islands in Kiribati considered in this article (white circles). Study sites on Tarawa and Christmas Island are indicated by white circles. Basemap: "National Geographic Map", with data from National Geographic, Esri, Garmin, HERE, UNEP-WCMC, USGS, NASA, ESA, METI, NRCAN, GEBCO, NOAA and INCREMENT P Corp (a-b). @ C Google Earth 2020 (c-d).

The 16 archipelagos and islands reported in the database illustrate the exceptional diversity of tropical Pacific islands, which is mainly related to their dynamic and complex geological history. They have originated as linear chains of volcanic islands on the above plates, atolls, uplifted coral reef islands, fragments of continental crust and obducted portions of adjoining lithospheric plates and have also resulted from subduction along convergent plate margins (Neall and Trewick, 2008). This complex history has generated a great diversity of tectonic movements (uplift vs. subsidence), which have guided the initiation and the evolution of LIG reefs described below.

The palaeo-relative sea level (RSL) has been reconstructed based on reported elevations of coral assemblages, tectonic movements and estimated palaeo-water-depth intervals of their modern counterparts, as shown in Fig. 14.

\subsection{French Polynesia}

LIG reef deposits have been reported from outcrops on several Polynesian islands and from drill cores collected on Moruroa and Bora Bora.

The first dates on LIG reef terraces from French Polynesia, which can be found at elevations of +4 to $+5 \mathrm{~m}$, were obtained by Veeh (1966), who dated in situ fossil corals from emerged Pleistocene reef terraces on Anaa, Niau and Makatea. Leptoria specimens at elevations of +2 to $+4 \pm 0.5 \mathrm{~m}$ MLWS on Anaa have been dated at $110 \pm 20$, $140 \pm 30$ and $150 \pm 40 \mathrm{ka}$ (WALIS U-series IDs 1731-1733; 

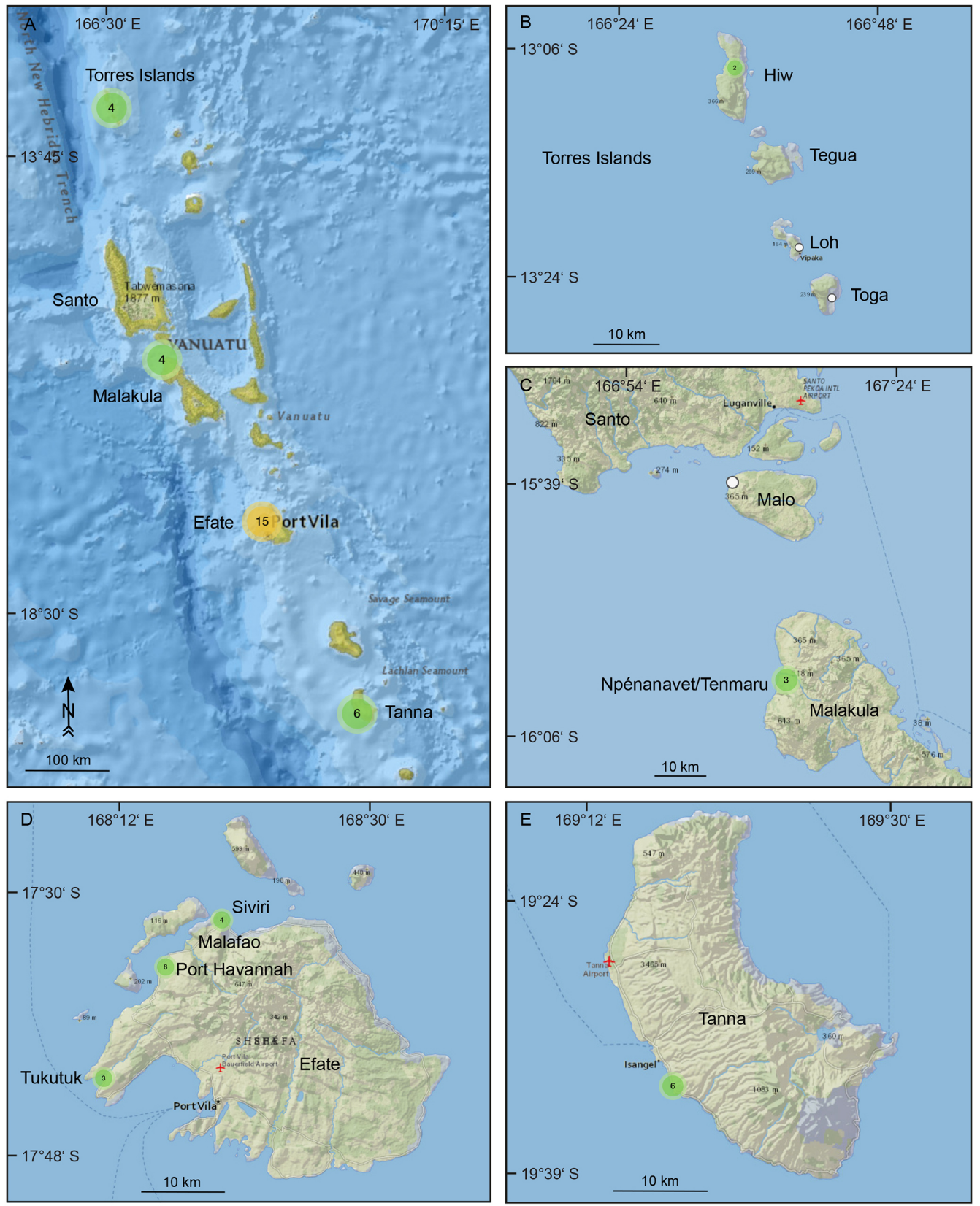

Figure 9. Map showing islands in Vanuatu considered in this article (green and orange circles). Study sites are indicated by white and green circles. Basemap: "National Geographic Map", with data from National Geographic, Esri, Garmin, HERE, UNEP-WCMC, USGS, NASA, ESA, METI, NRCAN, GEBCO, NOAA and INCREMENT P Corp.

ANAA5, ANAA15 and ANAA16). However, the use of the alpha-counting technique resulted in large age uncertainties.

Pirazzoli et al. (1988a) used electron spin resonance (ESR) to date the $4-5 \mathrm{~m}$ high raised reefs from Anaa (see Fig. 2 in Pirazzoli et al., 1988a). A Leptoria? coral colony in growth position with an aragonite content of $97 \%$ yielded an age of $109+8 /-4 \mathrm{ka}$ (WALIS ESR ID 103; 3AN14). The authors reported an elevation of $3.85 \pm 0.2 \mathrm{~m}$ above mean sea level (MSL) and a palaeo-MSL at an elevation of $+4.15 \pm 0.2 \mathrm{~m}$.
Modern Leptoria is living at a median and average depths of 4 and $7.5 \mathrm{~m}$, respectively (see Table 2). Consequently, the palaeo-RSL based on those four Leptoria specimen from Anaa is assumed to have been at $+8.75 \pm 2.3 \mathrm{~m}$ (WALIS RSL ID 548).

An emerged reef terrace at the same elevation has been dated by Veeh (1966) on Niau and Makatea. Two Leptoria specimens at hand-levelled elevations of +3 to $+4 \pm 0.5 \mathrm{~m}$ MLWS on Niau have been dated at $160 \pm 40 \mathrm{ka}$ 
Table 2. Modern depth distribution (in metres below mean sea level - MSL) of corals identified in LIG records from the tropical Pacific islands. This table is based on two databases: OBIS (Ocean Biodiversity Information System; https://obis.org, last access: 22 April 2021) and IUCN (International Union for Conservation of Nature; https://www.iucnredlist.org, last access: 22 April 2021).

\begin{tabular}{|c|c|c|c|c|c|c|}
\hline & \multicolumn{4}{|c|}{ OBIS database } & \multicolumn{2}{|c|}{ IUCN database } \\
\hline & Median depth & Average depth & Min depth & Max depth & Min depth & Max depth \\
\hline Acropora* & 4.0 & 5.7 & 0.0 & 91.0 & & \\
\hline Acropora aspera & 3.0 & 3.0 & 0.0 & 11.0 & 0.0 & 5.0 \\
\hline Acropora millepora & 3.0 & 3.9 & 0.0 & 12.0 & 2.0 & 12.0 \\
\hline Acropora pulchra & 3.0 & 4.0 & 0.0 & 18.0 & 1.0 & 20.0 \\
\hline Cyphastrea serailia & 4.5 & 5.2 & 0.0 & 24.9 & 0.0 & 50.0 \\
\hline Dipsastraea & 6.0 & 11.1 & 0.0 & 60.0 & & \\
\hline Dipsastraea laxa & 7.0 & 5.9 & 0.0 & 11.0 & 1.0 & 25.0 \\
\hline Gardineroseris planulata & 3.0 & 5.9 & 0.0 & 50.0 & 2.0 & 30.0 \\
\hline Goniastrea & 6.0 & 15.3 & 0.0 & 92.0 & & \\
\hline Goniastrea retiformis & 8.0 & 17.9 & 0.0 & 53.0 & 0.0 & 20.0 \\
\hline Goniastrea stelligera & 0.0 & 13.6 & 0.0 & 91.0 & 0.0 & 20.0 \\
\hline Leptastrea & 7.0 & 16.8 & 0.0 & 86.0 & & \\
\hline Leptoria & 4.0 & 7.5 & 0.0 & 86.0 & & \\
\hline Leptoria phrygia & 4.0 & 5.0 & 0.0 & 47.0 & 0.0 & 30.0 \\
\hline Oulophyllia crispa & 6.0 & 6.4 & 0.0 & 50.0 & 2.0 & 30.0 \\
\hline Platygyra & 4.0 & 6.9 & 0.0 & 84.0 & & \\
\hline Platygyra lamellina & 4.0 & 4.4 & 0.0 & 27.4 & 1.0 & 30.0 \\
\hline Platygyra sinensis & 5.0 & 5.0 & 0.0 & 17.0 & 0.0 & 30.0 \\
\hline Plesiastrea versipora & 6.0 & 5.8 & 0.0 & 30.0 & 1.0 & 40.0 \\
\hline Pocillopora & 0.0 & 15.6 & 0.0 & 142.0 & & \\
\hline Pocillopora meandrina & 0.0 & 15.8 & 0.0 & 98.0 & 1.0 & 27.0 \\
\hline Porites* & 0.0 & 18.5 & 0.0 & 142.0 & & \\
\hline Porites lobata & 0.0 & 19.2 & 0.0 & 98.0 & 0.0 & 30.0 \\
\hline Porites lutea & 0.0 & 2.7 & 0.0 & 84.0 & 0.0 & 30.0 \\
\hline
\end{tabular}

* Data for Indo-Pacific region only.

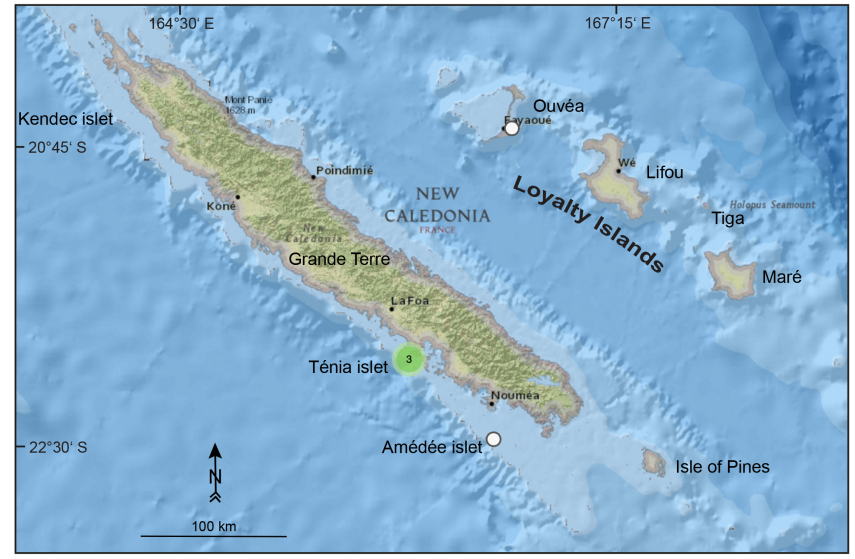

Figure 10. Map showing islands in New Caledonia considered in this article (green and white circles). Basemap: "National Geographic Map", with data from National Geographic, Esri, Garmin, HERE, UNEP-WCMC, USGS, NASA, ESA, METI, NRCAN, GEBCO, NOAA and INCREMENT P Corp.

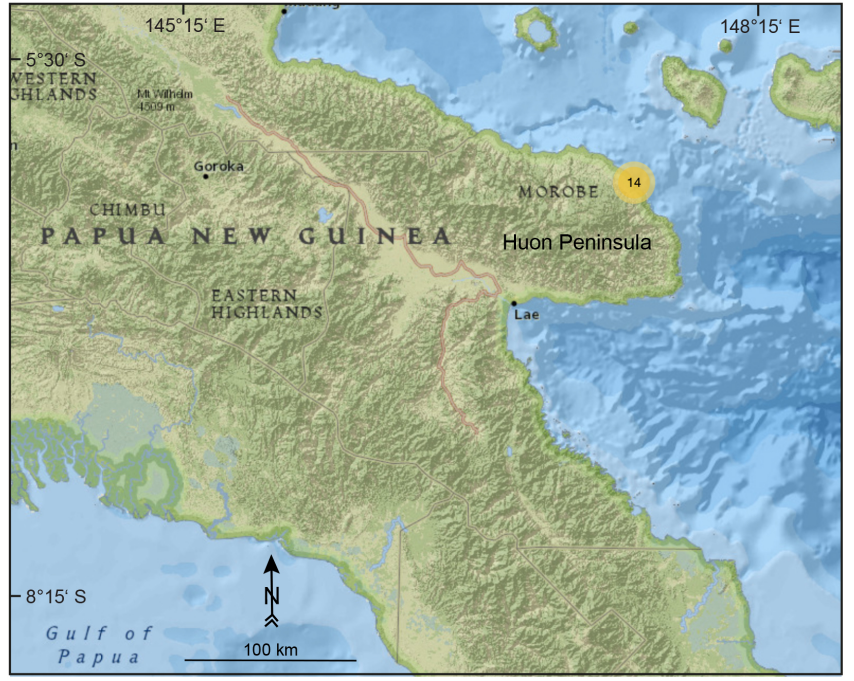

Figure 11. Map showing study sites on the Huon Peninsula, Papua New Guinea, considered in this article (orange circle). Basemap: "National Geographic Map", with data from National Geographic, Esri, Garmin, HERE, UNEP-WCMC, USGS, NASA, ESA, METI, NRCAN, GEBCO, NOAA and INCREMENT P Corp. 

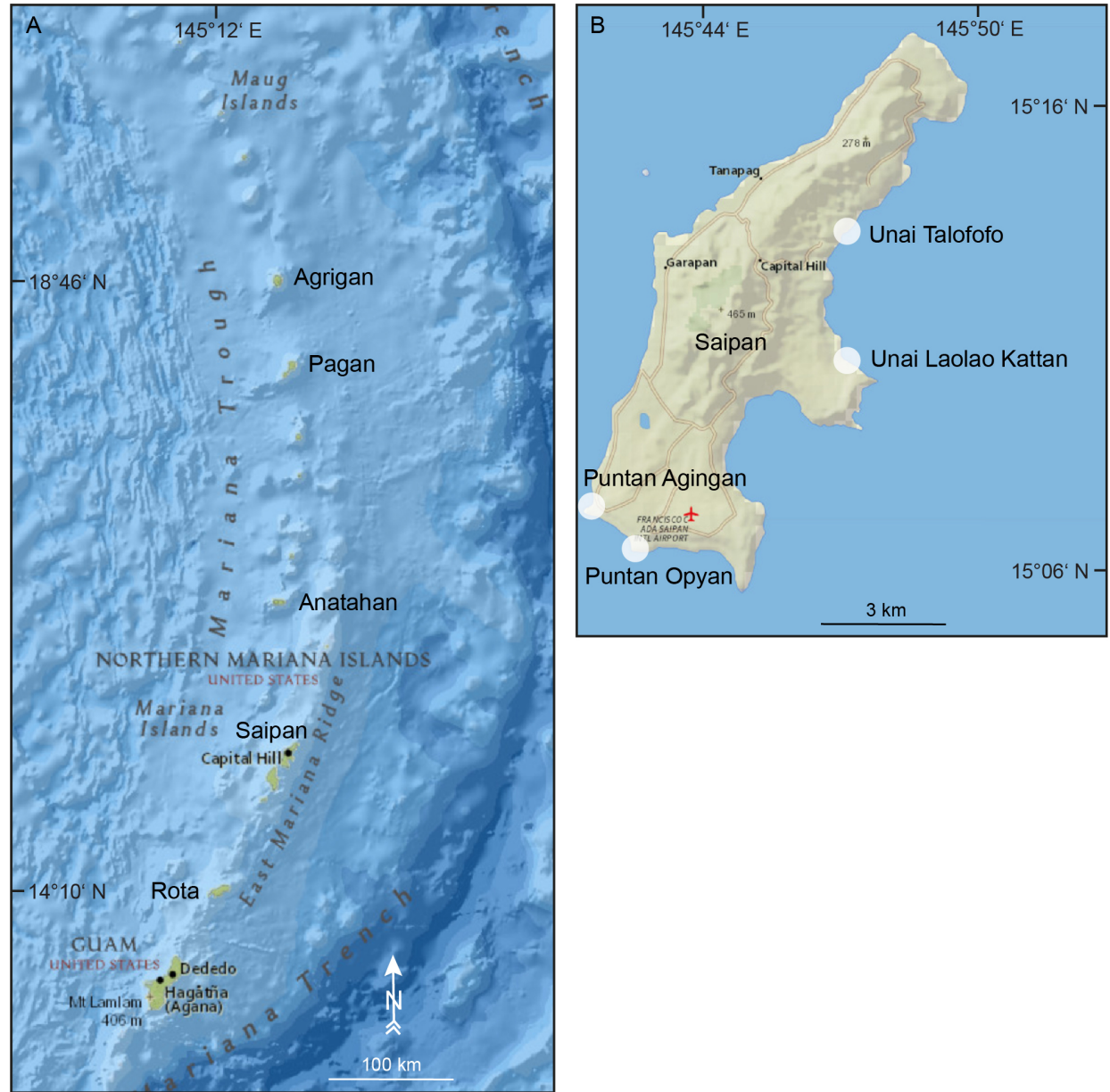

Figure 12. Map showing Guam and islands in the Northern Mariana Islands considered in this article. Study sites on Saipan are indicated by white circles. Basemap: "National Geographic Map", with data from National Geographic, Esri, Garmin, HERE, UNEP-WCMC, USGS, NASA, ESA, METI, NRCAN, GEBCO, NOAA and INCREMENT P Corp.

and $120 \pm 20 \mathrm{ka}$ (WALIS U-series IDs 1735 and 1736; NIAU4 and NIAU6). The palaeo-RSL on Niau is assumed to have been at $+9.25 \pm 2.0 \mathrm{~m}$ (WALIS RSL ID 549). Favia (now called Dipsastraea; Huang et al., 2014) and Leptoria on Makatea at an elevation of $+3 \pm 0.5 \mathrm{~m}$ MLWS have yielded ages of $140 \pm 30 \mathrm{ka}$ and $100 \pm 20 \mathrm{ka}$ (WALIS Useries IDs 1737-1738; MAKA2 and MAKA3). The palaeoRSL on Makatea is assumed to have been at $+8.75 \pm 1.8 \mathrm{~m}$ (WALIS RSL ID 550). Montaggioni and Camoin (1997) identified two well-defined Pleistocene terraces on Makatea, one of which is at an elevation of $+7 \mathrm{~m}$ and can be related to the $125 \mathrm{ka}$ RSL highstand. It can be assumed that Makatea reached relative vertical stability just prior to the $120 \mathrm{ka}$ marine transgression (Montaggioni et al., 1985; Montaggioni and Camoin, 1997).

LIG reef deposits have been reported in drill cores collected in Moruroa (Camoin et al., 2001) and Bora Bora (Gischler et al., 2016). The reef units related to the LIG in Moruroa drill cores (see Figs. 15 and 2 in Braithwaite and
Camoin, 2011) are mainly composed of coralgal frameworks built by an Acropora gr. danai-robusta/Porolithon onkodes assemblage, which typifies a very shallow depositional environment (i.e. shallower than $6 \mathrm{~m}$ ). However, only one out of six datings has been accepted (Camoin et al., 2001) and concerns a reworked colony of Acropora specimen at $92.7 \mathrm{~m}$ below MSL yielding an age of $124.4 \pm 2 \mathrm{ka}$ (WALIS U-series IDs 1017-1022; WALIS RSL ID 551; core FIL 5/30 at depth of $92.7 \mathrm{~m})$. The subsidence rate of Moruroa has been estimated at $0.007-0.008 \mathrm{~mm} / \mathrm{yr}$ (Camoin et al., 2001), i.e. about $1 \mathrm{~m}$ since $125 \mathrm{ka}$.

Gischler et al. (2016) dated a barrier reef drill core from Bora Bora. Core TEV1 was drilled at MSL, and a Pocillopora specimen at $30.6 \pm 0.6 \mathrm{~m}$ below MSL has given an age of $116.9 \pm 1.1 \mathrm{ka}$ (WALIS U-series ID 1869; TEV1). This sample is $100 \%$ aragonitic and the dating is considered reliable. The subsidence rate of Bora Bora has been estimated at 0.05 to $0.14 \mathrm{~mm} / \mathrm{yr}$. 

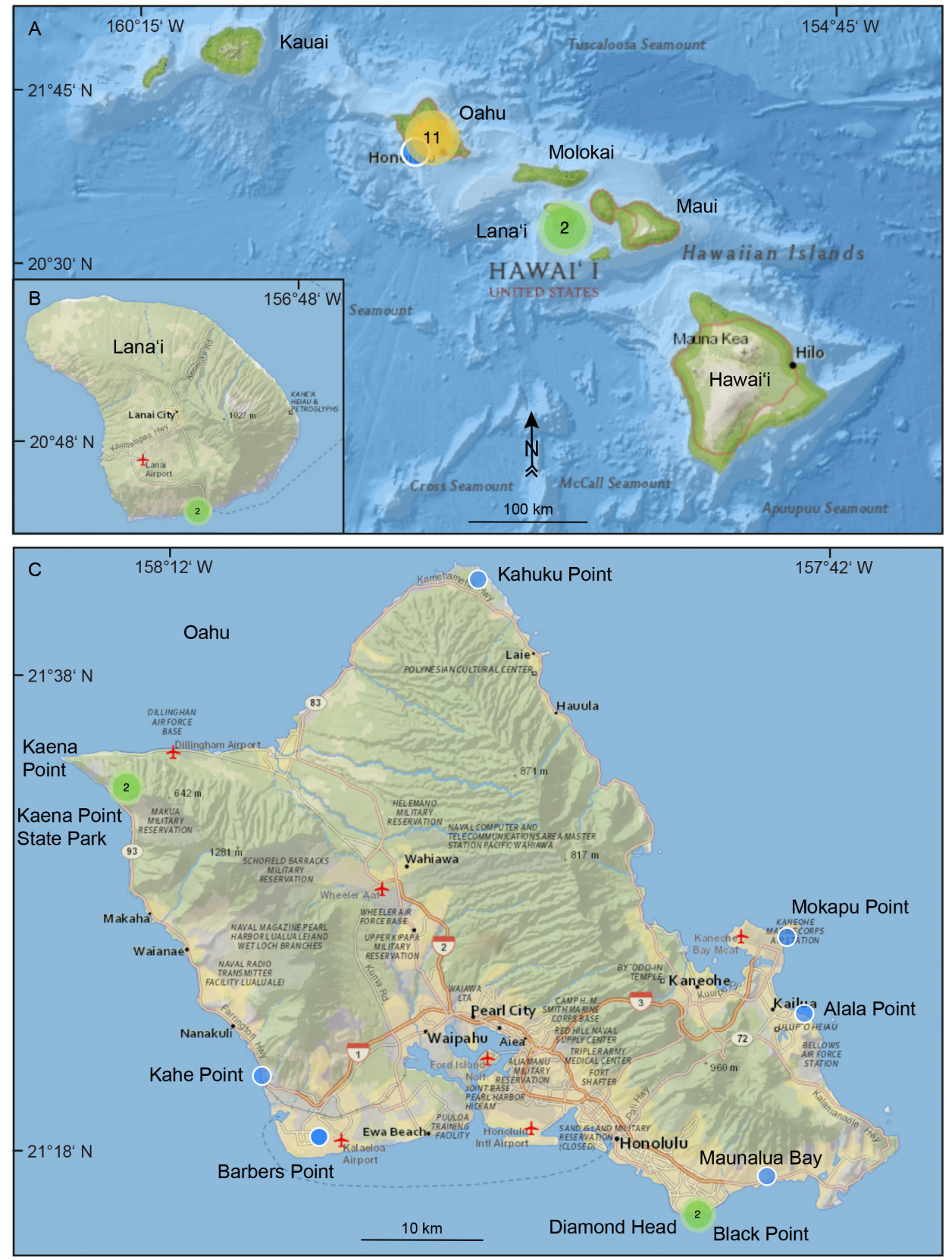

Figure 13. Map showing islands in Hawaii considered in this article (green and orange circles). Study sites on Lanai and Oahu are indicated by blue and green circles. Basemap: "National Geographic Map", with data from National Geographic, Esri, Garmin, HERE, UNEP-WCMC, USGS, NASA, ESA, METI, NRCAN, GEBCO, NOAA and INCREMENT P Corp.

In a recent study by Montaggioni et al. (2019a) a "eustatic sea level" of about $7 \mathrm{~m}$ above MSL during MIS 5e has been considered on Takapoto, but no U-series age has been reported.

\subsection{Cook Islands}

LIG reef deposits have been reported from outcrops on several southern Cook Islands and from drill cores collected on Pukapuka, northern Cook Islands.

The southern Cook Islands have been located in a complex tectonic setting related to volcanic processes since $1.65 \mathrm{Ma}$, the mean age for the main shield-building phase (Te Manga) on Rarotonga (Thompson et al., 1998; Neal and Trewick, 
Table 3. Measurement techniques used to establish the elevation of MIS 5e shorelines in the tropical Pacific islands.

\begin{tabular}{|c|c|c|}
\hline $\begin{array}{l}\text { Measurement } \\
\text { technique }\end{array}$ & Description & Typical accuracy \\
\hline $\begin{array}{l}\text { Total station or } \\
\text { Auto/hand level }\end{array}$ & $\begin{array}{l}\text { Total stations or levels measure slope distances from the instrument to } \\
\text { a particular point and triangulate relative to the } X Y Z \text { coordinates of the } \\
\text { base station. The accuracy of this process depends on how well defined } \\
\text { the reference point and on the distance of the surveyed point from the } \\
\text { base station. Thus, it is necessary to benchmark the reference station } \\
\text { with a nearby tidal datum, or use a precisely (DGPS) known geode- } \\
\text { tic point. The accuracy of the elevation measurement is also inversely } \\
\text { proportional to the distance between the instrument and the point being } \\
\text { measured. }\end{array}$ & $\begin{array}{l} \pm 0.1 / \pm 0.2 \mathrm{~m} \text { for total station } \\
\pm 0.2 / \pm 0.4 \mathrm{~m} \text { for hand level }\end{array}$ \\
\hline Theodolite and rod & Elevation derived from triangulation with a theodolite. & $\begin{array}{l}\text { Usually very precise, centimet- } \\
\text { ric accuracy, depending on dis- } \\
\text { tance }\end{array}$ \\
\hline $\begin{array}{l}\text { Barometric } \\
\text { altimeter }\end{array}$ & $\begin{array}{l}\text { Difference in barometric pressure between a point of known elevation } \\
\text { (often sea level) and a point of unknown elevation. Not accurate and } \\
\text { used only rarely in sea-level studies. }\end{array}$ & $\begin{array}{l}\text { Up to } \pm 20 \% \text { of elevation mea- } \\
\text { surement }\end{array}$ \\
\hline $\begin{array}{l}\text { Cross section from } \\
\text { publication }\end{array}$ & $\begin{array}{l}\text { The elevation was extracted from a published sketch/topographic sec- } \\
\text { tion. }\end{array}$ & $\begin{array}{l}\text { Variable, depending on the } \\
\text { scale of the sketch or } \\
\text { topographic section }\end{array}$ \\
\hline Metered tape or rod & $\begin{array}{l}\text { The end of a tape or rod is placed at a known elevation point, and the } \\
\text { elevation of the unknown point is calculated using the metered scale } \\
\text { and, if necessary, clinometers to calculate angles. }\end{array}$ & $\begin{array}{l}\text { Up to } \pm 10 \% \text { of elevation mea- } \\
\text { surement }\end{array}$ \\
\hline $\begin{array}{l}\text { Distance from top } \\
\text { of drill core }\end{array}$ & Distance from the top of drill core. & $\begin{array}{l}\text { Depending on coring technique } \\
\text { and sampling procedures }\end{array}$ \\
\hline Differential GPS & $\begin{array}{l}\text { GPS positions acquired in the field and corrected either in real time or } \\
\text { during post-processing with respect to the known position of a base sta- } \\
\text { tion or a geostationary satellite system (e.g. OmniSTAR). Accuracy de- } \\
\text { pends on satellite signal strength, distance from base station and number } \\
\text { of static positions acquired at the same location. }\end{array}$ & $\begin{array}{l} \pm 0.02 / \pm 0.08 \mathrm{~m} \text {, depending on } \\
\text { survey conditions and instru- } \\
\text { ments used (e.g. single-band vs. } \\
\text { dual-band receivers) }\end{array}$ \\
\hline Not reported & $\begin{array}{l}\text { The elevation measurement technique was not reported, most probably } \\
\text { hand level or metered tape. }\end{array}$ & $\begin{array}{l}20 \% \text { of the original elevation } \\
\text { reported added in root mean } \\
\text { square to the sea-level datum } \\
\text { error }\end{array}$ \\
\hline
\end{tabular}

2008). The formation of this volcanic system led to the subsidence of some islands (Rarotonga, Aitutaki and Manuae) and the subsequent uplift of other islands related to a flexural response to loading of the ocean floor (McNutt and Menard, 1978). However, this flexural response has been the subject of many debates and controversies regarding its course, timing and amplitude (see review in Woodroffe et al., 1991).

Gray et al. (1992) reported an average subsidence rate of 0.03 to $0.06 \mathrm{~mm} / \mathrm{yr}$ for the Cook Islands, resulting in a subsidence of up to $7.5 \mathrm{~m}$ since $125 \mathrm{ka}$. In contrast, uplift rates have been estimated at approximately $0.044 \mathrm{~mm} / \mathrm{yr}$ on Mangaia, $0.011 \mathrm{~mm} / \mathrm{yr}$ on Atiu, and $0.005-0.007 \mathrm{~mm} / \mathrm{yr}$ on Mitiaro and Mauke (Spencer et al., 1988). Uplift rates over the last $120 \mathrm{kyr}$ have been estimated at $0.07-0.10,0.05,0.03$ and $0.03-0.05 \mathrm{~mm} / \mathrm{yr}$ for Mangaia, Atiu, Mitiaro and Mauke, re- spectively, based on a $6 \mathrm{~m}$ sea-level highstand during the LIG (Woodroffe et al., 1991). These rates would imply an uplift of these islands of about 3.6 to $12 \mathrm{~m}$ since $120 \mathrm{ka}$. Conversely, a subsidence rate of $0.02 \mathrm{~mm} / \mathrm{yr}$ has been considered for Rarotonga (Woodroffe et al., 1991). However, it is uncertain whether the assumed $6 \mathrm{~m} \mathrm{LIG} \mathrm{sea-level} \mathrm{highstand} \mathrm{for} \mathrm{the}$ Cook Islands is appropriate.

Gray et al. (1992) reported a subsidence rate of $0.045 \pm 0.028 \mathrm{~mm} / \mathrm{yr}$ for Pukapuka in the northern Cook Islands.

Exposed reef terraces can be found at different elevations, up to $15 \mathrm{~m}$ above MSL, on different southern Cook Islands, including Mangaia, Rarotonga, Atiu, Mauke and Mitiaro. The first datings of LIG reef limestones in the southern Cook Islands have been provided by Veeh (1966). He dated in situ 
Table 4. Sea-level datums reviewed in this study. $\mathrm{n} / \mathrm{a}$ - not applicable

\begin{tabular}{|c|c|c|}
\hline Datum name & Datum description & Datum uncertainty \\
\hline Mean sea level/general definition & $\begin{array}{l}\text { General definition of MSL, with no indications on the } \\
\text { datum to which it is referred to. }\end{array}$ & $\begin{array}{l}\text { A datum uncertainty } \\
\text { can be established on a } \\
\text { case-by-case basis. }\end{array}$ \\
\hline Modern reef & Upper surface of modern reef. & $\begin{array}{l}\text { A datum uncertainty } \\
\text { may be established on a } \\
\text { case-by-case basis. }\end{array}$ \\
\hline Mean high tide (MHT) & $\begin{array}{l}\text { From NOAA definitions: "It is obtained by subtracting } \\
\text { the mean of all the high waters from the mean of the } \\
\text { higher high waters. One-half the average difference be- } \\
\text { tween the two low waters of each tidal day observed } \\
\text { over the National Tidal Datum Epoch." }\end{array}$ & $\begin{array}{l}\text { Depending on the qual- } \\
\text { ity of tidal data used. }\end{array}$ \\
\hline Mean low tide (MLT) & $\begin{array}{l}\text { From http://tideschart.com (last access: } 22 \text { April 2021): } \\
\text { "The Mean Low Tide (or Mean Low Water) is the av- } \\
\text { erage height of all low tides in a given place, deriving } \\
\text { from a long series of observations (NTDE) of all levels } \\
\text { of low tide in that spot." }\end{array}$ & $\begin{array}{l}\text { Depending on the qual- } \\
\text { ity of tidal data used. }\end{array}$ \\
\hline Mean low water springs (MLWS) & $\begin{array}{l}\text { From http://www.coastalwiki.org (last access: } 22 \text { April } \\
\text { 2021): "The height of mean low water springs is the av- } \\
\text { erage throughout a year of the heights of two successive } \\
\text { low waters during those periods of } 24 \mathrm{~h} \text { (approximately } \\
\text { once a fortnight) when the range of the tide is greatest." }\end{array}$ & $\begin{array}{l}\text { Depending on the qual- } \\
\text { ity of tidal data used. }\end{array}$ \\
\hline Not reported & $\begin{array}{l}\text { The sea-level datum is not reported and impossible to } \\
\text { derive from metadata. }\end{array}$ & $\mathrm{n} / \mathrm{a}$ \\
\hline
\end{tabular}
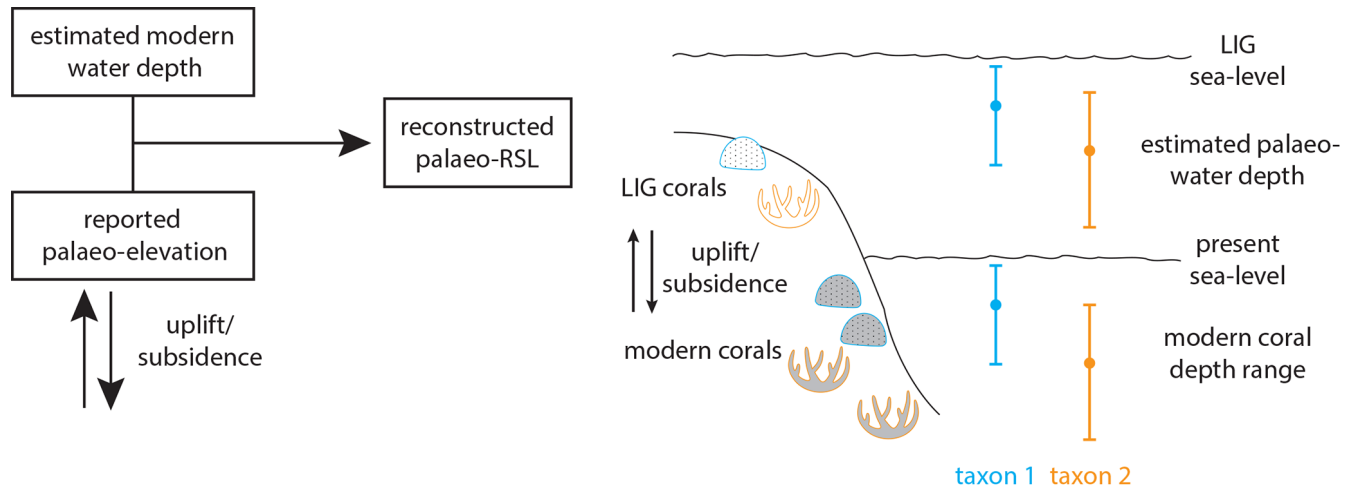

Figure 14. Reconstruction of palaeo-relative sea level (RSL) based on reported palaeo-elevations of last interglacial (LIG) corals and estimated palaeo-water-depth intervals of their modern counterparts. The range bars indicate maximum, median and minimum depths. Modern corals are shown in grey and LIG corals in white.

fossil corals from emerged Pleistocene reef terraces on Mangaia using the alpha-counting technique. Two corals, Favia (now called Dipsastraea; Huang et al., 2014) and Leptoria, at a hand-levelled elevation of $+2 \pm 0.5 \mathrm{~m}$ MLWS have been dated at $90 \pm 20$ and $110 \pm 20 \mathrm{ka}$, respectively (WALIS Useries IDs 1744 and 1746; MANG1 and MANG2; WALIS RSL ID 585). Modern Leptoria live at median and average depths of 4 and $7.5 \mathrm{~m}$, respectively; however, their depth range is large, from the surface down to more than $80 \mathrm{~m}$ (see
Table 2). Spencer et al. (1988) dated four Porites samples from an encrusting groove wall on Mangaia using the alphacounting technique. All samples contained less than $1 \%$ of calcite, and all datings have been accepted. The four samples at elevations of $+15,+11,+3$ and +13 m MLT have been dated at $118 \pm 12,107 \pm 18,101 \pm 12$ and $135 \pm 15 \mathrm{ka}$, respectively (WALIS U-series IDs 1848 and 1850-1852; M2, M3, M47 and M54; $1 \sigma$ uncertainty; WALIS RSL ID 584; see Fig. 16). The tidal range is approximately $80 \mathrm{~cm}$; i.e. the sam- 


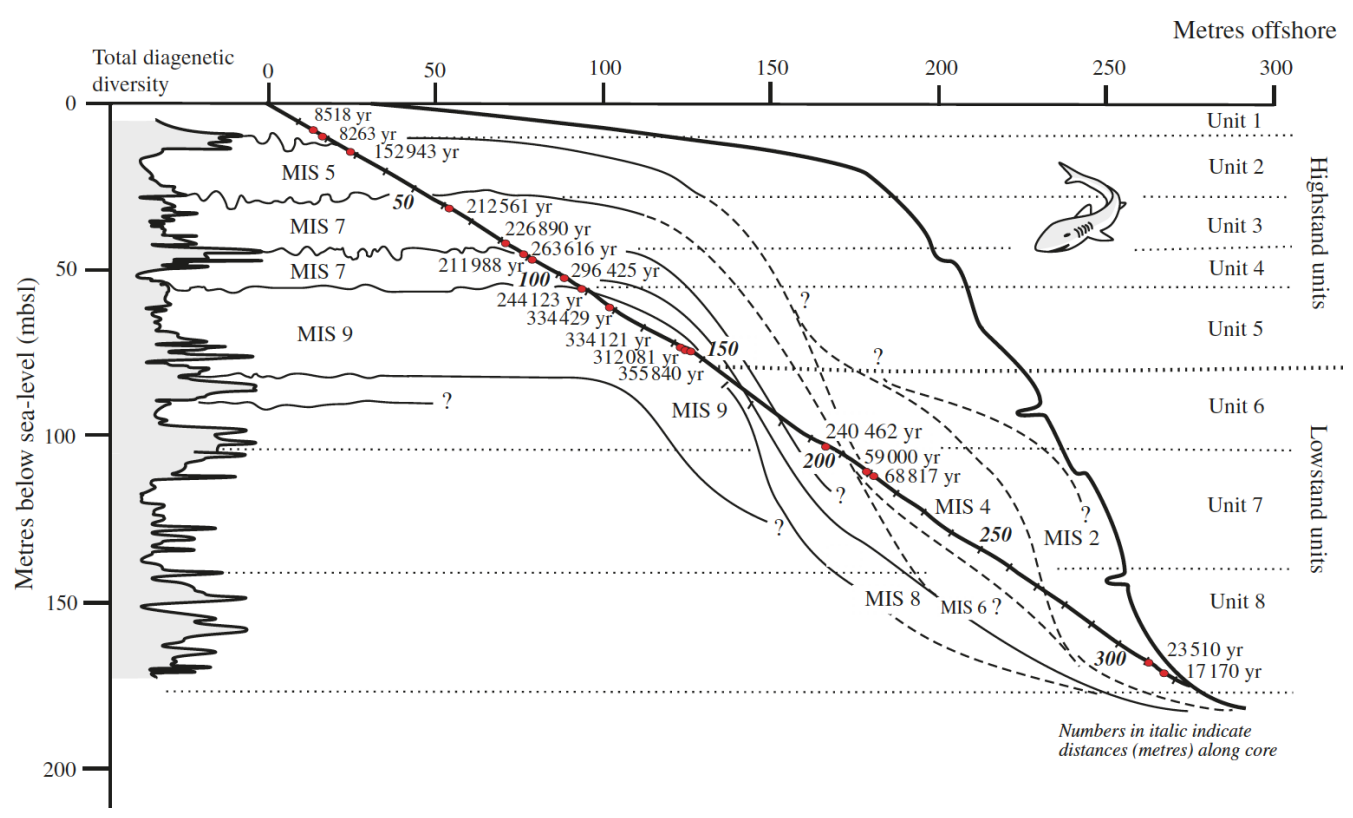

Figure 15. Distribution of radiometric ages and reconstruction of successive reef units (MIS: Marine Isotopic Stages) in Moruroa cores FIL 8/30 and 8/40 (from Camoin et al., 2001, and Braithwaite and Camoin, 2011).

ple elevations are of $+15.4,+11.4,+3.4$ and +13.4 MSL. Porites lives at median and average depths of 0 and $18.5 \mathrm{~m}$, respectively, in modern environments; however, this genus displays a wide depth range, from the surface down to more than $100 \mathrm{~m}$ (see Table 2).

Stoddart et al. (1985) presumed the occurrence of LIG reefs on Rarotonga, southern Cook Islands, at a maximum elevation of $3.5 \mathrm{~m}$ above MSL. They assumed that these reefs have not been tectonically uplifted.

Spencer et al. $(1987,1988)$ identified deposits of probable Late Pleistocene age at $+12.2 \mathrm{~m}$ on Atiu, $+10.0 \mathrm{~m}$ on Mauke and $+9.8 \mathrm{~m}$ on Mitiaro in the southern Cook Islands. Stoddart et al. (1990) found evidence of late Pleistocene RSL up to $+12.2 \mathrm{~m}$ on Atiu, $+10.0 \mathrm{~m}$ on Mauke and $+9.8 \mathrm{~m}$ on Mitiaro. They also reported unconformities within the Pleistocene at +1.75 to $+2.65 \mathrm{~m}$ on Atiu, +1.5 to $+2.75 \mathrm{~m}$ on Mauke and +4.1 to $+6.0 \mathrm{~m}$ on Mitiaro. Woodroffe et al. (1991) identified MIS 5e reefs on Atiu, Mauke and Mitiaro using the alpha-counting technique. Three samples from Atiu have been dated (WALIS U-series IDs 1812-1817; AT8, AT9 and AT11; see Fig. 17): (1) an in situ Porites on an erosional bench at an elevation of less than $+2.7 \mathrm{~m}$ MLT (interpreted elevation $+1.5 \pm 1.5 \mathrm{~m} \mathrm{MSL}$ ) with an age of $132 \pm 10$ and $111 \pm 7 \mathrm{ka}$ (WALIS U-series IDs 1812 and 1813; AT8; WALIS RSL ID 557); (2) a Porites colony from the encrusting upper unit at an elevation of more than $+2.7 \mathrm{~m}$ MLT (interpreted elevation $+6.5 \pm 3.5 \mathrm{~m} \mathrm{MSL}$ ) with an age of $135 \pm 10$ and $151 \pm 12 \mathrm{ka}$ (WALIS U-series IDs 1814 and 1815; AT9; WALIS RSL ID 558); and (3) a massive in situ coral on the cliff top at an elevation of +10 to $+12 \mathrm{~m}$ MLT (interpreted elevation $+11 \pm 1 \mathrm{~m} \mathrm{MSL}$ ) with an age of $111 \pm 6$ and $113 \pm 9 \mathrm{ka}$ (WALIS U-series IDs 1816 and 1817; AT11; WALIS RSL ID 559).

Woodroffe et al. (1991) also dated four samples from Mauke (see Fig. 18): (1) a Porites colony from a perched reef block at an elevation of +7 to $+8 \mathrm{~m}$ MLT (interpreted elevation $+7.5 \pm 1 \mathrm{mMSL}$ ) with an age of $136 \pm 10$ and $138 \pm 10 \mathrm{ka}$ (WALIS U-series IDs 1818 and 1819; MK9; WALIS RSL ID 560); (2) an encrusting coral from the upper unit at an elevation of more than $+2 \mathrm{~m}$ MLT (interpreted elevation $+3 \pm 1 \mathrm{~m} \mathrm{MSL}$ ) with an age of $123 \pm 8$ and $138 \pm 12 \mathrm{ka}$ (WALIS U-series IDs 1820 and 1821; MK15; WALIS RSL ID 561); (3) a Porites colony from the encrusting upper unit at an elevation of $+5 \mathrm{~m}$ MLT (interpreted elevation $+5 \pm 1 \mathrm{~m} \mathrm{MSL}$ ) with an age of $136 \pm 11$ and $145 \pm 10 \mathrm{ka}$ (WALIS U-series IDs 1822 and 1823; MK16; WALIS RSL ID 561); and (4) a Porites boulder in the upper unit at an elevation of $+6 \mathrm{~m}$ MLT (interpreted elevation $+6 \pm 1 \mathrm{~m} \mathrm{MSL}$ ) with an age of $119 \pm 8$ and $119 \pm 7 \mathrm{ka}$ (WALIS U-series IDs 1824 and 1825; MK18; WALIS RSL ID 561). Porites lives at median and average depths of 0 and $18.5 \mathrm{~m}$, respectively, in modern environments; however, this genus displays a wide depth range (see Table 2).

Five samples from Mitiaro (see Fig. 19) have been dated by Woodroffe et al. (1991): (1) two specimens of Faviidae (now called Merulinidae; Huang et al., 2014) from Te Unu at an elevation of more than $+4 \mathrm{~m}$ (interpreted elevation $+6.5 \pm 2.5 \mathrm{~m} \mathrm{MSL}$ ) have been dated at $128 \pm 6,140 \pm 10$, $98.1 \pm 5.4,112 \pm 7$ and $132 \pm 9 \mathrm{ka}$ (WALIS U-series IDs 1826-1830; MT1 and MT2; WALIS RSL ID 580); Merulinidae mainly indicate a depth range of $0-30 \mathrm{~m}$; (2) one Plesiastrea specimen from the north coast at an elevation of 

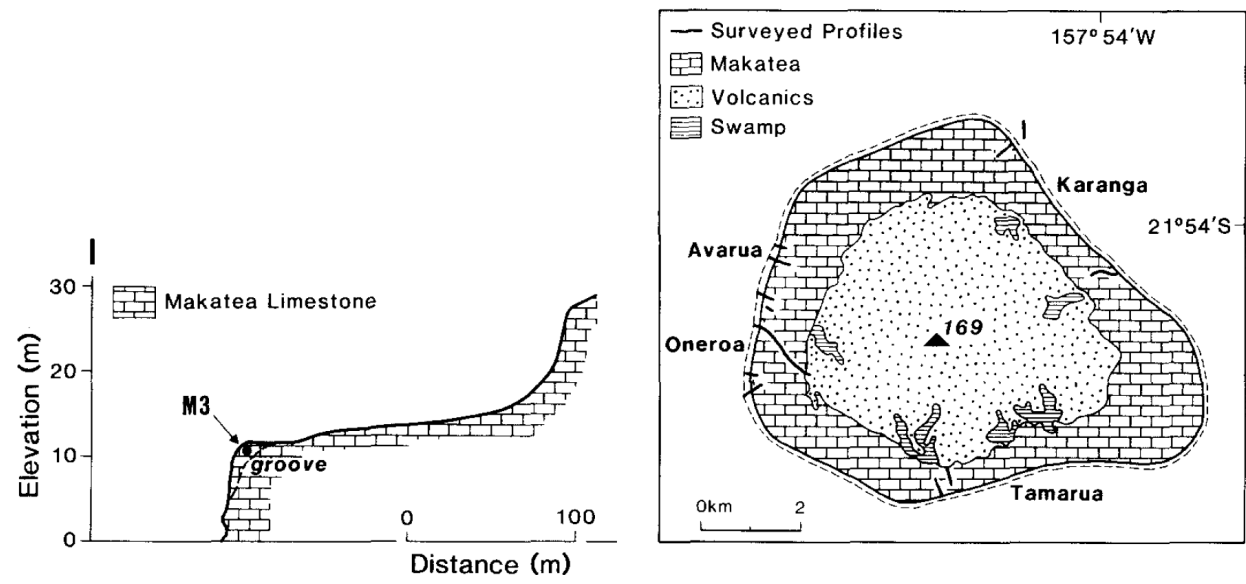

Figure 16. Sea-level indicators on Mangaia, Cook Islands. Selected profiles and dated samples are shown (from Woodroffe et al., 1991).
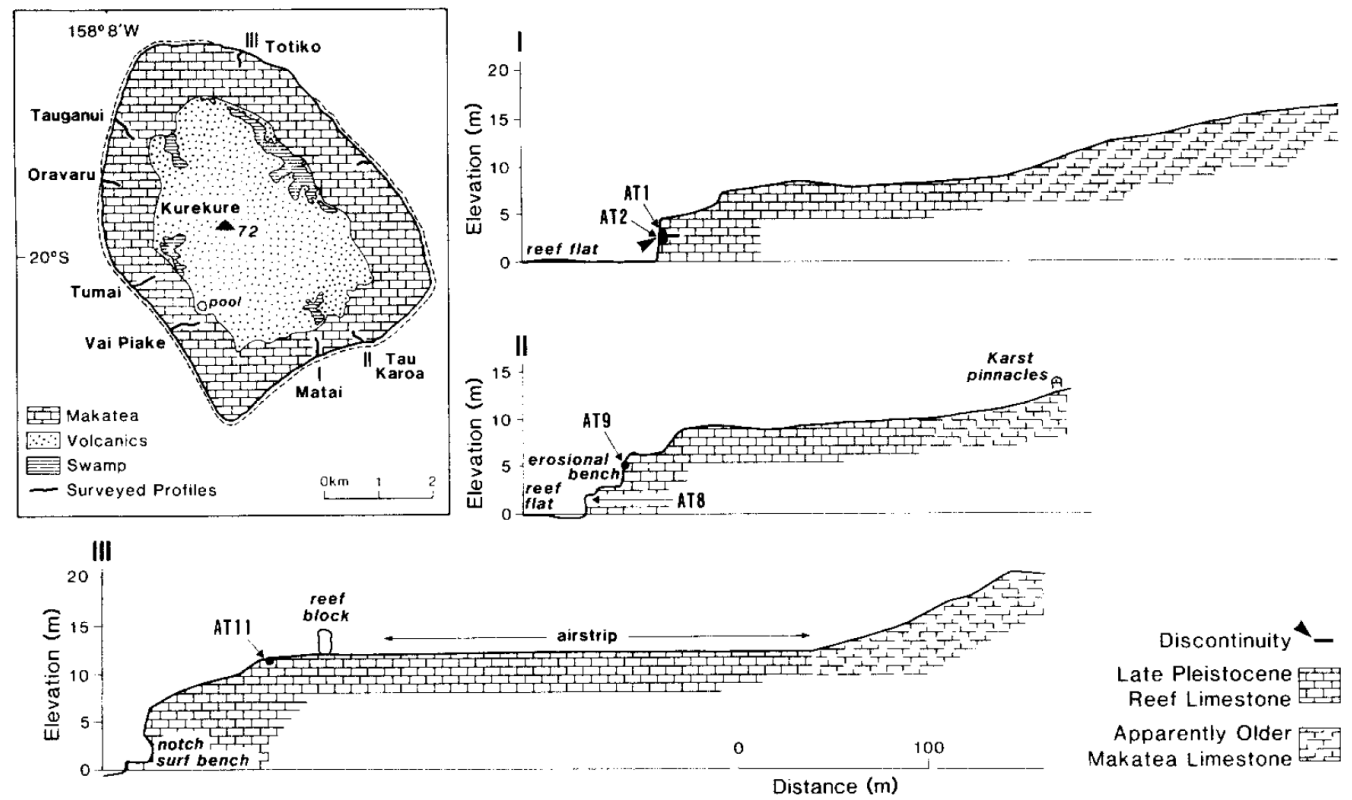

Figure 17. Sea-level indicators on Atiu, Cook Islands. Selected profiles and dated samples are shown (from Woodroffe et al., 1991).

more than $+4 \mathrm{~m}$ (interpreted elevation $+6.5 \pm 2.5 \mathrm{~m} \mathrm{MSL}$ ) has been dated at $120 \pm 6$ and $132 \pm 9 \mathrm{ka}$ (WALIS U-series IDs 1832 and 1834; MT9; WALIS RSL ID 581); in modern reef environments, Plesiastrea mainly lives at depths ranging from the surface down to $10 \mathrm{~m}$; (3) one Porites specimen from the village at an elevation of more than $+2 \mathrm{~m}$ (interpreted elevation $+5.5 \pm 3.5 \mathrm{~m} \mathrm{MSL}$ ) has yielded ages of $116 \pm 8,144 \pm 9$ and $106.3 \pm 5.4 \mathrm{ka}$ (WALIS U-series IDs 1836-1838; MT13; WALIS RSL ID 582); and (4) one Porites specimen from Vaikoua at an elevation of more than $+3 \mathrm{~m}$ (interpreted elevation $+4 \pm 1 \mathrm{~m} \mathrm{MSL}$ ) revealed an age of $118 \pm 7$ (WALIS U-series IDs 1841 and 1842; MT15; WALIS RSL ID 583). Porites lives at median and average depths of 0 and $18.5 \mathrm{~m}$, respectively, in modern environments; however, this genus displays a wide depth range (see
Table 2). All samples contained less than $1 \%-2 \%$ of calcite, and all datings have been accepted ( $1 \sigma$ uncertainty). Elevations have been hand-levelled, and the tidal range is approximately $80 \mathrm{~cm}$.

Gray et al. (1992) extracted drill cores and described widespread LIG reefs on Pukapuka (see Fig. 3 in Gray et al., 1992); however, they only obtained reliable ages on two Porites specimens (100\% aragonite; WALIS RSL ID 586). Electron spin resonance (ESR) dating provided two ages of $144 \pm 22$ and $136 \pm 20 \mathrm{ka}$ for samples at depths of 21.77 and $24.85 \mathrm{~m} \mathrm{MSL}$, respectively (WALIS ESR IDs 104 and 105; 991 and 951). The Porites specimen at a depth of $24.85 \mathrm{~m}$ MSL was also dated using the alpha-counting technique, which revealed an age of $130 \pm 9 \mathrm{ka}$ (WALIS U-series ID $1855,1 \sigma$ uncertainty; 951). Porites lives at median and 

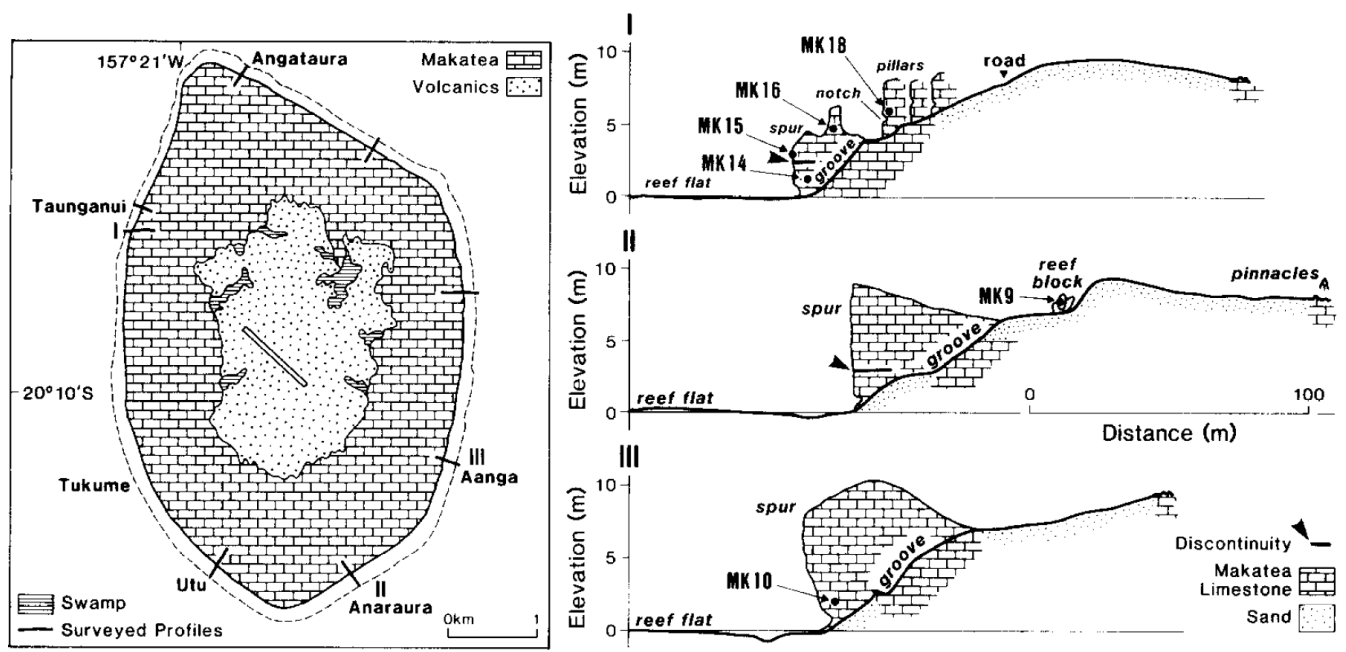

Figure 18. Sea-level indicators on Mauke, Cook Islands. Selected profiles and dated samples are shown (from Woodroffe et al., 1991).
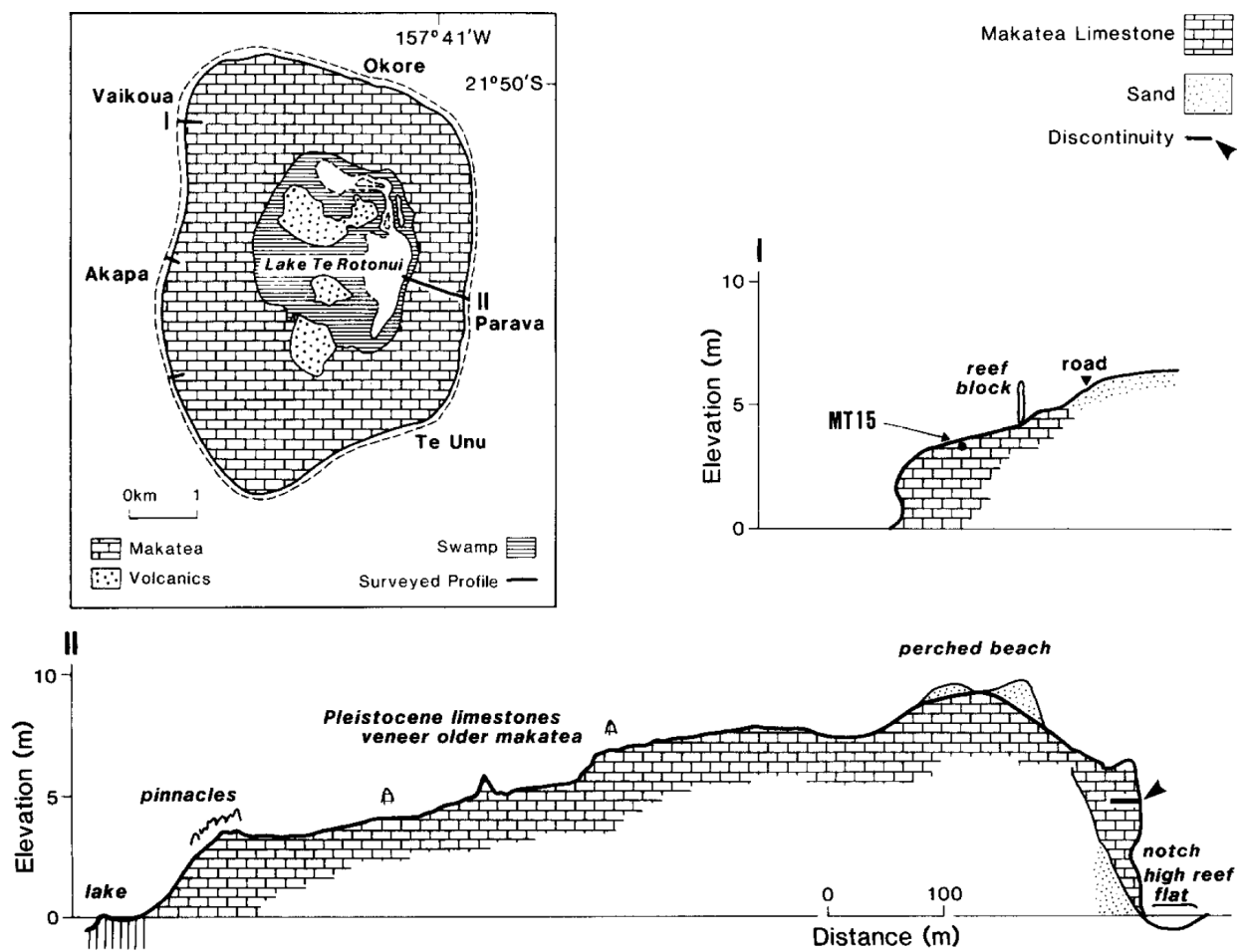

Figure 19. Sea-level indicators on Mitiaro, Cook Islands. Selected profiles and dated samples are shown (from Woodroffe et al., 1991).

average depths of 0 and $18.5 \mathrm{~m}$, respectively in modern environments.

Most of the dated samples from the southern Cook Islands by Woodroffe et al. (1991) can be related to the LIG RSL highstand, but a MIS 7 reef, i.e. the penultimate interglacial, has also been observed (see Fig. 20). Woodroffe et al. (1991) did not observe two periods of high RSL separated by a period of lower RSL during the LIG. However, they describe several stratigraphic features, such as erosional benches and notches, that might indicate RSL fluctuations during MIS 5e.
Overall, the large variability in elevations and the lack of accurate ages from the Cook Islands do not allow any precise conclusion about the LIG RSL.

\subsection{Samoa}

Exposed Pleistocene reef terraces have been described on several Samoan Islands, but no dates have been reported in the reviewed studies. Kear and Wood (1959) reported terraces occurring at up to 15 and $10 \mathrm{~m}$ higher than present RSL 


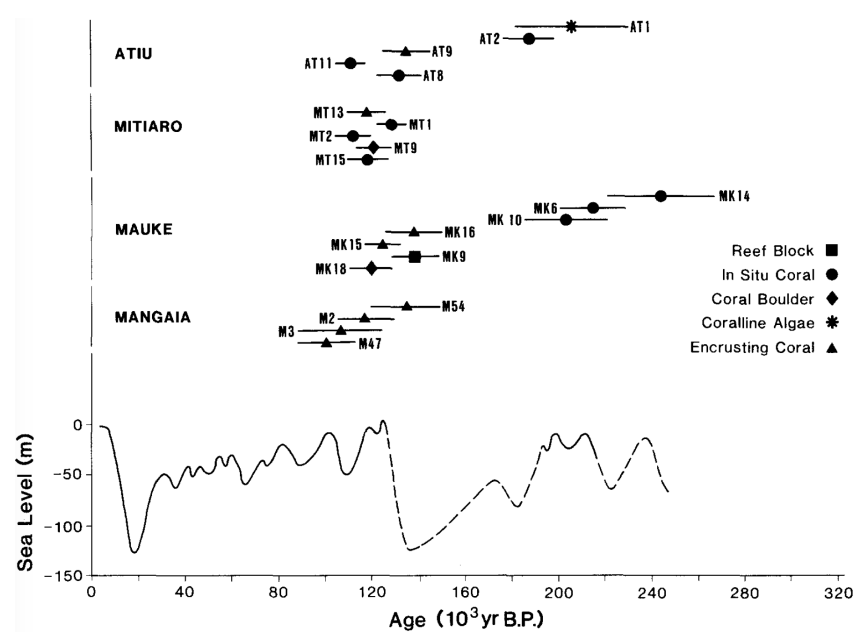

Figure 20. Uranium-series ages ( \pm 1 standard error) from corals of the southern Cook Islands, and comparison with the late Quaternary sea-level curve of Chappell and Shackleton (1986) (from Woodroffe et al., 1991).

on Upolu and Upolu's offshore islands, respectively, and that might correspond to the LIG period $(125 \mathrm{ka})$. They also described benches near Fagaloa Bay at elevations of +39 to $+60 \mathrm{~m}$, which might relate to the LIG or penultimate interglacial.

Stice and McCoy (1968) observed cliffs with benches at elevations of 4.5 to $1.5 \mathrm{~m}$ above MSL, probably indicating former higher RSL on three Manu'a Islands. The +3.7 to $+3.0 \mathrm{~m}$ terrace is composed of sand and coral shingle or entirely of sand.

\subsection{Nive}

LIG reef deposits have been dated from outcrops by Kennedy et al. (2012). The earliest studies by Agassiz (1903), David (1904) and Schofield (1959) described different raised reef terraces on Niue. The widest terrace (Alofi Terrace; see Figs. 21 and 22) is the most continuous one around the island (Agassiz, 1903). David (1904) recognized three terraces at $+6,+24$ to +27 and $+60 \mathrm{~m}$ and also mentioned a terrace at an elevation of $40 \mathrm{~m}$ above MSL. Schofield (1959) distinguished the Alofi Terrace at about $+23 \mathrm{~m}$ and the $\mathrm{Mu}$ talau Platform, a $+69 \mathrm{~m}$ high terrace, and identified five more terraces, including two submerged ones at -37 to -33 and -15 to $-11 \mathrm{~m}$ and three exposed ones at +12 to $+14,+35$ to +40 and at $+55 \mathrm{~m}$. At least parts of the Alofi Terrace date to 230-260 ka (Wheeler, 2000). The Alofi Terrace is overlain by a $6 \mathrm{~m}$ thick LIG reef sequence (Paulay, 1988; Paulay and Spencer, 1992; Spencer and Paulay, 1994; Wheeler, 2000). Beach deposits and erosional features indicate a $6 \mathrm{~m}$ high RSL (Paulay and Spencer, 1992). More recent studies describe the different terraces on Niue from close to present MSL up to an elevation of $+60 \mathrm{~m}$ (Terry and Nunn, 2003;

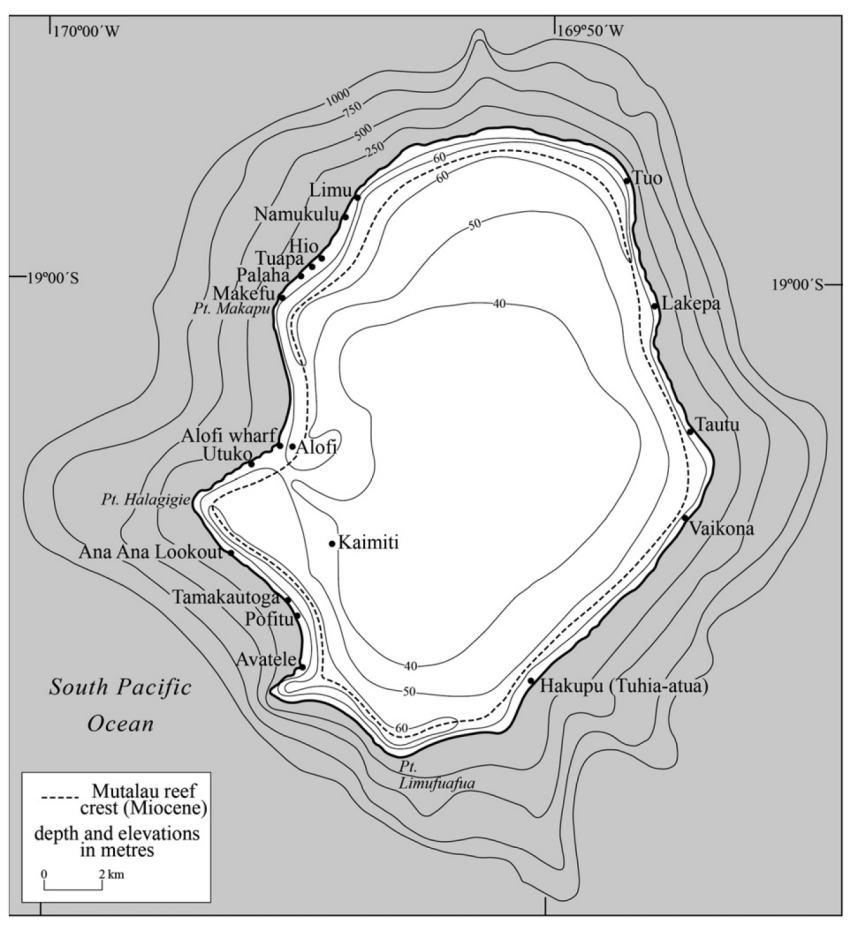

Figure 21. Bathymetric and topographic map of Niue (from Kennedy et al., 2012).

Nunn and Britton, 2004; Kennedy et al., 2012). Nunn and Britton (2004) indicated the presence of at least seven terraces, at $+58,+52,+43.5,+34,+28,+23$ and $+18 \mathrm{~m}$ with ages back to 700 ka. Kennedy et al. (2012) dated the Alofi Terrace (see Fig. 22) based on the dating of one Porites specimen at $133 \pm 0.9 \mathrm{ka}$ (WALIS U-series ID 1285; NT11; WALIS RSL ID 3981) at an elevation of $3.1 \mathrm{~m}$ above the height of living corals. This coral head consisted of more than $95 \%$ of aragonite, and the dating is considered reliable. Porites lives at median and average depths of 0 and $18.5 \mathrm{~m}$, respectively, in modern environments; however, this genus displays a wide depth range (see Table 2). Niue is affected by uplift with estimated rates of $0.13-0.16 \mathrm{~mm} / \mathrm{yr}$, with uplift considered to be ongoing (Dickinson, 2001), thus indicating an uplift of 16 to $20 \mathrm{~m}$ since $125 \mathrm{ka}$.

\subsection{Tonga}

LIG reef terraces in Tonga have been reported from outcrops at elevations of about +5 to $+7 \mathrm{~m}$. Taylor (1978) and Yonekura (1983) dated emerged reef terraces on the Tongatapu block using the alpha-counting technique. Taylor (1978) described a group of emerged notches and caves at 6.6-7.2 m above present MSL and dated a single sample at $133 \pm 12 \mathrm{ka}$ (WALIS U-series ID 1787). Yonekura (1983) described LIG reefs at $+5.5 \mathrm{~m}$ MHT and provided ages of $135 \pm 15$ and $133 \pm 12 \mathrm{ka}$ (WALIS U-series IDs 1785 and 1786; WALIS RSL ID 554). A wide palaeo-water-depth range of $0-30 \mathrm{~m}$ 
Cave

Infilled Karstic Channel

Reef Framework Unit

Modern Terrace (Shore Platform)

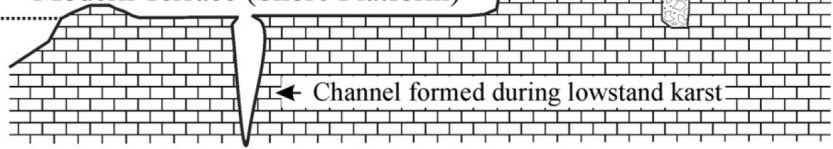

Figure 22. A schematic cross section showing the stratigraphic relationships between the Pleistocene and modern terrace on Niue. Reef framework is not ubiquitous along the Alofi Terrace edge (from Kennedy et al., 2012).

has been assumed as no taxa identification has been reported. The inaccurate dating of LIG reefs in Tonga does not allow any precise conclusion regarding the LIG RSL. Uplift rate is negligible in the Tonga arc (Yonekura, 1983).

\subsection{Fiji}

The Fiji group of islands has a total land area of $18270 \mathrm{~km}^{2}$. Its geological history is complex owing to its proximity to the Australian-Pacific plate boundary. Several Fiji Islands (e.g. Kadavu, Kaibu) exhibit a series of coral reef terraces arranged around a volcanic core, the lowest one being attributed to MIS 5e (Nunn and Omura, 1999; Nunn et al., 2002). LIG deposits from Fiji were first dated by Taylor (1978), who reported ages of $126 \pm 7$ and $136 \pm 12 \mathrm{ka}$ (WALIS U-series IDs 1866 and 1867; Yasawas1 and Yasawas2) on two unidentified corals from a terrace at +2 to $+3 \mathrm{~m}$ on Yasawa Island (WALIS RSL ID 512). However, the lack of any coral identification does not allow the precise consideration of the sea-level position at that time. Nunn and Omura (1999) have reported a similar age of $128.7 \pm 1.6 \mathrm{ka}$ from a coral sampled from the same reef terrace (WALIS U-series ID 1868; Yasawas3). In addition, Nunn and Omura (1999) reported on Kadavu Island morphological features that they have attributed to two RSL stands during the LIG without providing robust chronological constraints (see Fig. 4 in Nunn and Omura, 1999). In addition, an erosional bench reported at $+5 \mathrm{~m}$ has been interpreted as an early LIG sea-level maximum at about $136 \mathrm{ka}$, while a distinctive level at $+2 \mathrm{~m}$ would correspond to a second LIG maximum at about $120 \mathrm{ka}$. Nunn and Omura (1999) have assumed that the LIG reefs are located below present MSL in the western part of Kadavu Island.

Nunn et al. (2002) and Nunn and Omura (2003) described LIG reef terraces from Kaibu Island (see Fig. 5 in Nunn et al., 2002; Figs. 2 and 3 in Nunn and Omura, 2003) and reported three U-series ages. A Porites sampled at $1.45 \mathrm{~m}$ above the modern reef (WALIS RSL ID 511) yielded an age of $126.8 \pm 2.1 \mathrm{ka}$ (WALIS U-series ID 1865; sample AO455). Two Platygyra, including Platygyra lamellina sampled between 3.6 and $3.85 \mathrm{~m}$ above the modern reef (WALIS RSL IDs 509 and 510), gave ages of $132.8 \pm 2.3 \mathrm{ka}$ (WALIS Useries ID 1864; AO454) and 131.1 $\pm 2.4 \mathrm{ka}$ (WALIS U-series ID 1863; AO443), respectively. In modern environments, Platygyra lamellina typifies median and average depths of 4 and $4.4 \mathrm{~m}$, respectively (Table 2; WALIS RSL IDs 509 and 510). Nunn et al. (2002) interpreted the age distribution as reflecting a double sea-level maximum with peaks around 133130 and $123-120 \mathrm{ka}$, following the earlier interpretations by Nunn and Omura (1999). The earlier maximum has been reported about $2 \mathrm{~m}$ lower than the later maximum and marked by the growth of a surface reef, with the later maximum appearing to have involved only cutting of erosional shorelines at the +5.0 to $+5.5 \mathrm{~m}$ level (Nunn and Omura, 2003). Nunn et al. (2002) and Nunn and Omura (2003) compared levels of emerged shorelines on northeastern Fiji Islands and show that a LIG shoreline has emerged in northeast Fiji by around +5.0 to $+5.2 \mathrm{~m}$ (range +4.8 to $+5.5 \mathrm{~m}$ ). In addition, they compared these levels to those from the western Fiji Islands and concluded that LIG RSL in the Fijian region ranged from 4.6 to $7.1 \mathrm{~m}$ above its present mean level.

\subsection{Tuvalu}

The only available chronological information concerning the potential occurrence of LIG on Tuvalu is based on the dating of a drill core carried out on Funafuti Atoll by the Coral Reef Expedition of The Royal Society (1896-1898). It was obtained on an unidentified coral collected at $27.4 \mathrm{~m}$ (sample 274) below the reef surface and yielding a Sr isotope age of $0.14 \pm 0.15 \mathrm{Ma}$ (WALIS U-series ID 1734; Ohde et al., 2002). The carbonate sequence attributed to the LIG is reported from at least 24.4 to $27 \mathrm{~m}$ core depth and is limited by unconformities (Ohde et al., 2002).

\subsection{Kiribati}

LIG reefs have been reported from outcrops on Christmas Island and from a drill core collected on Tarawa. Marshall and Jacobson (1985) dated a drill core from an islet on Tarawa using the alpha-counting technique. The coral at a depth of 17 $17.8 \mathrm{~m}$ below MSL revealed an age of $125 \pm 9 \mathrm{ka}$ (WALIS U-series ID $1811 ; 81390010 ; 1 \sigma$ uncertainty). The sample was composed of $100 \%$ aragonite, and the dating is considered reliable.

Woodroffe and McLean (1998) dated an emerged reef terrace on Christmas Island and obtained a more accurate age using a mass spectrometer. The coral sample at an elevation of $+1 \mathrm{~m} \mathrm{MSL}$ has been dated at $130 \pm 5 \mathrm{ka}$ (WALIS U-series ID $1810 ; 16 a)$. A water depth range of $0-30 \mathrm{~m}$ has been assumed as no taxa identification has been reported. Christmas 
Island has remained stable throughout the late Quaternary (Woodroffe and McLean, 1998).

\subsection{Solomon Islands}

The geomorphology of the Solomon Islands has been studied by Stearns (1945), Grover (1958) and Stoddart (1969) describing elevated terraces in different island groups. Grover (1958) described notches on Mono Island at an elevation of $+0.76,+3$ and $+5.5 \mathrm{~m}$ on an $8.5 \mathrm{~m}$ high cliff and at $+22 \mathrm{~m}$ on a 16.8 to $29.6 \mathrm{~m}$ high cliff. Stoddart (1969) mentioned the occurrence of Pleistocene reef limestones and reported terraces of clastic debris with reef material at elevations of 145 to $135,80,60,44$ and $27.5 \mathrm{~m}$ above present MSL. He also reported tidal notches on Banika island with an elevation of 1.5 to $5 \mathrm{~m}$ above present MSL. A terrace on Banika island at $9 \mathrm{~m}$ above present MSL was older than 39700 years. However, it was impossible to relate the relevant benches to specific Pleistocene RSL changes. The Solomon Islands are affected by uplift. There are 16 arc segments in the Solomon Islands comprising three major tectonic regimes (Chen et al., 2011).

\subsection{Vanuatu}

Uplifted Quaternary reef terraces cover wide areas of Vanuatu islands, specifically Santo, Malakula and Efate at elevations ranging from $600 \mathrm{~m}$ on Efate and the north of Malakula, to $860 \mathrm{~m}$ in the south of Malakula and up to more than $1000 \mathrm{~m}$ in the western part of Santo (see Fig. IV-2 in Jouannic et al., 1982). They form the external part of a succession of terraces overhanging a Holocene coastal reef platform. Since the first geological and morphological investigations in the late 1960s and the 1970s (Mitchell, 1966, 1969, 1971; Robinson, 1969; Mallick and Greenbaum, 1977; Ash et al., 1978), these uplifted terraces have been the topic of studies dealing with both their chronology and the reconstruction of vertical movements in the New Hebrides forearc.

The first chronological study was carried out by Neef and Veeh (1977), who published the first four U-series ages obtained on corals from MIS 5 raised reefs from Efate and Malo, which occur at +100 and $+96 \mathrm{~m}$, respectively. These raised reefs have been interpreted as coeval to RSL stands VIIa (140 000 years) and VIIb (120000 years) from Huon Peninsula (Chappell, 1974; Bloom et al., 1974), respectively. The two ages obtained by Neef and Veeh (1977) were of $134 \pm 10 \mathrm{ka}$ (WALIS U-series ID 1847; Efate 330) and $134 \pm 6 \mathrm{ka}$ (WALIS U-series ID; Ma 1) and were judged to be more reliable than those which yielded ages of about $120 \mathrm{ka}$ (Efate X and Efate 235) on the basis of mineralogical criteria used in the evaluation of samples (Neef and Veeh, 1977). However, corals that have been dated were not identified, thus hampering the accurate reconstruction of palaeo-water-depth during reef growth. Subsequent studies by Bloom et al. (1978), Jouannic et al. (1980, 1982), and Lecolle and Bernat (1985) have been focused on the up- lifted terraces from Efate. Two alpha spectrometry ages of $141 \pm 8 \mathrm{ka}$ (WALIS U-series IDs 1952 and 1953; E-L-3 and E-T-2) were obtained by Bloom et al. (1978) on unidentified corals from the coral terrace located at +110 to $+130 \mathrm{~m}$ in the Port Havannah area (WALIS RSL IDs 491 and 492). Additional U-Th ages of $124 \pm 7 \mathrm{ka}$ (WALIS U-series ID 1950; sample I-7-5), $131 \pm 11$ ka (WALIS U-series ID 1951; E-L-1), 121.6 $\pm 7.3 \mathrm{ka}$ (WALIS U-series ID 1942; EKB42) and $125.3 \pm 7.5 \mathrm{ka}$ (WALIS U-series ID 1941; EKB4) were obtained by Jouannic et al. (1982) and Lecolle and Bernat (1985) on the same terrace (WALIS RSL IDs 491 and 492). This terrace has therefore been attributed to MIS $5 \mathrm{e}$, and its duplication in the area of Port Havannah, similar to the one observed by Bloom et al. (1974) on Huon Peninsula (VIIa and VIIb terraces; Bloom et al., 1974), has been interpreted as resulting from low-amplitude sealevel fluctuations during MIS 5e (Jouannic et al., 1982). Two ages of $130 \pm 7 \mathrm{ka}$ (WALIS U-series ID 1948; sample E-X-2) and $114 \pm 6 \mathrm{ka}$ (WALIS U-series ID 1949; sample E-X-4) have been obtained on the coral reef terrace at +85 to $+95 \mathrm{~m}$ in the same area (Jouannic et al., 1982). The MIS 5e terrace has been dated by Lecolle and Bernat (1985) at different altitudes in several other areas on Efate Island (see Fig. 2 in Lecolle and Bernat, 1985). An age of $121.4 \pm 7.3 \mathrm{ka}$ (WALIS U-series ID 1937; sample ESA3) was reported at $+50 \mathrm{~m}$ in the Siviri area (WALIS RSL IDs 706 through 708), while ages of $128.0 \pm 7.7 \mathrm{ka}$ (WALIS Useries ID 1938; ERB1) and $133.5 \pm 8 \mathrm{ka}$ (WALIS U-series ID 1939; sample EWA03) were obtained on the terrace occurring at $+80 \mathrm{~m}$ in the Malafao area (WALIS RSL ID 709). Ages of $117.8 \pm 7.0 \mathrm{ka}$ (WALIS U-series ID 1945; ETD1) and $123.6 \pm 7.4 \mathrm{ka}$ (WALIS U-series ID 1946; ETA4) on the terraces at +80 and $+100 \mathrm{~m}$, respectively, in Tukutuk area were found (WALIS RSL ID 713). However, the palaeo-MSL cannot be further constrained due to the lack of coral identification. Chronological data obtained on Efate Island, combined with U-series ages obtained on Malakula and Santo islands, have been used to reconstruct vertical tectonic movements in the New Hebrides Island arc (Jouannic et al., 1982; Lecolle and Bernat, 1985). The chronological frame of the MIS 5e terrace from Efate has been reassessed by Edwards et al. (1987a, b), who identified and dated the two corals previously reported by Bloom et al. (1978) at $129.9 \pm 1.1$ and $129.2 \pm 1.1 \mathrm{ka}$ for Oulophyllia crispa (WALIS U-series IDs 1435 and 1436; E-T-2-A and E-T-2) and $125.5 \pm 1.3 \mathrm{ka}$ for Porites lutea (WALIS U-series ID 1854; E-L-3). The association of those two coral species indicates probable palaeowater-depths of less than $10 \mathrm{~m}$ (WALIS RSL ID 492).

The reef terrace corresponding to MIS 5e (from 119 to $132 \mathrm{ka}$ ) was not clearly identified on Malakula Island (Jouannic et al., 1982; Cabioch and Ayliffe, 2001; see Fig. 4 in Taylor et al., 1980). Jouannic et al. (1982) also suggested that some of the discrepancies in terrace altitudes in previous work may have been due to problems associated with coral reworking and errors in altitude assignment. An age 
of $119.8 \pm 8.0 \mathrm{ka}$ (WALIS U-series ID 1947; NH14) has been obtained on the coral reef terrace located at $+180 \mathrm{~m}$ in the Npénanavet-Tenmaru area by Jouannic et al. (1982). A similar age of $121.3 \pm 1.2 \mathrm{ka}$ (WALIS U-series ID 1846; Espiegle1-188m) has been obtained at $+188 \mathrm{~m}$ by Cabioch and Ayliffe (2001) on an unidentified coral (WALIS RSL ID 490; see Fig. 23). However, Cabioch and Ayliffe (2001) have considered that the MIS 5e terrace should correspond to the wide plateau culminating at $+230 \mathrm{~m}$ and that, based on field evidence, its composite reef structure may result from minor sea-level variations during the MIS 5e RSL stand.

Taylor et al. (1985) have investigated raised coral reef terraces from the Torres Islands to reconstruct rapid vertical movements in the New Hebrides forearc. They interpreted the very wide terrace at about $+100 \mathrm{~m}$ on Toga (WALIS RSL ID 488; see Fig. 24) as being formed during the MIS $5 \mathrm{e}$ and deduced uplift rates of about $1 \mathrm{~mm} / \mathrm{yr}$ for at least the past 125000 years, i.e. $125 \mathrm{~m}$ since $125 \mathrm{ka}$. Ages assigned to MIS 5e have been reported from the reef terrace located at $+80 \mathrm{~m}$ on Loh Island (WALIS RSL ID 487; see Fig. 25) where a Porites and a Leptoria phrygia yielded ages of $122 \pm 7 \mathrm{ka}$ (WALIS U-series ID 1839; LO-B-2) and $135 \pm 11 \mathrm{ka}$ (WALIS U-series ID 1840; LO-B-3), respectively. In modern reefs, Leptoria phrygia typifies shallowwater environments with median and average depths of 4 and $5 \mathrm{~m}$, respectively; however, this species displays a rather large depth range, from the surface down to $30 \mathrm{~m}$ or even $47 \mathrm{~m}$ (Table 2).

On Tanna Island, raised lagoonal deposits currently at +18 m (WALIS RSL ID 506; see Fig. 26) have been attributed to MIS 5e based on an age of $126.7 \pm 1.5 \mathrm{ka}$ (WALIS U-series ID 1861; Ta9) obtained on an Acropora, which does not give precise indications on the palaeo-water-depth during reef growth.

\subsection{New Caledonia}

New Caledonia comprises the main island (Grande Terre), the Isle of Pines to the south, the Loyalty Islands to the east (Maré, Lifou, Tiga and Ouvéa) and the Belep Archipelago to the northwest.

LIG reef deposits have been reported both from outcrops in Loyalty Islands (Maré, Lifou and Ouvéa) and from drill cores that have been carried out throughout the modern barrier and fringing reefs from the western coast of Grande Terre, as well as in the Chesterfield islands that are located about $500 \mathrm{~km}$ to the WNW of New Caledonia.

Pioneering studies on Pleistocene reef terraces from the Loyalty Islands, including the LIG, have been carried out in the 1970s by Launay and Récy (1972) and Coudray (1976). The first radiometric ages on these raised reefs have been obtained by Bernat et al. (1976), Marshall and Launay (1978), and Gaven and Bourrouilh-Le Jan (1981) and were used to reconstruct tectonic movements of these islands since Quaternary times.
${ }^{230} \mathrm{Th}-{ }^{238} \mathrm{U}$ ages reported by Bernat et al. (1976) on raised reefs occurring at +11 to +12 m elevation on Lifou and Maré range from 122 to $120 \mathrm{ka}$ and would therefore indicate that this terrace corresponds to MIS 5e. A coral from an elevation of $+20 \mathrm{~m}$ on the Isle of Pines, which is located immediately to the southeast of New Caledonia, was dated at $126 \pm 5 \mathrm{ka}$. However, this suite of corals did not satisfy the closed-system criteria because they were partly recrystallized (Marshall and Launay, 1978). Marshall and Launay (1978) could not obtain reliable ages on a terrace located at $+3.5 \mathrm{~m}$ on Lifou, but they have reported an age of $117 \pm 6 \mathrm{ka}$ on a Platygyra colony (WALIS U-series ID 1791; Ouvea3) sampled in the coral reef terrace occurring at $+7.5 \mathrm{~m}$ on Ouvéa (WALIS RSL ID 737) and correlated this terrace with the $120 \mathrm{ka}$ Waimanalo shoreline from Hawaii (Ku et al., 1974). The distribution of modern Platygyra is characterized by median and average depths of 4 and $7 \mathrm{~m}$, respectively; however, their depth range is very large and extends from the surface down to $80 \mathrm{~m}$ (Table 2). Marshall and Launay (1978) have concluded that there is evidence of LIG reef terraces at +11 to $+12 \mathrm{~m}$ on Lifou, at $+20 \pm 3 \mathrm{~m}$ on the Isle of Pines (Bernat et al., 1976), and at $+7.5 \mathrm{~m}$ on Ouvéa, but, because of diagenetic alteration of the Lifou and Isle of Pines coral samples, the exact age of these terraces could not be defined. Gaven and BourrouilhLe Jan (1981) have reported ages ranging from 100 to $295 \mathrm{ka}$ on pristine corals sampled in terraces located between 0 and $+9 \mathrm{~m}$ on Maré. They have noted that some of these terraces have been karstified and attributed notches at +9 and $+12 \mathrm{~m}$ to 125 and $205 \mathrm{ka}$ RSL.

The study of drill cores from modern reefs from several areas of the west coast of New Caledonia (Amédée, Kendec and Ténia islets) has provided the opportunity to document reef units attributed to MIS 5e that occur at various depths, thus demonstrating differential tectonic movements along the west coast of New Caledonia (see Fig. 1 in Cabioch et al., 2008).

Below fringing and barrier reefs, the $125 \mathrm{ka}$ reef unit is generally capped by calcretes resulting from a relatively long period of emergence and is locally affected by freshwater alteration, even if the barrier reef is frequently unaltered. Several alpha-counting U-Th dates have been obtained on these drill cores: $125 \pm 20 \mathrm{ka}$ in the Ténia drill cores (Coudray, 1976 ), $135 \pm 12.8 \mathrm{ka}$ in the Îlot Vert drill cores (DegaugueMichalski, 1993) and $125 \pm 1$ and $131 \pm 1 \mathrm{ka}$ at Îlot Amédée (in cores Amédée-1 and Amédée-2, respectively; Cabioch et al., 1996), where a framework of corals and coralline algae with a few bioclastic beds typifies reef flat facies. In the Amédée- 4 drill core, the $125 \mathrm{ka}$ reef occurs between 14 and $37 \mathrm{~m}$ core depth (WALIS RSL ID 474) and is predominantly composed of biocalcarenites and rare coral colonies (Cabioch et al., 1999). U-Th dating by high-precision ionization mass spectrometry (TIMS) carried out on coral samples extracted from the Amédée site has demonstrated that the distribution of $\mathrm{U}$ and $\mathrm{Th}$ isotopes was affected by subaerial diagenesis during emergence of the reef units, while 


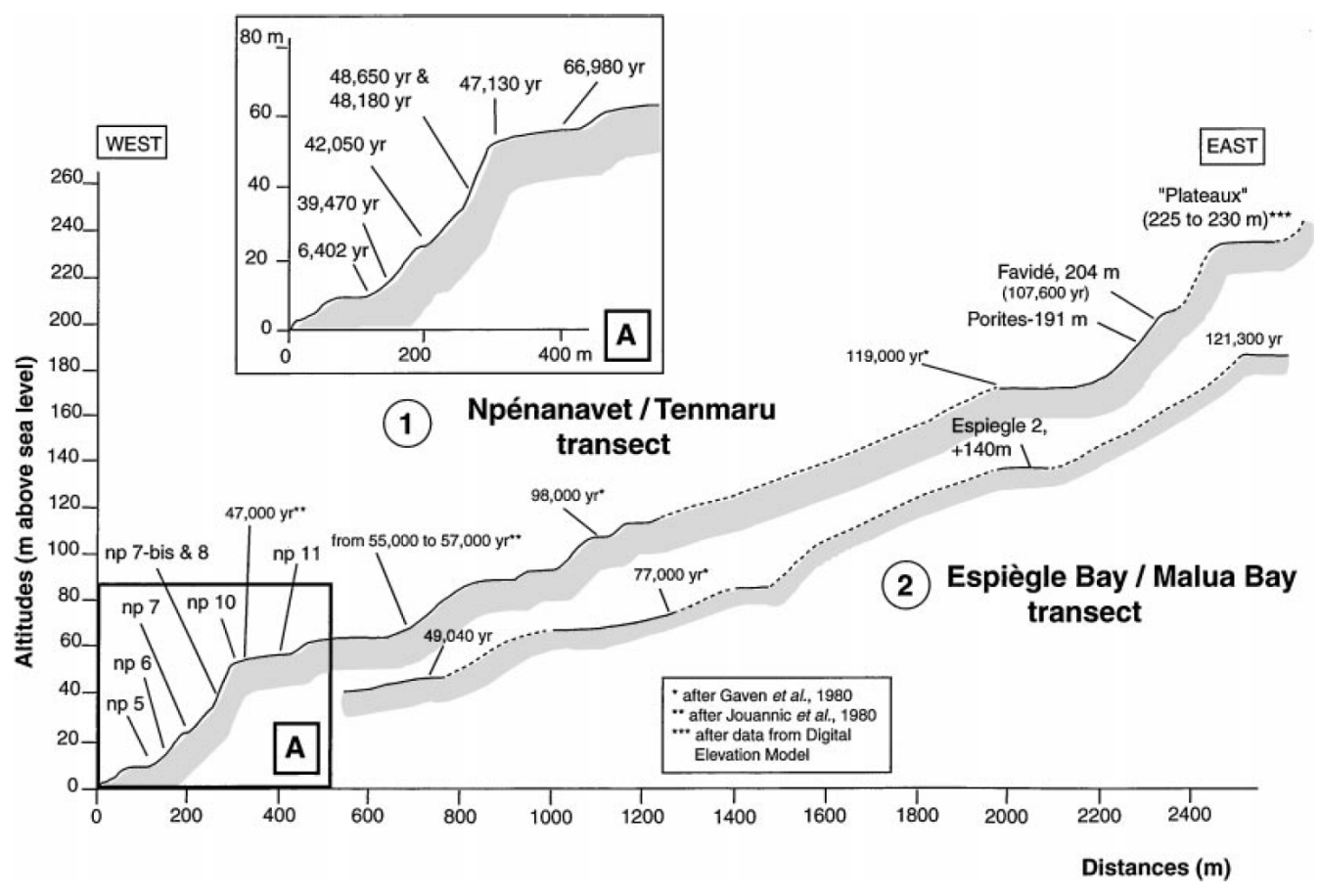

Figure 23. Profile showing the distribution of reef terraces on Malakula. Transect 1: Npénanavet-Tenmaru transect; transect 2: Espiègle Bay-Malua Bay transect (from Cabioch and Ayliffe, 2001).

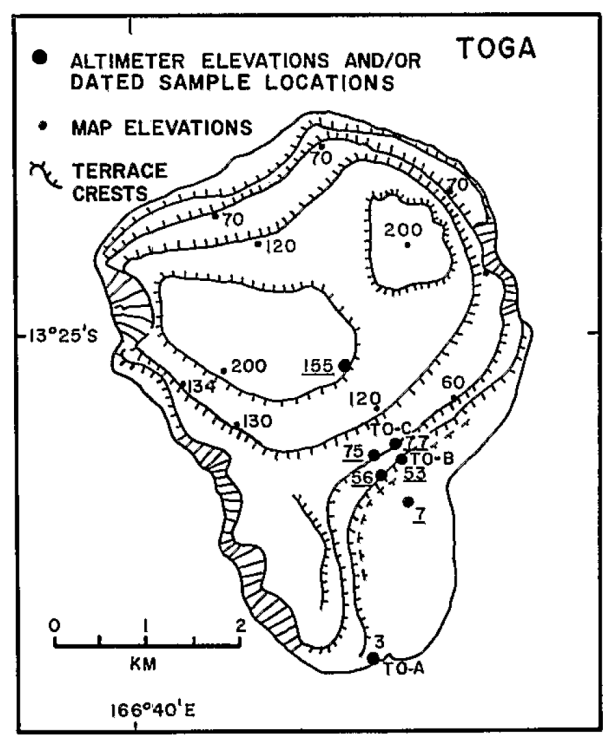

Figure 24. Raised reef terraces on Toga Island (from Taylor et al., 1985).

the Holocene coral sequence seems largely unaffected (Frank et al., 2006; Cabioch et al., 2008). Various correction models were tested to get reliable ages from the late Pleistocene sequences and yielded ages ranging from 102.6 \pm 4.4 to $127.5 \pm 5.4 \mathrm{ka}$, with a majority of values around $122 \mathrm{ka}$ (Frank et al. 2006; Cabioch et al., 2008). The reef unit oc-

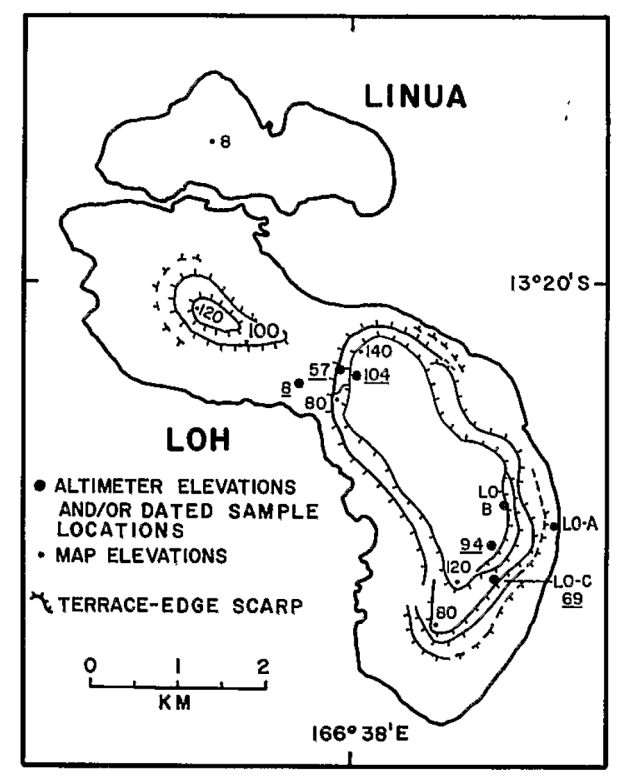

Figure 25. Raised reef terraces on Loh and Linua (from Taylor et al., 1985).

curring between 37 and $14 \mathrm{~m}$ core depth has therefore been attributed to MIS 5, especially to MIS 5e (WALIS U-series IDs 1266 through 1283; WALIS RSL ID 474; see Fig. 27); based on these results, the local subsidence rate has been estimated to $0.16 \mathrm{~mm} / \mathrm{yr}$ (Frank et al., 2006), thus a total of $20 \mathrm{~m}$ since $125 \mathrm{ka}$. 


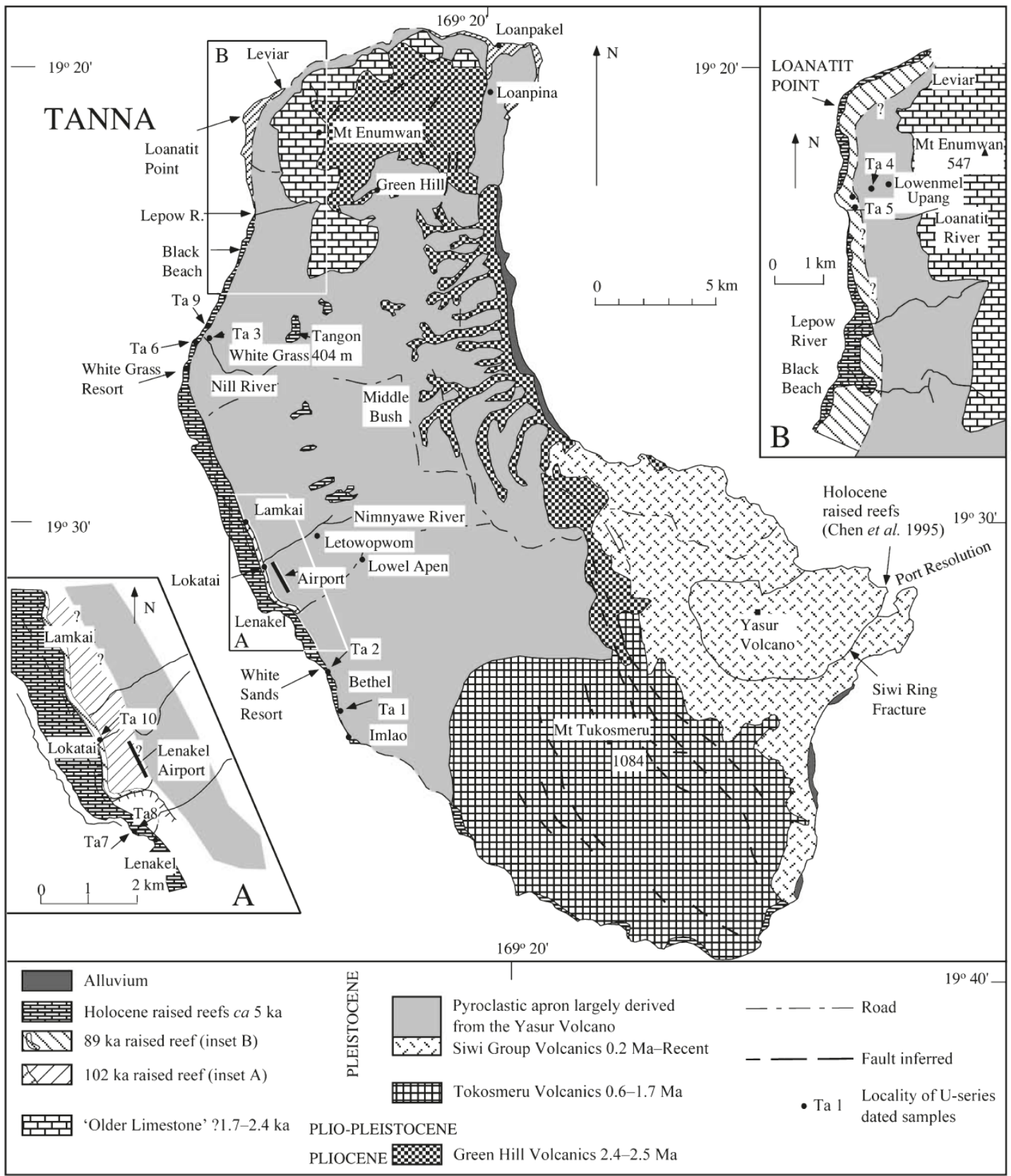

Figure 26. Raised reef terraces on Tanna Island (from Neef and Hendy, 1988, and Neef et al., 2003).

Similar Pleistocene reef units have been identified in drill cores retrieved from the Kendec (Cabioch et al., 2008) and Vert (Cabioch, 1988; Degaugue-Michalski, 1993) islets. Coral identifications (Hongo and Wirrmann, 2015) have shown that the MIS 5 reef units are dominated by important accumulations of shallow-water assemblages including arborescent colonies of Acropora (Kendec drill core), corymbose and tabular colonies of Acropora (Kendec and Amédée4 drill cores) and massive Porites colonies (Amédée-5 drill core) that characterize reef edge and upper reef slope environments exposed to strong wave action.
Below the barrier reef that occurs at Ténia islet, the $125 \mathrm{ka}$ unit consists of a framework of corals, bryozoans and coralline algae trapped in bioclastic sediments rich in bryozoans, typifying reef flat facies (Coudray, 1976). The reef unit occurring between 14 and $16 \mathrm{~m}$ core depth in drill cores extracted more recently in this area (Ténia-3; Montaggioni et al., 2011) has yielded U-series ages of $127.9 \pm 3.3 \mathrm{ka}$ (WALIS U-series ID 1788; 14T3), $130.55 \pm 3.75 \mathrm{ka}$ (WALIS U-series ID $1789 ; 16 \mathrm{~T} 3$ ) and $132.65 \pm 4.7 \mathrm{ka}$ (WALIS Useries ID 1790; 18T3), according to the U-Th dating procedure previously described by Frank et al. (2006). 


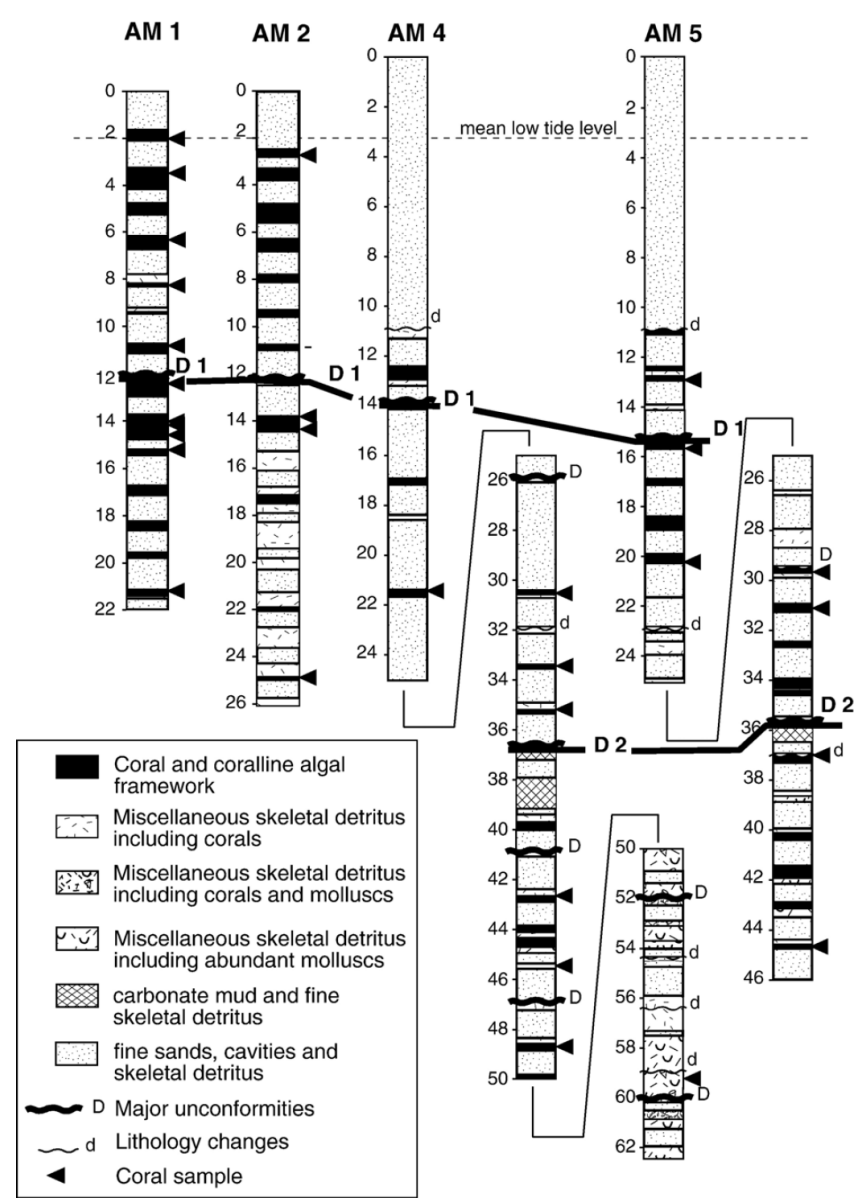

Figure 27. Synthetic log of the four cores drilled at Amédée Islet. D1 is the Pleistocene-Holocene boundary unconformity; D2 is the bottom of the LIG terrace (from Frank et al., 2006).

\subsection{Papua New Guinea}

Quaternary coral reef terraces from Huon Peninsula (Papua New Guinea) are prominent morphological features that extend more than $80 \mathrm{~km}$ along the coast and have been uplifted at a rate that varies from $0.5 \mathrm{~mm} / \mathrm{yr}$ in the northwest to nearly $4 \mathrm{~mm} / \mathrm{yr}$ to the southeast (Esat et al., 1999). They range in elevations from 0 to $200 \mathrm{~m}$ (see Figs. 28 and 29) and consist of an upward succession of fringing and barrier reef types. Seven coral reef terraces, I through VII from the coast landwards, are spaced at about $20 \mathrm{kyr}$ intervals (see Figs. 28 and 29) and provide a rather complete record of RSL, oxygen isotopes and temperature of the surface tropical ocean over the duration of the high-RSL events of the last glacial cycle (Aharon and Chappell, 1986). These uplifted coral reef terraces have been recognized and extensively studied since the pioneer works of Veeh and Chappell (1970). Huon Peninsula now represents a classical site of RSL change studies in support of the astronomical theory of climate change (Chappell, 1973).
Reef tract VII is a large structure with a barrier reef, a lagoon and an inner fringing reef occurring at the crest of the relief (see Figs. 30 and 31). The main body of reef tract VII overlies the upper Tertiary limestone of the north Huon Peninsula (the Cromwell Limestone). Terraces VIb, VIa (above VIb) and V (below VIb) are platforms of younger raised fringing reefs that offlap the front of reef tract VII (see Figs. 28 to 31). Uplift rates for the Huon Peninsula have been estimated from terrace VIIb, which has been dated at 118 to $120 \mathrm{ka}$ with an assumed palaeo-RSL at 0 to $+5 \mathrm{~m}$ (Chappell, 1974; Bloom et al., 1974; Aharon and Chappell, 1986; Chappell and Polach, 1991; Chappell and Shackleton, 1986).

The first radiometric ages concerning Huon Peninsula reef terraces were obtained by Veeh and Chappell (1970) on coral colonies and molluscs (Tridacna gigas). Three U-series ages (alpha spectrometry), which could be assigned to MIS 5, were obtained on unidentified corals from what they called the "Reef Complex V", reported as "Reef Complex VII" by Bloom et al. (1974) and interpreted as being built during the 125-120 ka time window.

The oldest ages of $140 \pm 10$ and $133 \pm 10 \mathrm{ka}$ were obtained on a sample collected from fringing-reef terrace VIIa, on the landward side of the lagoon floor of reef complex VII on the Sialum profile. The youngest ages reported by Veeh and Chappell (1970) were of $116 \pm 7$ and $119 \pm 7 \mathrm{ka}$ and concerned a sample collected from near the crest of the barrier reef at Sialum (near the Kwambu profile) referred to as VIIb crest by Bloom et al. (1974). The large errors in all these analyses did not allow a definite conclusion about the precise chronology of Terrace VII.

Bloom et al. (1974) reported a single datable coral sample from the undercut base of a large cliff at the front of the barrier of reef complex VII, about $20 \mathrm{~m}$ below the ridge crest, on the Nama traverse. The reported age is of $142 \pm 8 \mathrm{ka}$ and concerns a Porites lutea colony, which most commonly occurs at water depths of less than $10 \mathrm{~m}$, with median and average depths of 0 and $2.7 \mathrm{~m}$, respectively, in modern environments (Table 2). However, Bloom et al. (1974) had insufficient samples to document the age of terrace VII and selected an arbitrary age of $125 \mathrm{ka}$ for this terrace. Based on the chronology provided by Bloom et al. (1974), Chappell (1974) has made a parallel between the described raised coral terraces and coastal terraces from other parts of the world, especially Barbados where transgression maxima were previously established around 6.4, 29, 35, 60, 74, 118, 137, 185, 218 and $>250000 \mathrm{ka}$.

The combined use of previous chronology and oxygen isotope records from Tridacna gigas occurring in uplifted reef terraces allowed Aharon (1983) and Aharon and Chappell (1986) to quantitatively evaluate ice volume and temperature factors. They established that sea level rose rapidly by 5 to $6.5 \mathrm{~m}$ above present MSL during the LIG, which on stratigraphic grounds and $\delta^{18} \mathrm{O}$ compositions can be separated into an early phase whose $\delta^{18} \mathrm{O}$ is similar to modern values (reef 


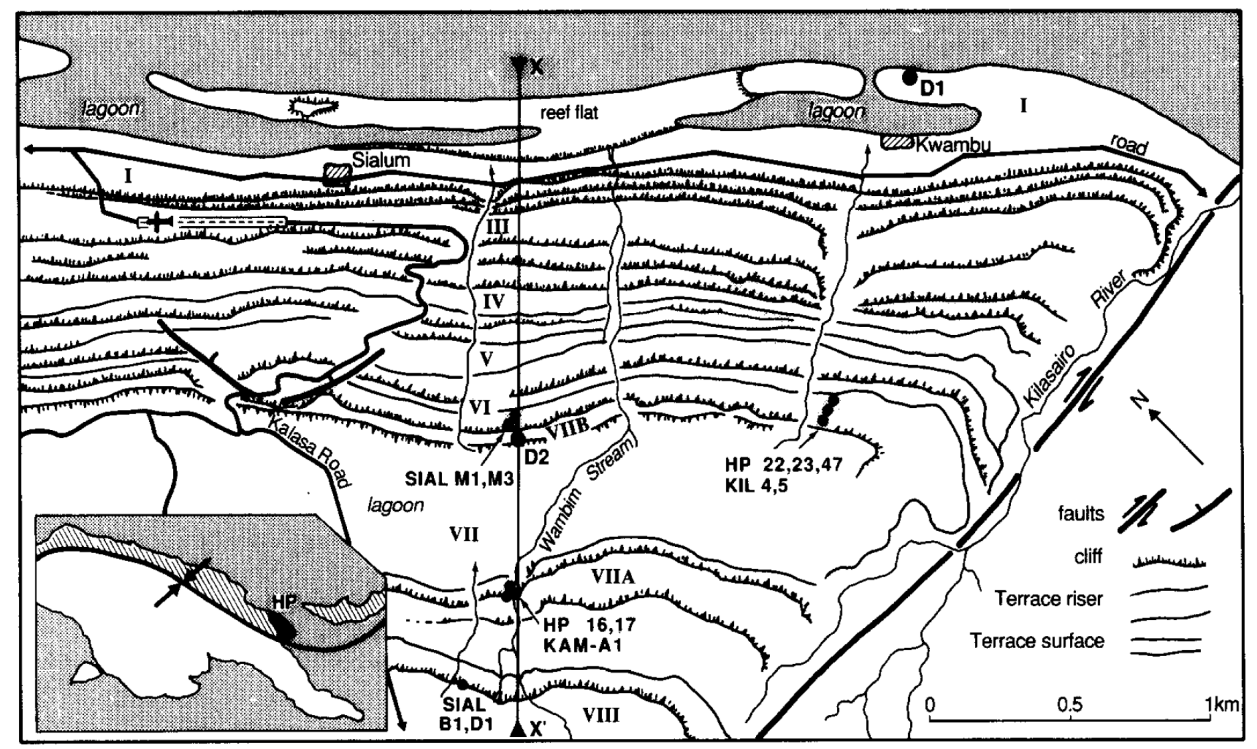

Figure 28. Location and generalized physiography of the emerged reef terraces on Huon Peninsula (from Stein et al., 1993). Spot elevations in metres. Reef numbering (I to VIII) follows Chappell (1974). Inset map shows position of study area in Papua New Guinea.

VIIa dated at $138 \mathrm{ka}$ ) and a late phase that is $0.6 \%$ o heavier (reef VIIb dated at $118 \mathrm{ka}$ ).

A comprehensive chronological study of the LIG coral reef terraces from Huon Peninsula has been carried out by Stein et al. (1993). Valid U-series ages reported from the Kwambu section (Sialum area) at elevations ranging from +197 to $+229 \mathrm{~m}$ fall into two tight groups centred at 118 and $134 \mathrm{ka}$ (WALIS RSL IDs 464 through 470) and replicate with considerably more precision the few previous alpha-counting results. This confirms the chronological frame of reef complex VII (see Fig. 30), with ages around 118 ka to the VIIb barrier and 130-140 ka to the VIIa fringing reef, respectively (Chappell, 1974).

The group centred at $118 \mathrm{ka}$ includes ages ranging from $116.4 \pm 1.8 \mathrm{ka}$ (WALIS U-series ID 1325 ; KIL-5b) to $119.5 \pm 1.2 \mathrm{ka}$ (WALIS U-series ID 1327; KIL-5a-1) and concerns colonies of Porites lutea that likely indicate a depositional environment shallower than $10 \mathrm{~m}$, and colonies of Platygyra lamellina and Gardineroseris planulata, which also likely indicate a reef setting shallower than $10 \mathrm{~m}$ (WALIS RSL IDs 466 through 469). The group centred at $134 \mathrm{ka}$ includes ages ranging from $131.9 \pm 1.2 \mathrm{ka}$ (WALIS U-series ID 1322; HP-23b) to $136.7 \pm 1.2$ (WALIS U-series ID 1313) ka and mostly concerns colonies of Gardineroseris planulata and Gardineroseris sp., as well as Cyphastrea serailia typifying superficial environments shallower than $6 \mathrm{~m}$ (see Table 2; WALIS RSL IDs 464, 465 and 470). These results show that the barrier VIIb includes corals of the two age groups and that corals of $118 \mathrm{ka}$ appear in the outer margin of VIIa, $3 \mathrm{~m}$ below the crest of VIIb and on the seaward surface of the barrier ( $30 \mathrm{~m}$ below the crest). This configuration suggests that the younger corals $(118 \mathrm{ka})$ were uncon- formably deposited on the relief of the VIIb barrier. The main structure of the coral reef terrace VII is therefore believed to have developed during a major and continuous sea-level rise that commenced well before $134 \mathrm{ka}$ and continued until $118 \mathrm{ka}$ (Stein et al., 1993). Results obtained by Stein et al. (1993) have been reassessed by Esat et al. (1999), who noted that these two age clusters are separated vertically by $7 \mathrm{~m}$, thus indicating that the RSL at $136 \mathrm{ka}$ could have been $43 \mathrm{~m}$ lower than at $118 \mathrm{ka}$, given the $1.9 \mathrm{~mm} / \mathrm{yr}$ uplift rate (Stein et al., 1993).

Esat et al. (1999) have investigated a large ancient sea cave, Aladdin's Cave, at the base of terrace VIb (MIS 5b$5 c$ ) in the Kwangam section (see Fig. 31). Most of the acceptable ages of corals from Aladdin's Cave are within the range of 126 to $134 \mathrm{ka}$ (WALIS U-series IDs 1296 through 1299 and WALIS U-series IDs 1302 through 1312), with the exception of a coral sample dated at $115 \pm 0.9 \mathrm{ka}$ (WALIS U-series ID 1301; AC-U12). The corals exposed within Aladdin's Cave include abundant and large heads of Porites (up to $1 \mathrm{~m}$ in diameter) and various Faviidae (now called Merulinidae; Huang et al., 2014), indicating water depth shallower than $20 \mathrm{~m}$ during their growth (WALIS RSL IDs 459, 462 and 463). Ages obtained independently by TIMS and alpha spectrometry on a large Porites colony at the cave entrance are in excellent agreement (WALIS U-series IDs 1307 through 1309; AC-U11a-top, AC-U11a-bottom, ACU11-bottom) and average $127.6 \pm 0.6 \mathrm{ka}$. The mean age of corals from the crest of reef VII is $134 \pm 1 \mathrm{ka}$, and the mean age of the Aladdin's Cave corals of this time interval is $130 \pm 2 \mathrm{ka}$. The corals at the cave appear to have grown $\sim 4000$ years later than those that are found $10 \mathrm{~m}$ below VIIb or $\sim 80 \mathrm{~m}$ above the cave and appear to have grown in con- 


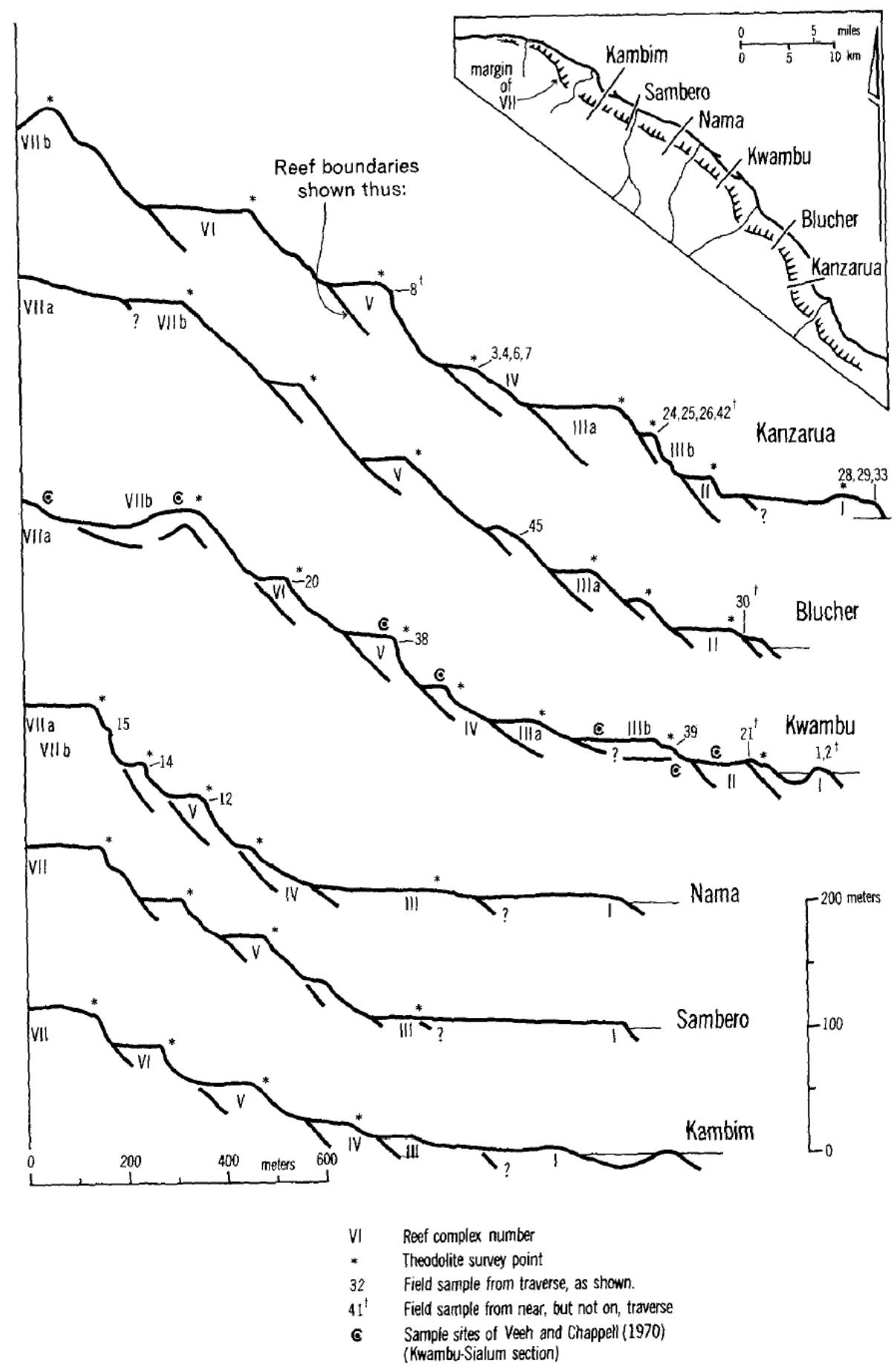

Figure 29. Emerged reef terraces on Huon Peninsula. Reef complexes I to VII are shown by Roman numerals. Sample numbers are shown as close as possible to their collection localities (from Bloom et al., 1974).

ditions $6{ }^{\circ} \mathrm{C}$ cooler than present. The conflict between samples from Aladdin's Cave (about $+100 \mathrm{~m}$ at about $130 \mathrm{ka}$ ) and from the coral reef terrace VII (up to $+220 \mathrm{~m}$ at about $134 \mathrm{ka}$ ) has been explained by a sea-level drop of 60 to $80 \mathrm{~m}$ after the development of the reef terrace VIIb (Esat et al., 1999; see Fig. 32). A new rise in sea level after $130 \mathrm{ka}$ is de- duced from the dataset and occurred in response to the major insolation maximum at 126 to $128 \mathrm{ka}$ (Esat et al., 1999). The $118 \mathrm{ka}$ corals of reefs VIIa and VIIb may have also been deposited during an episode of sea-level rise at the end of the LIG (Esat et al., 1999). 

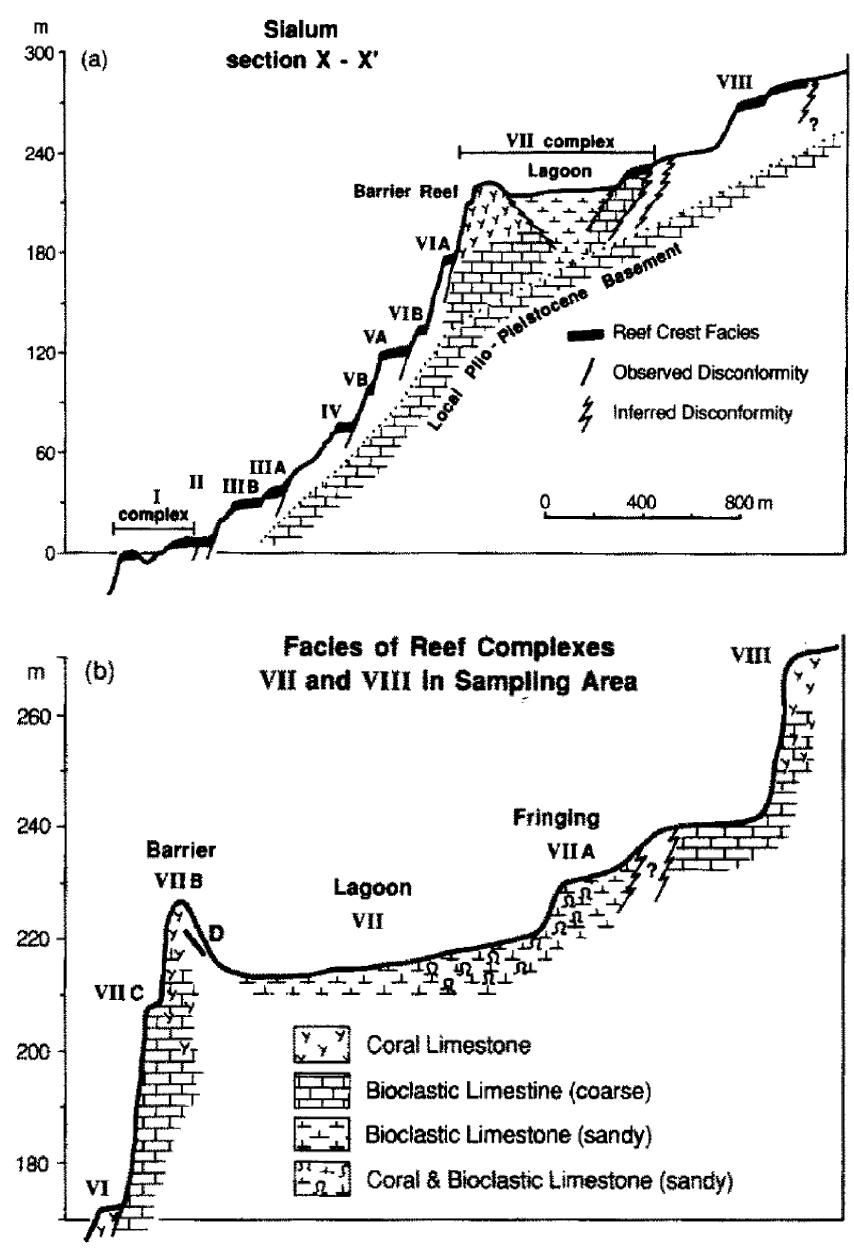

Figure 30. (a) Vertical profiles of terraces I to VIII on transect $x-x^{\prime}$. (b) Enlargement of reef complex VII on transect $x-x^{\prime}$ (from Stein et al., 1993).

Cutler et al. (2003) have dated coral samples from reef terraces VI (Sialum area) and VIIb (Kilasairo area) by applying both ${ }^{230} \mathrm{Th}$ and ${ }^{231} \mathrm{~Pa}$ dating techniques as a test of age accuracy. The two Porites samples from the coral reef terrace VI occurring at elevations of +169 to $+177 \mathrm{~m}$ gave ages of $119.34 \pm 0.76 \mathrm{ka}$ and $121.87 \pm 0.78 \mathrm{ka}$ (WALIS Useries ID 1290 and 1291, respectively). The identified corals indicate a rather large palaeo-water-depth range, from 0 to $20 \mathrm{~m}$ (WALIS RSL IDs 457 and 458). Four samples of Gardineroseris planulata from coral reef terrace VIIb at $+195 \mathrm{~m}$ yielded ages ranging from $117.77 \pm 0.69$ to $113.9 \pm 0.65 \mathrm{ka}$ (WALIS U-series ID 1289 and 1742, respectively; KIL3a and KIL3b). This result apparently confirms the U-series age of $116.6 \pm 1.15 \mathrm{ka}$ previously obtained by Stein et al. (1993; WALIS U-series ID 1292), but discordant $\mathrm{Pa}-\mathrm{Th}$ or Th$\mathrm{U}$ series ages are reported (Cutler et al., 2003). The reported corals indicate a shallow-water depositional environment, shallower than $10 \mathrm{~m}$ (WALIS RSL IDs 455 and 456), with median and average depths of 3 and $5.9 \mathrm{~m}$, respec-

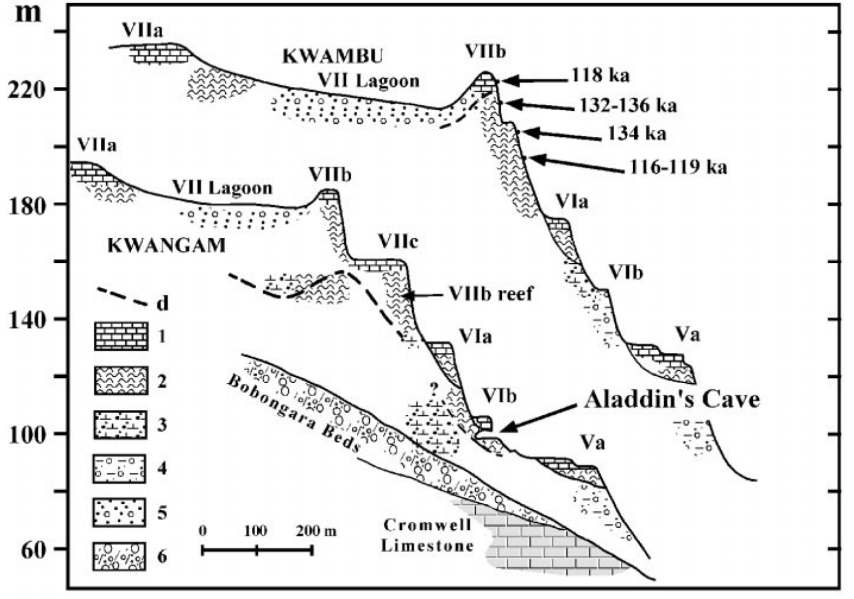

Figure 31. A profile of coral terraces V to VII, including Aladdin's Cave at the base of reef VIb 870 at west Kwangam and the equivalent reefs at Kwambu. The horizontal scale for both sections is $1: 15000$, which was calculated from air photographs; the vertical scale for Kwambu was calculated from a theodolite survey, and the vertical scale for Kwangam was calculated from a calibrated digital altimeter (from Esat et al., 1999).

tively, in modern environments. Based on their database, Cutler et al. (2003) concluded that MIS 5e ended prior to $113.1 \pm 0.7 \mathrm{ka}$, when RSL was at $-19 \mathrm{~m}$. In addition, uplift rates of $1.85 \mathrm{~mm} / \mathrm{yr}$ for Sialum, Kwambu, and Kilasairo; $2.6 \mathrm{~mm} / \mathrm{yr}$ for Kanomi; and $2.8 \mathrm{~mm} / \mathrm{yr}$ for Kanzarua were calculated based on the dating results obtained on Terrace VIIb (Cutler et al., 2003).

Recently, Ayling et al. (2017) investigated the chemical and isotopic distribution of uranium in Tridacna gigas from Marine Isotope Stage (MIS) 5e (128-116 ka) and MIS 11 (424-374 ka) reefs and demonstrated that they cannot provide independent, reliable geochronological controls on the timing of past reef growth at Huon Peninsula.

\subsection{Federated States of Micronesia}

Pleistocene limestones, including the LIG period, have been described in this region; however, no dates have been reported in the reviewed studies. The hydrogeologic study on Pingelap and Pohnpei by Ayers and Vacher (1986) indicated that the Pleistocene aquifer is located at a depth of $20-30 \mathrm{~m}$. Anthony (1996a, b, c) and Anthony and Spengler (1996) provided several hydrogeologic reports on islands in Pohnpei and indicated the presence of Pleistocene deposits with a Holocene-Pleistocene contact at depths of 15-25 m below present MSL. Fletcher and Richmond (2010) summarized in a report that the Pleistocene limestone beneath the islands in this region at depths from about 8 to $28 \mathrm{~m}$ below the modern reef platform was deposited during the LIG period. 


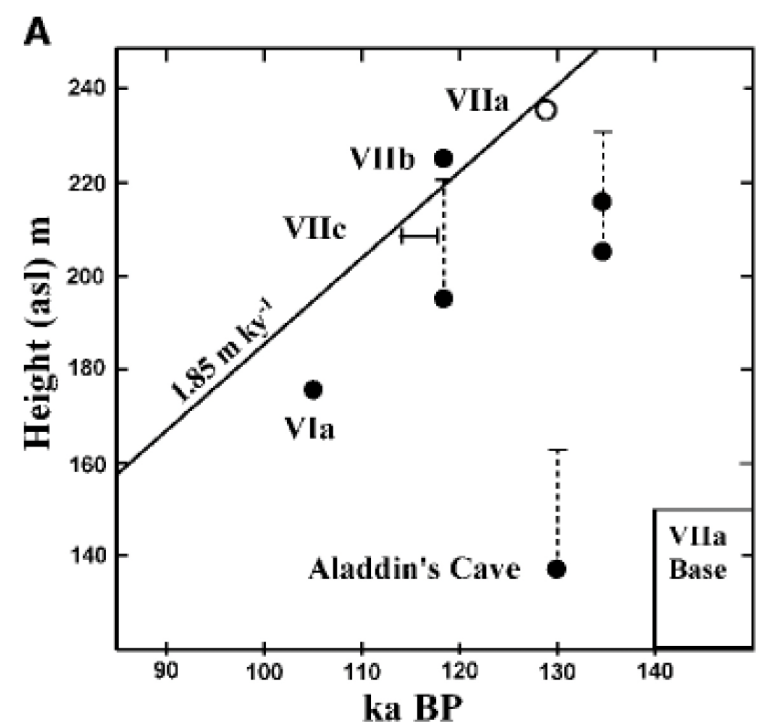

B

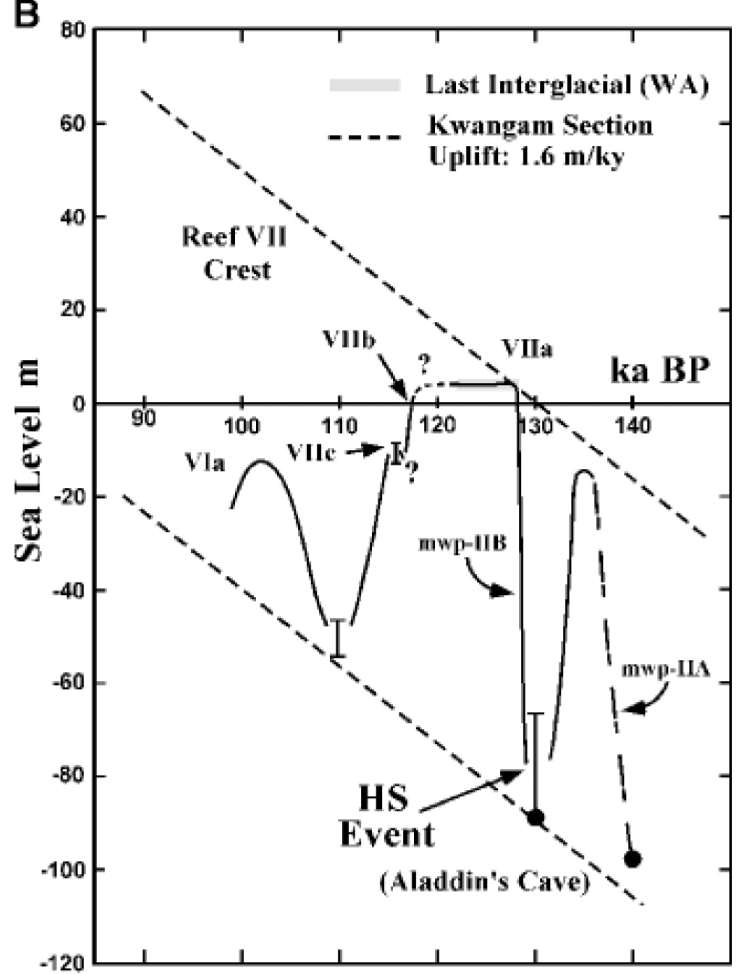

Figure 32. (a) The age-height relation for dated terraces at Kwambu that was constructed by assuming that the top of terrace VIIa at 118 to $120 \mathrm{ka}$ was 0 to $5 \mathrm{~m}$ above the present sea level. The dashed vertical lines indicate the possible range of water depth $(0$ to $20 \mathrm{~m}$ ) in which corals grew. (b) Eustatic sea-level curve for the penultimate deglacial period and the last interglacial. The smooth sea-level curve glosses over co-seismic uplift events at Huon Peninsula, which are discrete and metre scale and would not be discernible at this scale. The diagonal dashed lines represent the uplift with time for the crest of reef VII and Aladdin's Cave (from Esat et al., 1999).

\subsection{Mariana Islands}

Early studies in the 1940s to 1960s, including Stearns (1945), Tayama (1952), Cloud (1954), Cloud et al. (1956), Tracey et al. $(1959,1964)$ and Emery $(1962,1963)$, described Pleistocene reef terraces in the Mariana Islands. Benches have been described at different elevations on Saipan and Guam: at $+2,+5$ to +10 and $+20 \mathrm{~m}$ (Tayama, 1952$),+1.22$ to $+2.44 \mathrm{~m}$ (Emery, 1962) and $+1.52,+7.62,+13.72,+21.34$, and $+30.48 \mathrm{~m}$ (Stearns, 1945). The last interglacial Tanapag Limestone is usually found at elevations of less than $30 \mathrm{~m}$ (Weary and Burton, 2011). Muhs et al. (2020) carried out U-Th dating by high-precision thermal ionization mass spectrometry (TIMS) on coral samples from the Tanapag Limestone along the eastern and southern coasts of Saipan at elevations of about 13 to $30 \mathrm{~m}$. Twelve samples of Porites, Goniastrea and Acropora have been collected from four sites; of those nine are in a growth position (see Fig. 12b; Fig. 4 in Muhs et al., 2020). Ten samples of these corals at elevations of +9 to +14 m MSL have been dated at $125.7 \pm 1.2$ to $136.4 \pm 1.1 \mathrm{ka}$ (WALIS U-series IDs 3140 3146, 3149-3152; WALIS RSL IDs 3963, 3964, 3966), and two Goniastrea (growth position uncertain) at an elevation of $+23 \pm 3 \mathrm{~m}$ MSL have been dated at $126.9 \pm 0.9$ and $128.7 \pm 1 \mathrm{ka}$ (WALIS U-series IDs 3147,3148 ; WALIS RSL ID 3965). All samples, except one, contain less than $3 \%$ of calcite and the ages can be considered reliable and have been accepted. Porites, Goniastrea and Acropora are living in modern environments at median and average depths of 0 and 18.5, 6 and 15.3, and 4 and $5.7 \mathrm{~m}$, respectively.

The Mariana Islands are affected by uplift, but the rates are negligible in the Mariana arc (Yonekura, 1983). Miklavič et al. (2012) concluded an average uplift rate of about 0.1 to $0.2 \mathrm{~mm} / \mathrm{yr}$, and Muhs et al. (2020) reported low late Quaternary uplift rates of 0.002 to $0.19 \mathrm{~mm} / \mathrm{yr}$.

\subsection{Marshall Islands}

Data regarding the LIG from the Marshall Islands have been obtained from drill cores. Szabo et al. (1985) presented alpha-counting $\mathrm{U}$-series datings from two drill cores on the reef flat of Enewetak, which have been collected during the PACE programme. Merulinidae in a coral-algal boundstone in core C-3 at a depth of $9.8 \mathrm{~m}$ revealed ages of $131 \pm 7$ and $132 \pm 7 \mathrm{ka}$ (WALIS U-series IDs 1780 and 1781; C$3 \mathrm{~A}$ and $\mathrm{C}-3 \mathrm{~B}$ ). Three Merulinidae samples from core C-4, a coral-foraminiferal-skeletal grainstone containing numerous corals and abundant Halimeda, at a depth of $14.9 \mathrm{~m}$ have been dated at $128 \pm 7,136 \pm 8$ and $129 \pm 8 \mathrm{ka}$ (WALIS Useries IDs 1782-1784; C-4A, C-4B and C-4C). The dated samples contain less than $3 \%$ of calcite, and the ages can be considered reliable. The elevation measurement method has not been reported, but the cores have probably been handlevelled and the elevations refer to MSL. Modern Merulinidae mainly live at water depths shallower than $30 \mathrm{~m}$ (WALIS 
RSL IDs 555 and 556). The subsidence rate of Enewetak has been estimated at $0.038-0.052 \mathrm{~mm} / \mathrm{yr}$ (Paulay and McEdward, 1990).

\subsection{Hawaii}

Emerged marine carbonate deposits are observed in several Hawaiian Islands, and palaeo-shorelines may have been affected by tsunamis and storms. The LIG Waimanalo Limestone fringes most of Oahu and consists of corals in a growth position, which are often overlain by marine coral-basalt conglomerates. Stearns (1935a, b, c) was the first to study Pleistocene shorelines on the islands of Oahu and Maui, describing benches at elevations of +6 to $+10.7 \mathrm{~m}$ related to the Late Pleistocene (Stearns, 1941). Beach deposits on Ulupau Head, Oahu, occur up to 10.7 to $12.2 \mathrm{~m}$ above present sea level (Stearns, 1935c; Wentworth and Hoffmeister, 1939).

Several studies have provided ages for the deposits of the Waimanalo Limestone on Oahu, and Rubin et al. (2000) provided ages for Hulopoe gravel coral clasts on Lanai.

LIG reef terraces on Oahu reach an elevation of up to 12.5 m MSL, and Veeh (1966) and Ku et al. (1974) have been the first to date these emerged terraces. Early studies by Veeh (1966), Ku et al. (1974) and Sherman et al. (1993) used the alpha-counting technique, and later studies by Muhs and Szabo (1994), Szabo et al. (1994) and McMurtry et al. (2010) used mass spectrometry. Muhs et al. (2002) performed additional datings with a higher precision at the Szabo et al. (1994) study sites using high-precision thermal ionization mass spectrometry (TIMS). Elevations have been mostly hand-levelled, and sometimes the elevation measurement method has not been reported, but the samples have been probably hand-levelled. Uplift of Oahu was first quantified by Ku et al. (1974).

Waimanalo LIG deposits have been dated from several sites around Oahu (see Fig. 13; Fig. 1 in McMurtry et al., 2010, and Fig. 1 in Szabo et al., 1994). Based on the depth distribution of their modern counterparts, the coral taxa described below indicate a median and average depth of 0 to $15.6 \mathrm{~m}$; however, Pocillopora displays a wide depth range (see Table 2). Cross sections for some of these sites are displayed in Fig. 33. Information on each site is provided below.

1. Kahuku Point (WALIS RSL ID 542). Eight Porites and Pocillopora, of those five in situ, at an elevation of $+1 \pm 1 \mathrm{~m} \mathrm{MSL}$ have been dated at $113 \pm 0.7$ to $137 \pm 11 \mathrm{ka}$ (alpha counting, $1 \sigma$ uncertainty) and more accurately at $122.1 \pm 1.3 \mathrm{ka}$ ( $1 \sigma$ uncertainty; WALIS Useries IDs 1221-1224, 1170, 1171, 1771, 1778; Ku et al., 1974; Szabo et al., 1994; Muhs et al., 2002). All ages have been accepted.

\section{Mokapu Point.}

a. WALIS RSL ID 543 contains Porites and Pocillopora, of which six are in situ, at an eleva- tion of $+9.5 \pm 2.5 \mathrm{~m} \mathrm{MSL}$ that have been dated at $123.2 \pm 2.6$ to $134 \pm 4 \mathrm{ka}(n=15$ accepted out of 20 ages; WALIS U-series IDs 1193, 1194, 12261239, 1761-1762, 1800-1801; Ku et al., 1974; Szabo et al., 1994; Muhs and Szabo, 1994; Muhs et al., 2002). Muhs and Szabo (1994) dated reworked Pocillopora from coral-bearing beach or sublittoral sands (WALIS U-series ID 1800) and marine conglomerates with coral cobbles and heads (WALIS U-series ID 1801).

b. WALIS RSL IDs 3979 and 3980 (Hearty et al., 2007) contain one Porites lobata from the lower reef at an elevation of $+4.9 \pm 0.5 \mathrm{~m}$ MSL that has been dated at $131.24 \pm 0.41 \mathrm{ka}$ (WALIS U-series ID 1169; not reported if in situ). Two in situ Pocillopora meandrina from the upper reef at an elevation of $+8.5 \pm 1.0 \mathrm{~m}$ MSL have been dated at $130.9 \pm 0.49 \mathrm{ka}$ (WALIS U-series IDs 1167,1168 ). Porites lobata and Pocillopora meandrina live at median and average depths of 0 and $19.2 \mathrm{~m}$ and 0 and $15.8 \mathrm{~m}$, respectively. Not all ages have been accepted.

3. Alala Point (WALIS RSL ID 539). Porites and one Pocillopora, not in situ or not reported if in situ, at an elevation of $+2.4 \pm 2 \mathrm{~m}$ MSL have been dated at $119.4 \pm 3$ to $134.5 \pm 1.4 \mathrm{ka}(n=6$ accepted out of 8 ages; WALIS U-series IDs 1172-1177, 1207, 1208; Szabo et al., 1994; Muhs et al., 2002).

4. Maunalua Bay (WALIS RSL ID 546). Porites and Pocillopora, not reported if in situ, at an elevation of $+7.1 \pm 1 \mathrm{~m} \mathrm{MSL}$ have been dated at $118 \pm 3$ to $121 \pm 7 \mathrm{ka}(n=4 ; 1 \sigma$ uncertainty; WALIS U-series IDs 1756-1759; Ku et al., 1974). All ages have been accepted.

5. Black Point (WALIS RSL ID 545). Porites, not reported if in situ, at an elevation of $+7 \pm 1 \mathrm{~m}$ MSL have been dated at $112 \pm 6$ to $128 \pm 8 \mathrm{ka}(n=8 ; 1 \sigma$ uncertainty; WALIS U-series IDs 1748-1755; Ku et al., 1974). All ages have been accepted. Porites lives at median and average depths of 0 and $18.5 \mathrm{~m}$, respectively, in modern environments.

6. Diamond Head (WALIS RSL ID 544). Porites and Pocillopora, not in situ or not reported if in situ, at an elevation of $+1.25 \pm 1.25 \mathrm{~m}$ MSL have been dated at $114.6 \pm 2.6$ to $137 \pm 11 \mathrm{ka}(n=7 ; 1 \sigma$ uncertainty; WALIS U-series IDs 1209, 1210, 1773-1777; Ku et al., 1974; Szabo et al., 1994). All ages have been accepted.

7. Barbers Point (WALIS U-series ID 1779). Sherman et al. (1993) dated a single in situ Porites lobata from a coral bafflestone at an elevation of $+3 \pm 3 \mathrm{~m}$ MSL revealing an (accepted) age of $115 \pm 10 \mathrm{ka}$. 


\section{Kahe Point.}

a. WALIS RSL ID 530 contains reworked Porites and Pocillopora and one in situ Leptoseris (WALIS U-series ID 1240) at an elevation of $+9.75 \pm 2.75 \mathrm{mMSL}$ that have been dated at $110.9 \pm 3.5$ to $134 \pm 4 \mathrm{ka}$ ( $n=14$ accepted out of 17 ages; WALIS U-series IDs 1188-1192, 12161220, 1240-1244, 1802, 1803; Szabo et al., 1994; Muhs and Szabo, 1994; Muhs et al., 2002; McMurtry et al., 2010). Two samples have been collected from coral-bearing conglomerates (WALIS U-series IDs 1802 and 1803; Muhs and Szabo, 1994).

b. WALIS RSL IDs 3976 and 3977 (Kahe Beach State Park; Hearty et al., 2007) contain two Porites lobata from the lower reef at an elevation of $+4.0 \pm 0.5 \mathrm{mMSL}$ that have been dated at $115.35 \pm 1.15 \mathrm{ka}$ and $118.31 \pm 0.89 \mathrm{ka}$ (WALIS U-series IDs 1163, 1164; not reported if in situ). One in situ Porites lobata from the upper reef at an elevation of $+9.0 \pm 0.5 \mathrm{~m} \mathrm{MSL}$ has been dated at $119.37 \pm 0.57 \mathrm{ka}$ (WALIS U-series ID 1165). Porites lobata lives at median and average depths of 0 and $19.2 \mathrm{~m}$. Not all ages have been accepted.

\section{Kaena Point State Park.}

a. WALIS RSL ID 540 includes Porites, Pocillopora and one Pavona, not in situ or not reported if in situ, at an elevation of $+2 \pm 2 \mathrm{mMSL}$ that have been dated at $115 \pm 6$ to $127.5 \pm 0.8 \mathrm{ka}$ ( $n=11$ accepted out of 13 ages; WALIS U-series IDs 1178-1187, 1214, 1215, 1760; Ku et al., 1974; Szabo et al., 1994; Muhs et al., 2002).

b. WALIS RSL ID 3978 (Makua Valley; Hearty et al., 2007) includes one in situ Porites lobata from the upper reef at an elevation of $+8.0 \pm 0.5 \mathrm{~m} \mathrm{MSL}$ that has been dated at $123.8 \pm 1.3 \mathrm{ka}$ (WALIS U-series ID 1166). Porites lobata lives at median and average depths of 0 and $19.2 \mathrm{~m}$. The age has been accepted; however, no calcite content has been reported.

10. East of Kaena Point (WALIS RSL ID 541). Porites and Pocillopora, of which eight are in situ, at an elevation of $+1.5 \pm 1.5 \mathrm{~m} \mathrm{MSL}$ have been dated at $110.5 \pm 3.8$ to $138 \pm 4 \mathrm{ka}$ ( $n=15$ accepted out of 22 ages; WALIS Useries IDs 1195-1206, 1211-1213, 1793-1799; Szabo et al., 1994; Muhs and Szabo, 1994; Muhs et al., 2002). Three samples have been collected from coral cobble conglomerates (WALIS U-series IDs 1797-1799; Muhs and Szabo, 1994).

Veeh (1966) studied several sites on Oahu, which are detailed in Veeh (1965). In situ Leptastrea at an elevation of $+2.25 \pm 1.25 \mathrm{~m}$ MLWS has been dated at $110 \pm 20$ to $140 \pm 30 \mathrm{ka}$ ( $n=4$; WALIS RSL ID 547; WALIS U-series IDs 1739-1741, 1743; OAHU2, OAHU5, OAHU9 and OAHU22). However, the use of the alpha-counting technique resulted in large age uncertainties. Leptastrea lives at median and average depths of 7 and $17 \mathrm{~m}$, respectively.

Emerged reef terraces on Oahu described in all reviewed studies reach an elevation of up to $+12.5 \mathrm{~m} \mathrm{MSL}$. The majority of ages were obtained from the first $4 \mathrm{~m}$ of the reef terraces, and they range between $110.5 \pm 3.8$ and $138 \pm 4 \mathrm{ka}$ ( $n=48$ accepted ages). The terrace at about $+7 \mathrm{~m}$ reveals ages of $112 \pm 6$ to $128 \pm 8 \mathrm{ka}$ ( $n=12$ accepted ages). The +9 to $+12 \mathrm{~m}$ terraces have been dated at $110.9 \pm 3.5$ to $134 \pm 4 \mathrm{ka}$ ( $n=29$ accepted ages). Sherman et al. (1993) deduced the occurrence of two highstands during the LIG. Szabo et al. (1994) reported on a LIG sea-level high stand on Oahu, which lasted about 17000 years from 114 to $131 \mathrm{ka}$. Based on corals in growth position, Szabo et al. (1994) estimated that RSL was at least $7 \mathrm{~m}$ higher than present at $131 \mathrm{ka}$ and remained higher until at least $115 \mathrm{ka}$. These authors mention a considerable 1-27 m depth range of living Porites and Pocillopora. Muhs et al. (2002) performed additional datings with a higher precision at the Szabo et al. (1994) study sites and confirmed the concept of a long LIG period on Oahu as proposed by Szabo et al. (1994). Muhs et al. (2002) performed additional datings with a higher precision at the Szabo et al. (1994) study sites and confirmed the concept of a long LIG on Oahu as proposed by Szabo et al. (1994). However, they did not report any evidence for two separate sea-level stands as concluded by Sherman et al. (1993). McMurtry et al. (2010) did not consider the age data by Szabo et al. (1994) (white triangles in Fig. 34) as they seem to be biased toward lower elevation estimates. Furthermore, these authors did not consider the ages of elevated deposits from stages $5 \mathrm{e}$ and 9 (coloured triangles) as they derived from energetic deposits related to storms or tsunamis rather than being elevated reefs with corals in growth position. Besides MIS 5, other interglacials from MIS 7 to 13 can be found in the coral reef record from Oahu. MIS 7 reefs have been documented around Oahu where they form a gently sloping nearshore submerged terrace (Sherman et al., 2014). The most reliable maximum elevation and the mean age for each highstand or terrace from Oahu is summarized in Fig. 34. The MIS 5 terrace, the Waimanalo formation, is usually found at an elevation of $+7.5 \mathrm{~m}$. Based on this dataset, a linear uplift for Oahu has been estimated at $0.060 \pm 0.001 \mathrm{~mm} / \mathrm{yr}$ over the past $500 \mathrm{kyr}$ (McMurtry et al., 2010), resulting in an uplift of about $7.5 \mathrm{~m}$ since $125 \mathrm{ka}$.

Uncertainties of elevation measurements and datings are often large and do not allow an accurate conclusion about the timing and magnitude of the LIG RSL on Oahu. Furthermore, taxa have not often been determined, and therefore, an accurate palaeo-RSL could not be reconstructed. Determinations at the genus level often allow only rough estimates of palaeo-RSL. 
(a) Alala Point:

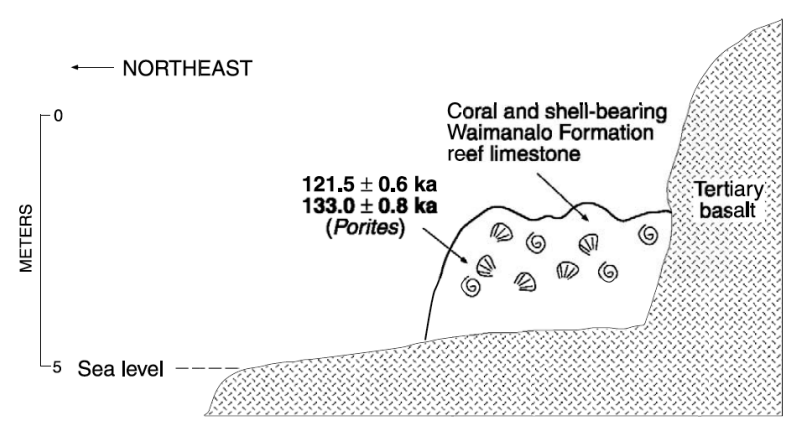

(c) North shore, east of Kaena Point: (b) Kahuku Point:

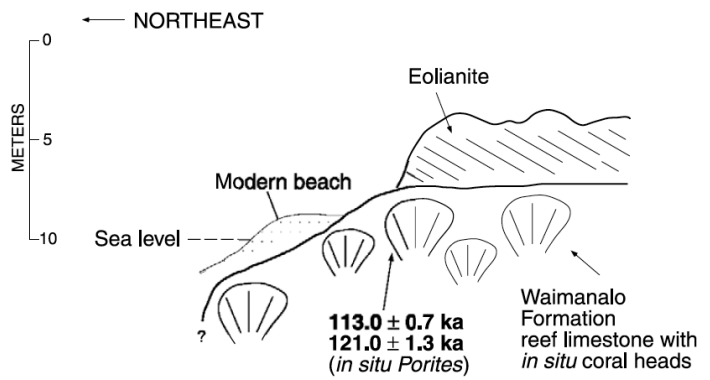

(d) Kahe Point:

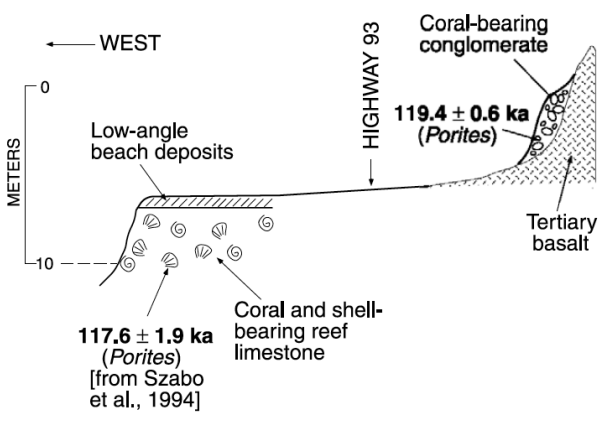

Figure 33. Cross sections of outcrops of the Waimanalo Formation exposed on (a) Alala Point, (b) Kahuku Point, (c) the north shore of Oahu east of Kaena Point and (d) Kahe Point along with reliable U-series ages of corals (from Muhs et al., 2002).

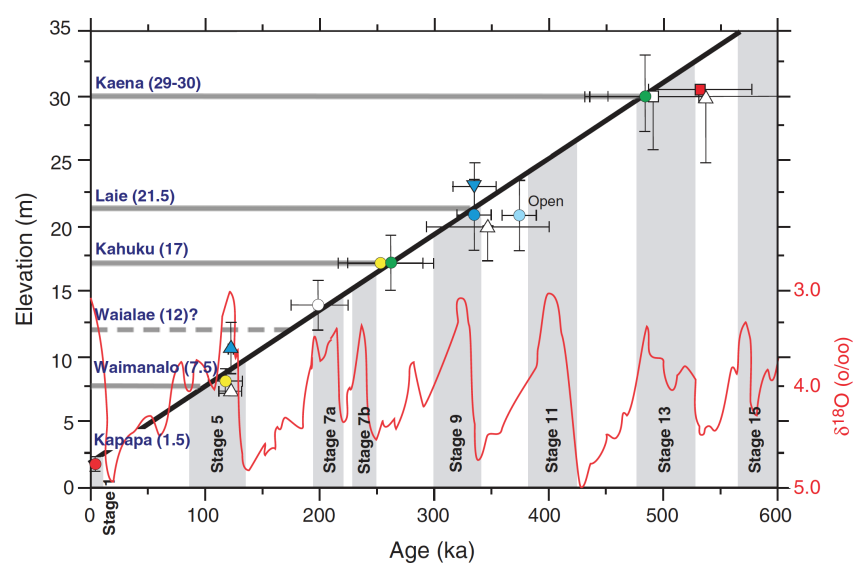

Figure 34. Mean or best ages versus maximum measured terrace elevation for known elevated reefs on Oahu (from McMurtry et al., 2010).
Rubin et al. (2000) provided high-precision TIMS Useries ages for emerged coral reef terraces on Lanai. These authors dated Hulopoe gravel coral clasts (no taxa determination, not in situ) at elevations of $+19.5 \pm 0.5 \mathrm{~m} \mathrm{MSL}$ and $+21 \pm 2 \mathrm{mMSL}$ and obtained ages of $130.9 \pm 1.5$ and $134.8 \pm 0.9 \mathrm{ka}$ (WALIS RSL ID 552; WALIS U-series IDs 1806 and 1807; Lan1-2h-1 and Lan3-6-2) as well as $136.4 \pm 0.9$ and $136.7 \pm 1.0 \mathrm{ka}$ (WALIS RSL ID 553; WALIS U-series IDs 1808 and 1809; Lan3-5-3 and Lan2-43 ), respectively. The dated samples contained less than $2.3 \%$ of calcite and the ages can be considered reliable. The elevation measurement method has not been reported, but the samples have probably been hand-levelled, and the elevations refer to MSL. A water depth range of $0-30 \mathrm{~m}$ has been assumed as no taxa identification has been reported. The mean uplift rate of Lanai has been estimated at $0.15 \pm 0.22 \mathrm{~mm} / \mathrm{yr}$ (Rubin et al., 2000). 


\section{Further details}

\subsection{Last interglacial sea-level fluctuations}

Studies regarding tropical Pacific islands have contributed to the long-lasting and ongoing debate regarding the course of the last interglacial (LIG) relative sea-level (RSL) curve, including the timing, duration and amplitude of the MIS 5e highstand. This is of prime importance for many tropical Pacific islands, as the elevation of the LIG peak has been considered a reference to assess rates of vertical displacement, uplift or subsidence.

The occurrence of two sea-level peaks during the LIG highstand was inferred from the study of LIG reef terraces from various tropical Pacific islands: Papua New Guinea (Chappell and Veeh, 1978), Vanuatu (Jouannic et al., 1982), Fiji (Nunn and Omura, 1999; Nunn et al., 2002) and Hawaii (Sherman et al., 1993) and, since then, in a number of regions, including the Caribbean (Blanchon et al., 2009; Thompson et al., 2011), even if the timing of this event is not always substantiated by radiometric ages (see Camoin and Webster, 2015).

In Papua New Guinea, ages obtained on the VIIa and VIIb terraces, which correspond to fringing and barrier reefs, respectively (Bloom et al., 1974; Chappell, 1974), fall into two tight groups centred at 118 and $134 \mathrm{ka}$. These two age clusters are separated vertically by $7 \mathrm{~m}$, thus indicating that the RSL at $136 \mathrm{ka}$ could have been $43 \mathrm{~m}$ lower than at $118 \mathrm{ka}$, given the $1.9 \mathrm{~mm} / \mathrm{yr}$ uplift rate (Stein et al., 1993). The conflict between samples from Aladdin's Cave (about $100 \mathrm{~m}$ above present mean sea level (MSL) and about $130 \mathrm{ka}$ ) and from the coral reef terrace VII (up to $220 \mathrm{~m}$ above present MSL and about $134 \mathrm{ka}$ ) has been explained by a sea-level drop of 60 to $80 \mathrm{~m}$ after the development of the reef terrace VIIb (Esat et al., 1999). A new rise in sea level after $130 \mathrm{ka}$ is deduced from the dataset and occurred in response to the major insolation maximum at 126 to $128 \mathrm{ka}$ (Esat et al., 1999). The 118 ka corals of reefs VIIa and VIIb may have also been deposited during an episode of sea-level rise at the end of the LIG (Esat et al., 1999).

On Vanuatu, the duplication of the MIS 5e terrace in the Port Havannah area displays striking similarities with the distribution of VIIa and VIIb reef terraces from Papua New Guinea (Bloom et al., 1974; Chappell, 1974) and has been interpreted as resulting from low-amplitude sea-level fluctuations during MIS 5e (Jouannic et al., 1982).

On Fiji Islands, the age distribution is thought to reflect a double sea-level maximum with peaks around 133-130 and 123-120 ka (Nunn et al., 2002). The earlier maximum has been reported about $2 \mathrm{~m}$ lower than the later maximum and marked by the growth of a surface reef, with the later maximum appearing to have involved only cutting of erosional shorelines at the +5.0 to $+5.5 \mathrm{~m}$ level (Nunn and Omura, 2003).
The occurrence of two separate sea-level highstands on Oahu during the LIG has been considered by Sherman et al. (1993). In contrast, the concept of a long LIG period of about 17000 years, from 114 to $131 \mathrm{ka}$, on Oahu has been proposed by Szabo et al. (1994) and later confirmed by Muhs et al. (2002). This concept involves an apparent local sea-level position $7 \mathrm{~m}$ higher than its current one by $131 \mathrm{ka}$, which remained higher than present until at least $115 \mathrm{ka}(\mathrm{Sz}-$ abo et al., 1994).

On the Cook Islands, Woodroffe et al. (1991) did not observe two periods of high RSL separated by a period of lower RSL during the LIG. However, they describe several stratigraphic features, such as erosional benches and notches, that might indicate RSL fluctuations during MIS 5e. However, these fluctuations have not been substantiated by chronological results.

On Saipan, Northern Mariana Islands, no evidence has been found for the occurrence of two sea-level peaks during the LIG (Muhs et al., 2020).

\subsection{MIS 5a and MIS 5c}

Since our database is specifically focused on MIS 5e reef records, Table 5 lists data concerning MIS 5a and 5c, which were obtained on tropical Pacific islands but not inserted in our database. These data might be useful for future research on MIS 5 shorelines in tropical Pacific regions and are reported in this description paper for completeness.

\subsection{Other interglacials}

Table 6 includes data concerning the description and/or the dating of other Pleistocene interglacial periods on tropical Pacific islands from a number of studies. These data are not included in our database, which concerns only MIS 5e reef records, but are of pivotal importance for further projects dealing with the reconstruction of sea-level changes and shoreline evolution during the Pleistocene in tropical Pacific islands.

\subsection{Holocene sea-level indicators}

Table 7 summarizes data concerning Holocene sea-level records from tropical Pacific islands. It especially includes results obtained on a mid-Holocene RSL highstand that appears as a significant feature in this region (Grossman et al., 1998; Dickinson, 2001, 2003, 2004; Woodroffe and Horton, 2005; Nunn, 2007; Hallmann et al., 2018). Studies of Holocene sea-level indicators for the reviewed islands are listed chronologically. These data are not inserted in our database, which specifically concerns MIS 5e reef records of RSL changes. 
Table 5. MIS 5a and MIS 5c reviewed in this study.

\begin{tabular}{|c|c|c|}
\hline Region & Sub-region/site & Description \\
\hline \multirow[t]{6}{*}{ Vanuatu } & Malakula & $\begin{array}{l}5 \mathrm{c} \text { terrace at }+204 \mathrm{~m} \text { with an age of } 107.6 \pm 1.1 \mathrm{ka} \text { (Cabioch and } \\
\text { Ayliffe, 2001). } \\
\text { Terrace at }+30 \mathrm{~m} \text { with an age of } 98 \pm 11 \mathrm{ka} \text {. The terrace is assumed to } \\
\text { correspond to the } 103 \mathrm{ka} \text { palaeo-RSL. } \\
\text { Terraces correspond to } 82 \text { and } 103 \mathrm{ka} \text { terraces from Bloom et al. (1974) } \\
\text { (Jouannic et al., 1980, 1982). }\end{array}$ \\
\hline & Efate & $\begin{array}{l}\text { Terrace at }+80 \mathrm{~m} \text { dated at } 106.4 \pm 6.4 \mathrm{ka} \text { BP and at } 103.5 \mathrm{ka} \text { (Tututuk } \\
\text { area; Lecolle and Bernat, 1985). } \\
\text { Terraces correspond to } 82 \text { and } 103 \mathrm{ka} \text { terraces from Bloom et al. (1974) } \\
\text { (Lecolle and Bernat, } 1985 \text {; Jouannic et al., 1982). } \\
\text { Terrace at }+70 \mathrm{~m} \text { dated at } 108 \mathrm{ka} \text { (Pangona area; Lecolle and Bernat, } \\
\text { 1985). } \\
\text { Terrace at }+20 \mathrm{~m} \text { dated at } 107.9 \mathrm{ka} \text { (Siviri area; Lecolle and Bernat, } \\
\text { 1985). }\end{array}$ \\
\hline & Santo & $\begin{array}{l}\text { Terraces correspond to } 82 \text { and } 103 \text { ka terraces from Bloom et al. (1974) } \\
\text { (Jouannic et al., 1980, 1982). }\end{array}$ \\
\hline & Malo & $\begin{array}{l}\text { Terraces correspond to } 82 \text { and } 103 \text { ka terraces from Bloom et al., } 1974 \\
\text { (Jouannic et al., 1982). }\end{array}$ \\
\hline & Hiw, Tegua, Loh, Toga & $\begin{array}{l}\text { Terraces correspond to } 82 \text { and } 103 \text { ka terraces from Bloom et al. (1974) } \\
\text { (Taylor et al., 1985). These reefs probably correspond, respectively, to } \\
\text { the } 80 \text { and } 103 \text { ka reefs on New Guinea and Barbados. }\end{array}$ \\
\hline & Tanna & Terraces attributed to stages 5a, 5b and 5c (Neef et al., 2003). \\
\hline \multirow[t]{3}{*}{ New Caledonia } & Lifou & Terrace at $+2.2 \mathrm{~m}$ dated at $90 \pm 4 \mathrm{ka}$ (Bernat et al., 1976). \\
\hline & Maré & $\begin{array}{l}\text { Terrace at }+2 \text { to }+5 \mathrm{~m} \text { gave ages of the order of } 90-98 \mathrm{ka} \text { (Bernat et al., } \\
\text { 1976). }\end{array}$ \\
\hline & $\begin{array}{l}\text { Grande Terre (Amédée } \\
\text { drill cores) }\end{array}$ & $\begin{array}{l}\text { Unit } 10 \text { (37 to } 14 \mathrm{~m} \text { b.s.1.) assigned to MIS } 5 \text { (100 to } 130 \mathrm{ka} \text {; Cabioch et } \\
\text { al., 2008). }\end{array}$ \\
\hline Papua New Guinea & & $\begin{array}{l}\text { Prominent reef terrace of reef complex V dated at } 85 \mathrm{ka} \text { (Bloom et al., } \\
\text { 1974). } \\
\text { Reef terraces V, VI and VIIb taken as } 82,103 \text { and } 124 \mathrm{ka} \text { (Bloom et al., } \\
\text { 1974). } \\
\text { High RSL at } 105 \mathrm{ka} \text { (Chappell, } 1974 \text { ). } \\
\text { Reef terraces V and VI dated at } 85 \pm 1.4 \mathrm{ka} \text { and } 107 \pm 7.5 \mathrm{ka} \text {, respec- } \\
\text { tively (Aharon and Chappell, 1986). } \\
\text { Reef crest VIa assumed to have formed at } 105 \mathrm{ka} \text { at } 10 \mathrm{~m} \text { below the } \\
\text { present MSL (Esat et al., 1999). } \\
\text { MIS } 5 \mathrm{~b} \text { RSL was }-57 \mathrm{~m} \text { at } 92.6 \pm 0.5 \mathrm{ka} \text {; drop of about } 40 \mathrm{~m} \text { in ap- } \\
\text { proximately } 10 \mathrm{kyr} \text { during MIS } 5 \mathrm{c}-5 \mathrm{~b} \text { transition. Sea-level rise more } \\
\text { than } 40 \mathrm{~m} \text { during the MIS } 5 \mathrm{~b}-5 \mathrm{a} \text { transition, also in about } 10 \mathrm{kyr} \text { MIS } 5 \mathrm{a} \\
\text { lasted until at least } 76.2 \pm 0.4 \mathrm{ka} \text {, at a level of }-24 \mathrm{~m} \text { at that time (Cutler } \\
\text { et al., 2003). }\end{array}$ \\
\hline Hawaii & Oahu & $\begin{array}{l}\text { Presence of MIS 5a and/or 5c on Oahu (Sherman, 1999). } \\
\text { Presence of MIS 5a-d on Oahu (Sherman et al., 2014). }\end{array}$ \\
\hline
\end{tabular}


Table 6. Other interglacials reviewed in this study.

\begin{tabular}{|c|c|c|}
\hline Region & Sub-region/site & Description \\
\hline \multirow[t]{2}{*}{ French Polynesia } & Moruroa & $\begin{array}{l}\text { MIS } 7 \text { and } 9 \text { reported (Camoin et al., 2001; Braithwaite and Camoin, } \\
\text { 2011) }\end{array}$ \\
\hline & Takapoto & MIS 7 and 9 reported (Montaggioni et al., 2019a) \\
\hline \multirow[t]{2}{*}{ Cook Islands } & $\begin{array}{l}\text { Atiu, Mauke, Mitiaro, } \\
\text { Mangaia }\end{array}$ & MIS 7 reported (Woodroffe et al., 1991) \\
\hline & Pukapuka, Rakahanga & MIS 7, 9, 11, 13 and 15 indicated (Gray et al., 1992) \\
\hline Niue & & MIS 7 reported (Kennedy et al., 2012) \\
\hline Tonga & Tongatapu & MIS 7 probably present (Taylor and Bloom, 1977) \\
\hline Fiji & Kadavu, Kaibu & $\begin{array}{l}\text { Reef terrace at }+3.2 \text { to }+4.8 \mathrm{~m} \text { dated from } 223 \pm 7.6 \text { to } 207.2 \pm 5.9 \mathrm{ka} \\
\text { on Kadavu Island (Nagigia area; Nunn and Omura, 1999). These dates } \\
\text { may indicate that the two reefs cannot be considered separate entities } \\
\text { and that the Nagigia reef is thus interpreted as having grown upwards to } \\
\text { a RSL at least } 7.1 \mathrm{~m} \text { higher than present MSL, perhaps ca. } 208 \mathrm{ka} \text {. Nunn } \\
\text { and Omura (2003) have considered that, in the absence of U-series ages, } \\
\text { the two higher terraces on Kaibu Island, at } 8.0-9.2 \text { and } 12-14 \mathrm{~m} \text {, could } \\
\text { have formed during MIS } 7 \text { RSL maxima. }\end{array}$ \\
\hline Tuvalu & Funafuti & $\begin{array}{l}\text { Reef sequence between } 27 \text { and } 58 \mathrm{~m} \text { core depth in Funafuti drill cores } \\
\text { attributed to MIS } 7 \text {. A Sr isotope age of } 0.21 \pm 0.21 \mathrm{Ma} \text { obtained on an } \\
\text { unidentified coral collected at } 36.6 \mathrm{~m} \text { below the reef surface (Ohde et } \\
\text { al., 2002). }\end{array}$ \\
\hline \multirow[t]{2}{*}{ Vanuatu } & Tanna & MIS 7 reported (Neef et al., 2003) \\
\hline & Futuna & MIS 7, 9, 11 and 13 (Neef and McCulloch, 2001) \\
\hline \multirow[t]{3}{*}{ New Caledonia } & Loyalty Islands & Terrace at $+2.5 \mathrm{~m}$ dated at ca $225 \mathrm{ka}$ (Bourrouilh-Le Jan, 1985) \\
\hline & $\begin{array}{l}\text { Grande Terre (Amédée } \\
\text { drill cores) }\end{array}$ & $\begin{array}{l}\text { MIS } 7 \text { and probably } 9 \text { or } 11 \text { (Frank et al., 2006) and MIS } 7 \text { (221 to } \\
248 \mathrm{ka} \text { ) relate to Unit } 9(40-37 \mathrm{~m} \text { core depth; Cabioch et al., 2008) }\end{array}$ \\
\hline & $\begin{array}{l}\text { Grande Terre (Ténia } \\
\text { drill cores) }\end{array}$ & $\begin{array}{l}\text { MIS } 7 \text { not identified; MIS } 9 \text { and probably MIS } 11 \text { and } 13 \text { reported } \\
\text { (Montaggioni et al., 2011) }\end{array}$ \\
\hline Papua New Guinea & & MIS 7 reported (Omura et al., 1994) \\
\hline Marshall Islands & Enewetak & MIS 7 or 9 , MIS 9 or 11 or 13 probably found (Szabo et al., 1985) \\
\hline \multirow[t]{2}{*}{ Hawaii } & Oahu & $\begin{array}{l}\text { MIS } 11,13 \text { or } 15 \text { probably present (Szabo et al., 1994) } \\
\text { MIS } 7 \text { reported (Sherman et al., 1999, 2014) } \\
\text { MIS } 11 \text { reported (Hearty, 2002) } \\
\text { MIS } 7,9 \text { and } 13 \text { reported; no evidence for MIS } 11 \text { (McMurtry et al., } \\
2010 \text { ) }\end{array}$ \\
\hline & Lanai, Moloka'i & MIS 7 reported (Rubin et al., 2000) \\
\hline
\end{tabular}

\subsection{Controversies}

Besides past debates regarding the course of the LIG RSL curve (see Sect. 6.1), the study of MIS 5e reefs on tropical Pacific islands has generated several controversies mostly related to the interpretation of reef terraces. For example, McMurtry et al. (2010) did not consider the ages obtained by Szabo et al. (1994) on the MIS 5e reef terrace on Oahu as they interpreted these deposits as being derived from ener- getic deposits related to storms or tsunamis rather than as corals in growth position. A similar controversial issue has concerned the interpretation of LIG deposits on Lanai seen as highstand deposits, then mega-tsunami deposits and eventually re-interpreted as highstand shoreline features deposited during the last two interglacials (see review in Webster et al., 2007). 
Table 7. Holocene sea-level indicators reviewed in this study.

\begin{tabular}{|c|c|}
\hline Region & References \\
\hline French Polynesia & $\begin{array}{l}\text { Lalou et al. (1966); Guilcher et al. (1969); Labeyrie et al. (1969); Montaggioni and Pirazzoli } \\
\text { (1984); Trichet et al. (1984); Montaggioni (1985); Pirazzoli et al. (1985a, b); Pirazzoli and Mon- } \\
\text { taggioni (1986); Pirazzoli (1987); Pirazzoli and Montaggioni (1987); Pirazzoli et al. (1987); } \\
\text { Pirazzoli and Montaggioni (1988); Pirazzoli et al. (1988a, b); Camoin et al. (2001); Braithwaite } \\
\text { and Camoin (2011); Rashid et al. (2014); Gischler et al. (2016); Hallmann et al. (2018); Gischler } \\
\text { et al. (2019); Montaggioni et al. (2019b); Hallmann et al. (2020) }\end{array}$ \\
\hline Cook Islands & $\begin{array}{l}\text { Schofield (1970); Stoddart (1972, 1975); Scoffin et al. (1985); Spencer et al. (1988); Yonekura } \\
\text { et al. (1988); Woodroffe et al. (1990, 1991); Allen (1992); Gray et al. (1992); Ellison (1994); } \\
\text { Yonekura (1994); Chikamori (1996); Allen (1998); Chikamori (1998, 2001); Moriwaki et } \\
\text { al. (2006); Goodwin and Harvey (2008); Allen et al. (2016) }\end{array}$ \\
\hline Samoa & $\begin{array}{l}\text { Mayor (1921, 1924); Stearns (1944); Kear and Wood (1959); Fairbridge (1961); Grant-Taylor } \\
\text { and Rafter (1962); Shepard (1963); Stice and McCoy (1968); Matsushima et al. (1984); Rodda } \\
\text { (1988); Sugimura et al. (1988a); Nunn (1991); Goodwin and Grossman (2003) }\end{array}$ \\
\hline Niue & Schofield (1959); Paulay and Spencer (1992); Nunn and Britton (2004); Kennedy et al. (2012) \\
\hline Tonga & $\begin{array}{l}\text { Taylor and Bloom (1977); Kirch (1978); Taylor (1978); Ellison (1988); Nunn (1991); Dickinson } \\
\text { et al. (1994), Nunn (1994, 1995a); Nunn and Finau (1995); Spenneman (1997) }\end{array}$ \\
\hline Fiji & $\begin{array}{l}\text { Taylor (1978); Berryman (1979); Green (1979); Rodda (1986); Ash (1987); Miyata et al. (1988); } \\
\text { Nunn (1988); Roy (1988); Sugimura et al. (1988b); Miyata et al. (1990); Nunn (1990a, b); } \\
\text { Shepard (1990); Nunn (1995b); Spriggs (1997); Nunn (2000); Nunn et al. (2000); Nunn and } \\
\text { Peltier (2001); Thomas et al. (2004); Mörner and Matlack-Klein (2017) }\end{array}$ \\
\hline Tuvalu & $\begin{array}{l}\text { David and Sweet (1904); Schofield (1977a); Kaplin (1981); McLean and Hosking (1991); Dick- } \\
\text { inson (1999); Ohde et al. (2002) }\end{array}$ \\
\hline Kiribati & $\begin{array}{l}\text { Tracey (1972); Schofield (1977a, b); Marshall and Jacobson (1985); Woodroffe and McLean } \\
\text { (1998); Woodroffe and Morrison (2001); Woodroffe et al. (2012); Yamano et al. (2017) }\end{array}$ \\
\hline Solomon Islands & Kirch and Yen (1982); Thirumalai et al. (2015) \\
\hline Vanuatu & Jouannic et al. (1980, 1982); Taylor et al. (1985); Cabioch and Ayliffe (2001); Neef et al. (2003) \\
\hline New Caledonia & $\begin{array}{l}\text { Baltzer (1970); Coudray and Delibrias (1972); Bourrouilh-Le Jan (1985); Cabioch et al. (1989, } \\
\text { 1995); Frank et al. (2006); Cabioch et al. (2008); Wirrmann et al. (2011) }\end{array}$ \\
\hline Papua New Guinea & $\begin{array}{l}\text { Chappell and Polach (1972, 1991); Ota et al. (1993); Chappell (1994); Chappell et al. (1996); } \\
\text { Riker-Coleman et al. (2006) }\end{array}$ \\
\hline Federated States of Micronesia & $\begin{array}{l}\text { Wiens (1962); Shepard et al. (1967); Tracey (1968); Curray et al. (1970); Bloom (1970); Newell } \\
\text { and Bloom (1970); Leach and Ward (1981); Matsumoto et al. (1986); Athens (1995); Kawana } \\
\text { et al. (1995); Fujimoto et al. (1996) }\end{array}$ \\
\hline Mariana Islands & $\begin{array}{l}\text { Kuenen (1933); Stearns (1941); Cloud et al. (1956); Tracey et al. (1964); Curray et al. (1970); } \\
\text { Easton et al. (1978); Randall and Siegrist (1988); Kayanne et al. (1993) }\end{array}$ \\
\hline Marshall Islands & $\begin{array}{l}\text { Wiens (1962); Thurber et al. (1965); Shepard et al. (1967); Curray et al. (1970); Newell and } \\
\text { Bloom (1970); Tracey and Ladd (1974); Buddemeier et al. (1975); Dickinson (1999); Kayanne } \\
\text { et al. (2011) }\end{array}$ \\
\hline Hawaii & $\begin{array}{l}\text { Stearns (1941); Gross et al. (1969); Ladd et al. (1970); Stearns (1974); Easton and Olson } \\
\text { (1976); Athens and Ward (1991); Fletcher and Jones (1996); Allen (1997); Athens (1997); } \\
\text { Grigg (1998); Grossman and Fletcher (1998); Matsumoto et al. (1988); Jones (1992, 1998); } \\
\text { Calhoun and Fletcher (1996); Rubin et al. (2000); Carson (2003, 2004); Nunn et al. (2007) }\end{array}$ \\
\hline
\end{tabular}




\subsection{Uncertainties and data quality}

Overall, the database contains 318 age data points summarized in 94 RSL indicators and based on 38 studies on MIS 5 e coral reef records in the tropical Pacific. One key aspect concerning the data quality is that 25 studies are older than 20 years, and 14 studies are even older than 30 years. This impacts the quality of elevation measurements and the age information as methods improved considerably over the last decades. The data quality is mostly affected by the quality of the RSL data and, to a lesser extent, by the quality of age information. Tables 8 and 9 summarize the evaluation of the RSL data and the age information quality.

No study related to LIG reef systems from the tropical Pacific islands includes a detailed description of in situ reef assemblages. Over the last 2 decades, in situ reef assemblages, including corals and associated biota (i.e. coralline algae, vermetid gastropods and encrusting foraminifera) rather than monospecific coral communities have increasingly been used to more accurately constrain palaeo-water-depths as well as other important palaeo-environmental parameters in the study of last deglacial and Holocene reef sequences (see review in Camoin and Webster, 2015). Large RSL uncertainties and limitations in the accuracy of RSL reconstructions can be considered for studies concerning MIS 5e coral reef records from the tropical Pacific islands. In addition, sedimentological and morphological data are barely described, thus hampering the accurate reconstruction of the relevant reef systems.

About $83 \%$ of the data points reveal a very poor RSL quality as the coral taxa have been determined only at the genus (about $67 \%$ of the data points) or family (about $10 \%$ of the data points) level. For about $13 \%$ of the data points no coral taxa have been reported at all. This introduces very large RSL uncertainties of $\pm 7-15 \mathrm{~m}$ and excludes any constraint regarding the RSL position during MIS 5e. Some coral genera, e.g. Porites and Pocillopora that are the most commonly studied genera, display wide depth ranges in modern environments with median-average depths of $0-18.5$ and $0-15.6 \mathrm{~m}$, respectively, thus precluding an accurate RSL reconstruction. An additional $10 \%$ of the data points reveal a poor RSL quality with final RSL uncertainties of more than $3 \mathrm{~m}$. Only fewer than $10 \%$ of the RSL data are of an average or good quality with final RSL uncertainties between 1 and $3 \mathrm{~m}$. These data are based on coral genera, e.g. Leptoria, which live at narrower depth ranges and can therefore be used to reconstruct RSL with uncertainties of about $\pm 2 \mathrm{~m}$. Consequently, about $90 \%$ of the RSL information is not reliable and does not allow accurate RSL reconstructions during MIS 5e. Coral assemblages would need to be identified carefully, and their palaeo-water-depth significance determined accurately. Special attention should be given to RSL indicators typified by a narrow depth range to better constrain RSL reconstructions.

Age information quality of the data points is significantly higher than their RSL quality. Age information of $39 \%$ of the data points is of excellent quality; i.e. ages have been accurately measured with very narrow age ranges and uncertainties of up to $\pm 2 \mathrm{ka}$. About $28 \%$ of the data points are still of good to average quality concerning the age information. "Good quality" means that the ages of the coral samples could be determined with narrow age ranges and uncertainties of $\pm 2-4 \mathrm{ka}$, allowing the attribution to a specific substage of MIS 5. "Average quality" refers to ages with uncertainties of $\pm 4-15 \mathrm{kyr}$ so that the RSL data point can be attributed only to a generic interglacial (e.g. MIS 5). The use of the alpha-counting technique resulted in large age uncertainties $( \pm 4-20 \mathrm{kyr})$. Based on this method, $32 \%$ of the ages reveal large uncertainties with more than $\pm 15 \mathrm{kyr}$. Ages have been accepted in $54 \%$ of the original studies, $46 \%$ of the ages have not been accepted and for the data points it is not known. A further problem is that the preservation of the samples is often unknown, implying that the reliability of the ages presented in the reviewed studies cannot be addressed. Only $41 \%$ of the studies report a calcite content of less than $3 \%$; i.e. the samples are well preserved and the obtained ages can be considered reliable. About $57 \%$ of the studies do not mention the preservation of the dated coral samples, so that the published age cannot be confirmed.

Another source of uncertainties is inaccurate elevation measurements. Many studies used hand levelling and metered tape to determine the elevations of coral samples, resulting in uncertainties of about $\pm 0.5-1 \mathrm{~m}$. Some studies did not even report elevations, and thus they had to be extracted from published sketches, which introduced large uncertainties. Overall, the elevation uncertainties are significant and might be up to $2-4 \mathrm{~m}$, but they are still overprinted by the very large palaeo-water-depth uncertainties introduced by the common lack of accurate studies of coral assemblages. Accurate GPS measurements would be needed to better constrain the elevation of RSL indicators.

A further important aspect for sea-level studies is that the corals need to be in growth position and in situ to provide reliable information on past sea levels. However, for about $65 \%$ and $51 \%$ of the data points, the original studies do not mention whether the dated corals have been collected in growth position or in situ, respectively. This introduces large uncertainties, even when these corals have been accurately dated, as they cannot therefore be considered reliable sealevel indicators.

The overall quality of this database is very poor mainly due to the poorly constrained palaeo-water-depth range of coral assemblages, which introduces the largest uncertainty. The inaccuracy of elevation measurements, the lack of information on coral preservation and the poor/missing information regarding the coral occurrence in LIG reefs introduce additional biases. Future work using more accurate dating methods and elevation measurements as well as a more detailed identification of the collected coral samples is essential to better constrain the MIS 5e RSL dataset concerning the tropical Pacific islands. 
Table 8. Evaluation of the RSL data quality.

\begin{tabular}{ll}
\hline Description & Quality rating \\
\hline Final RSL uncertainty is between 1 and $2 \mathrm{~m}$. & 4 (good) \\
Final RSL uncertainty is between 2 and $3 \mathrm{~m}$. & 3 (average) \\
Final RSL uncertainty is higher than $3 \mathrm{~m}$. & 2 (poor) \\
Taxa determination only at the genus or family level with a large modern depth range. Final & 1 (very poor) \\
RSL uncertainty is very large, higher than $7 \mathrm{~m}$. & 1 (very poor) \\
No taxa determination. Final RSL uncertainty is very large, about $15 \mathrm{~m}$. & \\
\hline
\end{tabular}

Table 9. Evaluation of the age information quality.

\begin{tabular}{ll}
\hline Description & Quality rating \\
\hline Accurate age determination with a very narrow age range and uncertainties of up to \pm 2 kyr. & 5 (excellent) \\
Narrow age range and uncertainties of $\pm 2-4$ kyr allowing the attribution to a specific substage of MIS 5. & 4 (good) \\
With uncertainties of $\pm 4-15$ kyr the RSL data point can be attributed only to a generic interglacial (e.g. MIS 5). & 3 (average) \\
Age determination using the alpha-counting technique results in large uncertainties with more than \pm 15 kyr. & 2 (poor) \\
\hline
\end{tabular}

\section{Data availability}

The database is available open access, and kept updated as necessary, at the following link: https://doi.org/10.5281/zenodo.3991672 (Hallmann and Camoin, 2020). The files at this link were exported from the WALIS database interface on 22 April 2021 and collated into a single .xls file from the different users who inserted them (Gilbert Camoin and Nadine Hallmann). A description of each field in the database is contained at this link: https://doi.org/10.5281/zenodo.3961543 (Rovere et al., 2020), which is readily accessible and searchable here: https://walis-help.readthedocs.io/en/latest/ (last access: 22 April 2021). More information on the World Atlas of Last Interglacial Shorelines can be found here: https://warmcoasts.eu/world-atlas.html (last access: 22 April 2021). Users of our database are encouraged to cite the original sources alongside our database and this article.

\section{Future research directions}

RSL change reconstructions require the combination of reliable radiometric ages and elevation measurements, as well as an accurate estimate of palaeo-water-depths deduced from the modern distribution of relevant reef communities (see review in Camoin and Webster, 2015). Our newly compiled database (Hallmann and Camoin, 2020) demonstrates that most of the studies that have been carried out on tropical Pacific islands do not satisfy these requirements, thus hampering the accurate reconstruction of LIG RSL history. This implies that these LIG reef systems will have to be studied in more detail with such a perspective.

Future research directions may therefore require a revisit of LIG reef records from tropical Pacific islands, especially the key "reference sites" (e.g. Papua New Guinea, Hawaii,
Vanuatu), in order to collect the missing information that is crucially needed to properly reconstruct LIG RSL changes.

More accurate constraints on the timing, duration and amplitude of the highstand are pivotal to better constrain glacial isostatic adjustments during the LIG. In addition, despite the extensive literature on LIG RSL changes, only a few papers have tried to estimate suborbital-scale interglacial RSL variability during that time window (see reviews in Dutton and Lambeck, 2012; Woodroffe and Webster, 2014; Camoin and Webster, 2015). Higher-resolution dating combined with accurate sedimentological studies of LIG reefs will be needed to decipher and reconstruct high-frequency RSL oscillations related to shorter climate excursions during the LIG period.

Finally, the full understanding of the impact of RSL changes at various timescales on LIG reef growth will require the study of reef development patterns that have so far been barely investigated. Facies sequences are also an important component to reconstruct sea-level change and have been considered in parallel to the analysis of reef assemblages in many studies focused on last deglacial and Holocene reefs from the Indo-Pacific (see Camoin and Webster, 2015, and references therein).

The standardized MIS 5e database provides an excellent tool for future LIG sea-level research as any missing information can be added to the WALIS database at a later stage for a more accurate reconstruction of MIS 5e RSL changes.

Author contributions. $\mathrm{NH}$ and GC wrote the manuscript and compiled the database; $\mathrm{MH}$ provided the palaeo-water-depth significance of coral assemblages; $\mathrm{MH}$ and JMW contributed to the manuscript during the final stage; $\mathrm{NH}$ produced the figures. 
Competing interests. The authors declare that they have no conflict of interest.

Special issue statement. This article is part of the special issue "WALIS - the World Atlas of Last Interglacial Shorelines". It is not associated with a conference.

Acknowledgements. The data used in this study were compiled in WALIS, a sea-level database interface developed by the ERC Starting Grant "WARMCOASTS" (ERC-StG-802414), in collaboration with PALSEA (PAGES/INQUA) working group. The database structure was designed by Alessio Rovere, Deirdre Ryan, Thomas Lorscheid, Andrea Dutton, Peter Chutcharavan, Dominik Brill, Nathan Jankowski, Daniela Mueller, Melanie Bartz, Evan Gowan and Kim Cohen. The data points used in this study were contributed to WALIS by Gilbert Camoin and Nadine Hallmann (163 age data points and 94 RSL indicators) and by Peter Chutcharavan (155 age data points). Basemap: "National Geographic Map", with data from National Geographic, Esri, Garmin, HERE, UNEPWCMC, USGS, NASA, ESA, METI, NRCAN, GEBCO, NOAA and INCREMENT P Corp (Figs. 5a, 6, 7a, 8a-b, 9-13). The authors gratefully acknowledge the guidance and support of the two editors Alessio Rovere and Alexander Simms as well as the two referees Clark Sherman and Blake Dyer for providing constructive comments.

Review statement. This paper was edited by Alexander Simms and reviewed by Clark Sherman and Blake Dyer.

\section{References}

Agassiz, A.: The coral reefs of the tropical Pacific, Bull. Mus. Comp. Zool., 28, 171-174, 1903.

Aharon, P.: $140000-y r$ isotope climatic record from raised coral reefs in New Guinea, Nature, 304, 720-723, 1983.

Aharon, P. and Chappell, J.: Oxygen isotopes, sea level changes and the temperature history of a coral reef environment in New Guinea over the last 105 years, Palaeogeogr. Palaeocl., 56, 337379, 1986.

Allen, J.: Pre-contact landscape transformation and cultural change in windward O'ahu, in: Historical Ecology in the Pacific Islands, edited by: Kirch, P. V. and Hunt, T. L., Yale University Press, New Haven, USA, 230-247, 1997.

Allen, M. S.: Dynamic Landscapes and Human Subsistence: Archaeological Investigations on Aitutaki Island, Southern Cook Islands, PhD thesis, University of Washington, Seattle, USA, 557 pp., 1992.

Allen, M. S.: Holocene sea-level change on Aitutaki, Cook Islands: landscape change and human response, J. Coastal Res., 14, 1022, 1998.

Allen, M. S., Morrison, A. E., Lorrey, A. M., Zhao, J.-X., and Jacobsen, G. E.: Timing, magnitude and effects of late Holocene sea level drawdown on island habitability, Aitutaki, Cook Islands, Archaeol. Ocean., 51, 108-121, 2016.
Anthony, S.: Hydrogeology and ground-water resources of Pingelap Island, Pingelap Atoll, State of Pohnpei, Federated States of Micronesia, Water-Resources Investigations Report 92-4005, U.S. Geological Survey, 40 pp., 1996 a.

Anthony, S.: Hydrogeology and ground-water resources of Kahlap Island, Mwoakilloa Atoll, State of Pohnpei, Federated States of Micronesia, Water-Resources Investigations Report 91-4184, U.S. Geological Survey, 44 pp., 1996 b.

Anthony, S.: Hydrogeology and ground-water resources of Ngatik Island, Sapwuahfik Atoll, State of Pohnpei, Federated States of Micronesia, Water-Resources Investigations Report 93-4117, U.S. Geological Survey, 44 pp., 1996c.

Anthony, S. and Spengler, S.: Geology and ground-water resources reconnaissance of Lenger Island, State of Pohnpei, Federated States of Micronesia, Water-Resources Investigations Report 934217, U.S. Geological Survey, 13 pp., 1996.

Ash, J.: Holocene sea levels in northern Viti Levu, Fiji, New Zeal. J. Geol. Geop., 30, 431-435, 1987.

Ash, R. P., Carney, J. N., and Macfarlane, A.: Geology of Efate and Offshore Islands, New Hebrides Geological Survey Regional Report, University of California, California, USA, 49 pp., 1978.

Athens, J. S.: Landscape archaeology: prehistoric settlement, subsistence, and environment of Kosrae, Eastern Caroline Islands, Micronesia, report prepared for the Kosrae State Government, Federated States of Micronesia, International Archaeological Research Institute, Honolulu, Hawaii, USA, 474 pp., 1995.

Athens, J. S.: Hawaiian native lowland vegetation in prehistory, in: Historical ecology in the Pacific Islands, edited by: Kirch, P. and Hunt, T. L., Yale University Press, New Haven, USA, 248-270, 1997.

Athens, J. S. and Ward, J. V.: Paleoenvironmental and archaeological investigations, Kawainui March flood control project, Oahu, U.S. Army Engineering Division, Pacific Ocean Environmental Section, Fort Shafter, Hawaii, International Archaeological Research Institute, Honolulu, Hawaii, USA, 129 pp., 1991.

Ayers, J. F. and Vacher, H. L.: Hydrogeology of an Atoll Island: A conceptual model from detailed study of a Micronesian example, Ground Water, 24, 185-198, 1986.

Ayling, B. F., Eggins, S., McCulloch, M. T., Chappell, J., Grün, R., and Mortimer, G.: Uranium uptake history, open-system behaviour and uranium-series ages of fossil Tridacna gigas from Huon Peninsula, Papua New Guinea, Geochim. Cosmochim. Ac., 213, 475-501, 2017.

Baltzer, F.: Datation absolue de la transgression holocène sur la côte Ouest de Nouvelle-Calédonie sur des échantillons de tourbes à palétuviers: Interprétation néotectonique, CR. Acad. Sci. Série D-Sciences Naturelles, 271, 2251-2254, 1970.

Bernat, M., Launay, J., and Recy, J.: Datation à l'ionium de quelques formations coralliennes emergées de NouvelleCalédonie et des Îles Loyauté, CR. Acad. Sci. Série D-Sciences Naturelles, 282, 9-12, 1976.

Berryman, K.: Seismotectonic zoning study of the Fiji Islands, New Zealand Geological Survey Report 70, 41 pp., 1979.

Blanchon, P., Eisenhauer, A., Fietzke, J., and Liebetrau, V.: Rapid sea-level rise and reef back-stepping at the close of the last interglacial highstand, Nature, 458, 881-884, 2009.

Bloom, A. L.: Paludal stratigraphy of Truk, Ponape, and Kusai, Eastern Caroline Islands, Geol. Soc. Am. Bull., 81, 1895-1904, 1970. 
Bloom, A. L., Broecker, W. S., Chappell, J., Matthews, R. K., and Mesolella, K. J.: Quaternary sea level fluctuations on a tectonic coast, New ${ }^{230} \mathrm{Th} /{ }^{234} \mathrm{U}$ dates from the Huon Peninsula, New Guinea, Quaternary Res., 4, 185-205, 1974.

Bloom, A. L., Jouannic, C., and Taylor, F. W.: Preliminary radiometric ages from the uplifted quaternary coral reefs of Efate, New Hebrides, in: Geology of Efate and Offshore Islands, New Hebrides Geological Survey Regional Report, edited by: Ash, R. P., Carney, J. N., and Macfarlane, A., University of California, California, USA, 47-49, 1978.

Bonney, T. G.: The atoll of Funafuti: Borings into a coral reef and the results, being the Report of the Coral Reef Committee of the Royal Society, The Royal Society of London, London, UK, 19 pp., 1904.

Bourrouilh-Le Jan, F. G.: An attempt at datation by isotopic stratigraphy of Holocene and Pleistocene notches of some so-called uplifted atolls (high carbonate islands), in: Proceedings of The Fifth International Coral Reef Congress, Tahiti, French Polynesia, 27 May-1 June 1985, 125-130, 1985.

Braithwaite, C. J. R. and Camoin, G. F.: Diagenesis and sea-level change: lessons from Moruroa, French Polynesia, Sedimentology, 58, 259-284, 2011.

Buddemeier, R. W., Smith, S. V., and Kinzie, R. A.: Holocene windward reef-flat history, Enewetok Atoll, Geol. Soc. Am. Bull., 86, 1581-1584, 1975.

Cabioch, G.: Récifs frangeants de Nouvelle-Calédonie (Pacifique sud-ouest), Structure interne et influences de l'eustatisme et de la néotectonique, $\mathrm{PhD}$ thesis, Université de Provence, Aix-enProvence, France, 291 pp., 1988

Cabioch, G. and Ayliffe, L. K.: Raised coral terraces at Malakula, Vanuatu, Southwest Pacific, indicate high sea level during marine isotope stage 3, Quaternary Res., 56, 357-365, 2001.

Cabioch, G., Thomassin, B. A., and Lecolle, J.: Age d'émersion des récifs frangeants holocènes autour de la "Grande Terre" de Nouvelle-Calédonie, nouvelle interprétation de la courbe des niveaux marins depuis 8000 ans BP, CR. Acad. Sci. II, 308, 419 425, 1989.

Cabioch, G., Montaggioni, L. F., and Faure, G.: Holocene initiation and development of New Caledonian fringing reefs, SW Pacific, Coral Reefs, 14, 131-140, 1995.

Cabioch, G., Récy, J., Jouannic, C., and Turpin, L.: Contrôle environnemental et néotectonique de 1'édification récifale en Nouvelle-Calédonie au tours du Quaternaire terminal, B. Soc. Geol. Fr., 167, 729-742, 1996.

Cabioch, G., Correge, T., Turpin, L., Castellaro, C., and Récy, J.: Development patterns of fringing and barrier reefs in New Caledonia (southwest Pacific), Oceanol. Acta, 22, 567-578, 1999.

Cabioch, G., Montaggioni, L., Thouveny, N., Frank, N., Sato, T., Chazottes, V., Dalamasso, H., Payri, C., Pichon, M., and Sémah, A.-M.: The chronology and structure of the western New Caledonian barrier reef tracts, Palaeogeogr. Palaeocl., 268, 91-105, 2008.

Calhoun, R. S. and Fletcher, C. H.: Late Holocene coastal plain stratigraphy and sea-level history at Hanalei, Kauai, Hawaiian Islands, Quaternary Res., 45, 47-58, 1996.

Camoin, G. F. and Webster, J. M.: Coral reef response to Quaternary sea-level and environmental changes: State of the science, Sedimentology, 62, 401-428, 2015.
Camoin, G. F., Ebren, P., Eisenhauer, A., Bard, E., and Faure, G.: A $300000-y r$ coral reef record of sea level changes, Mururoa atoll (Tuamotu archipelago, French Polynesia), Palaeogeogr. Palaeocl., 175, 325-341, 2001.

Carson, M. T.: Integrating fragments of a settlement pattern and cultural sequence in Wainiha Valley, Kaua'i, Hawaiian Islands, People and Culture in Oceania, 19, 83-105, 2003.

Carson, M. T.: Resolving the enigma of early coastal settlement in the Hawaiian Islands: The stratigraphic sequence of the Wainiha Beach site in Kaua'i, Geoarchaeology, 19, 99-118, 2004.

Chappell, J.: Astronomical theory of climatic change: Status and problem, Quaternary Res., 3, 221-236, 1973.

Chappell, J.: Geology of coral terraces, Huon Peninsula, New Guinea: A study of Quaternary tectonic movements and sea level changes, Geol. Soc. Am. Bull., 85, 553-570, 1974.

Chappell, J.: A revised sea level record for the last 300000 years from Papua New Guinea, Search, 4, 99-101, 1983.

Chappell, J.: Upper Quaternary sea levels, coral terraces, oxygen isotopes and deep-sea temperatures, J. Geogr., 103, 828-840, 1994.

Chappell, J. and Polach, H. A.: Some effects of partial recrystallization on ${ }^{14} \mathrm{C}$ dating late Pleistocene corals and molluscs, Quaternary Res., 2, 244-252, 1972.

Chappell, J. and Polach, H. A.: Post-glacial sea level rise from a coral record at Huon Peninsula, Papua New Guinea, Nature, 349 147-149, 1991.

Chappell, J. and Shackleton, N. J.: Oxygen isotopes and sea level, Nature, 324, 137-140, 1986.

Chappell, J. and Veeh, H. H.: Late Quaternary tectonic movements and sea-level changes at Timor and Atauro Island, Geol. Soc. Am. Bull., 89, 356-368, 1978.

Chappell, J., Ota, Y., and Berryman, K.: Late Quaternary coseismic uplift history of Huon Peninsula, Papua New Guinea, Quaternary Sci. Rev., 15, 7-22, 1996.

Chen, M.-C., Frohlich, C., Taylor, F. W., Burr, G., and van Ufford, A. Q.: Arc segmentation and seismicity in the Solomon Islands arc, SW Pacific, Tectonophysics, 507, 47-69, 2011.

Chikamori, M.: Development of coral reefs and human settlement: Archaeological research in the northern Cook Islands and Rarotonga, Bull. Indo-Pac. Pre. Hi., 15, 45-52, 1996.

Chikamori, M.: Archaeological Studies in the Cook Islands, Series 2, Occasional Papers of the Department of Archaeology and Ethnology, Keio University, Tokyo, Japan, 53 pp., 1998.

Chikamori, M.: Landscape changes in the coastal plains of fringing reef islands: Rarotonga in the Cook Islands, Shigaku, 70, 331350, 2001.

Chutcharavan, P. M. and Dutton, A.: A Global Compilation of Useries Dated Fossil Coral Sea-level Indicators for the Last Interglacial Period (MIS 5e), Earth Syst. Sci. Data Discuss. [preprint], https://doi.org/10.5194/essd-2020-381, in review, 2020.

Cloud Jr., P. E.: Superficial aspects of modern organic reefs, Sci. Mon., 79, 195-208, 1954.

Cloud Jr., P. E., Schmidt, R. G., and Burke, H. W.: Geology of Saipan, Mariana Islands, Part 1: General Geology, Professional Paper 280-A, U.S. Geological Survey, 126 pp., 1956.

Couch Jr., R. F., Fetzer, J. A., Goter, E. R., Ristvet, B. L., Tremba, E. L., Walter, D. R., and Wendland, V. P.: Drilling Operations on Eniwetok Atoll during Project EXPOE, AFWL-TR-75-216, Air Force Weapons Laboratory, 270 pp., 1975. 
Coudray, J.: Nouvelles données sur la nature et I'origine du complexe récifal côtier de la Nouvelle Calédonie, Quaternary Res., 1, 236-246, 1971.

Coudray, J.: Recherches sur le Néogène et le Quaternaire marins de la Nouvelle-Calédonie: contribution de l'étude sédimentologique à la connaissance de l'histoire géologique post-Eocène, Éditions de la Fondation Singer-Polignac, Paris, France, 276 pp., 1976.

Coudray, J. and Delibrias, G.: Variations du niveau marin au-dessus de l'actuel en Nouvelle-Calédonie depuis 6000 ans, CR. Acad. Sci. Série D-Sciences Naturelles, 375, 2623-2626, 1972.

Curray, J. R., Shepard, F. P., and Veeh, H. H.: Late Quaternary sea-level studies in Micronesia: CARMARSEL expedition, Geol. Soc. Am. Bull., 81, 1865-1880, 1970.

Cutler, K. B., Edwards, R. L., Taylor, F. W., Cheng, H., Adkins, J., Gallup, C. D., Cutler, P. M., Burr, G. S., and Bloom, A. L.: Rapid sea-level fall and deep-ocean temperature change since the last interglacial period, Earth Planet. Sc. Lett., 206, 253-271, 2003.

Daly, R. A.: A general sinking of sea-level in recent time, P. Natl. Acad. Sci. USA, 6, 246-250, 1920.

Dana, J. D.: Corals and Coral Islands, Dodd and Mead, New York, USA, 428 pp., 1872.

Darwin, C.: The structure and distribution of coral reefs: Being the first part of the geology of the voyage of the Beagle, under the command of Capt. Fitzroy, R. N. during the years 1832 to 1836 , Smith Elder and Co., London, UK, 1842.

David, T. W. E.: Narrative of the second and third expeditions, in: The atoll of Funafuti: borings into a coral reef and the results, being the report of the Coral Reef Committee of the Royal Society, edited by: Armstrong, H. E., Blanford, W. T., Bonney, T. G., Crookes, W., Darwin, F., Evans, J., Geikie, A., Hinde, G. J., Judd, J. W., Lankester, E. R., Lapworth, C., Murray, J., Sollas, W. J., Sorby, H. C., Teall, J. J. H., Wharton, W. J. L., Wolfe, B., Field, A. M., and Watts, W. W., The Royal Society of London, London, UK, 40-60, 1904.

David, T. W. E. and Sweet, G.: The geology of Funafuti, in: The atoll of Funafuti: borings into a coral reef and the results, being the report of the Coral Reef Committee of the Royal Society, edited by: Armstrong, H. E., Blanford, W. T., Bonney, T. G., Crookes, W., Darwin, F., Evans, J., Geikie, A., Hinde, G. J., Judd, J. W., Lankester, E. R., Lapworth, C., Murray, J., Sollas, W. J., Sorby, H. C., Teall, J. J. H., Wharton, W. J. L., Wolfe, B., Field, A. M., and Watts, W. W., The Royal Society of London, London, UK, 61-124, 1904.

Degaugue-Michalski, F.-M.: Croissance et évolution d'édifices récifaux du Pacifique occidental (Nouvelle-Calédonie, Chesterfield) à l'Holocène et au Pléistocène, $\mathrm{PhD}$ thesis, Université de Provence Aix-Marseille-I, France, 227 pp., 1993.

Dickinson, W. R.: Holocene sea-level record on Funafuti and potential impact of global warming on Central Pacific Atolls, Quaternary Res., 51, 124-132, 1999.

Dickinson, W. R.: Paleoshoreline record of relative Holocene sea levels on Pacific Islands, Earth-Sci. Rev., 55, 191-234, 2001.

Dickinson, W. R.: Impact of Mid-Holocene hydro-isostatic highstand in regional sea level on habitability of islands in Pacific Oceania, J. Coastal Res., 19, 489-502, 2003.

Dickinson, W. R.: Impacts of eustasy and hydro-isostasy on the evolution and landforms of Pacific atolls, Palaeogeogr. Palaeocl., 213, 251-269, 2004.
Dickinson, W. R., Burley, D. V., and Shutler Jr., R.: Impact of hydroisostatic Holocene sea-level change on the geologic context of island archaeological sites, Northern Ha'apai Group, Kingdom of Tonga, Geoarchaeology, 9, 85-111, 1994.

Dutton, A. and Lambeck, K.: Ice volume and sea level during the Last Interglacial, Science, 337, 216-219, 2012.

Easton, W. H. and Olson, E. A.: Radiocarbon profile of Hanauma Reef, Oahu, Hawaii, Geol. Soc. Am. Bull., 87, 711-719, 1976.

Easton, W. H., Ku, T. L., and Randall, R. H.: Recent reefs and shore lines of Guam, Micronesica, 14, 1-11, 1978.

Edwards, R. L., Chen, J. H., and Wasserburg, G. J.: ${ }^{238} \mathrm{U}-{ }^{234} \mathrm{U}-{ }^{230} \mathrm{Th}-{ }^{232} \mathrm{Th}$ systematics and the precise measurement of time over the past 500000 years, Earth Planet. Sc. Lett., 81, 175-192, 1987a.

Edwards, R. L., Chen, J. H., Ku, T.-L., and Wasserburg, G. J.: Precise timing of the last interglacial period from mass spectrometric determination of thorium-230 in corals, Science, 236, 15471553, $1987 \mathrm{~b}$.

Ellison, J. C.: Holocene sea level record of Tongatapu, Kingdom of Tonga, from pollen analysis of mangrove sediments, Master thesis, Simon Fraser University, Canada, 94 pp., 1988.

Ellison, J. C.: Paleo-lake and swamp stratigraphic records of Holocene vegetation and sea-level changes, Mangaia, Cook Islands, Pac. Sci., 48, 1-15, 1994.

Emery, K. O.: Marine geology of Guam, Professional Paper 403-B, U.S. Geological Survey, 76 pp., 1962.

Emery, K. O.: Marine geology of Guam, Professional Paper 403-B, U.S. Geological Survey, 76 pp., 1963.

Emery, K. O., Tracey Jr., J. I., and Ladd, H. S.: Geology of Bikini and nearby atolls, Professional Paper 260-A, U.S. Geological Survey, 265 pp., 1954.

Esat, T. M., McCulloch, M. T., Chappell, J., Pillans, B., and Omura, A.: Rapid fluctuations in sea level recorded at Huon Peninsula during the Penultimate Deglaciation, Science, 283, 197-201, 1999.

Fairbridge, R. W.: Eustatic charges in sea level, in: Physics and chemistry of the Earth, edited by: Ahrens, L. H., Press, F., Rankama, K., and Runcorn, S. K., Pergamon Press, New York, USA, 99-185, 1961.

Fletcher, C. H. and Jones, A. T.: Sea-level highstand recorded in Holocene shoreline deposits on Oahu, Hawaii, J. Sediment. Res., 66, 632-641, 1996.

Fletcher, C. H. and Richmond, B. M.: Climate change in the Federated States of Micronesia: food and water security, climate risk management, and adaptive strategies, report of findings 2010, University of Hawai'i Sea Grant College Program, USA, 32 pp., 2010.

Frank, N., Turpin, L., Cabioch, G., Blamart, D., Tressens-Fedou, M., Colin, C., and Jean-Baptiste, P.: Open system U-series ages of corals from a subsiding reef in New Caledonia: Implications for sea level changes, and subsidence rate, Earth Planet. Sc. Lett., 249, 274-289, 2006.

Fujimoto, K., Miyagi, T., Kikuchi, T., and Kawana, T.: Mangrove habitat formation and response to Holocene sea-level changes on Kosrae Island, Micronesia, Mangroves and Salt Marshes, 1, 4757, https://doi.org/10.1023/A:1025994128221, 1996.

Gaven, C. and Bourrouilh-Le Jan, F.: Géochronologie $\left({ }^{230} \mathrm{Th}-{ }^{234} \mathrm{U}-{ }^{238} \mathrm{U}\right)$ et sédimentologie des faciés récifaux 
pléstocénes à Maré, Archipel des Loyautés, SW Pacifique, Océanis, 7, 347-366, 1981.

Gischler, E., Hudson, J. H., Humblet, M., Braga, J. C., Eisenhauer, A., Isaack, A., Anselmetti, F. S., and Camoin, G. F.: Late Quaternary barrier and fringing reef development of Bora Bora (Society Islands, south Pacific): First subsurface data from the Darwintype barrier-reef system, Sedimentology, 63, 1522-1549, 2016.

Gischler, E., Hudson, J. H., Humblet, M., Braga, J. C., Schmitt, D., Isaack, A., Eisenhauer, A., and Camoin, G. F.: Holocene and Pleistocene fringing reef growth and the role of accommodation space and exposure to waves and currents (Bora Bora, Society Islands, French Polynesia), Sedimentology, 66, 305-328, 2019.

Goodwin, I. and Grossman, E. E.: Middle to late Holocene coastal evolution along the south coast of Upolu Island, Samoa, Mar. Geol., 202, 1-16, 2003.

Goodwin, I. D. and Harvey, N.: Subtropical sea-level history from coral microatolls in the Southern Cook Islands, since 300 AD, Mar. Geol., 253, 14-25, 2008.

Grant-Taylor, T. L. and Rafter, T. A.: New Zealand radiocarbon age measurements, New Zeal. J. Geol. Geop., 5, 331-359, 1962.

Gray, S. C., Hein, J. R., Hausmann, R., and Radtke, U.: Geochronology and subsurface stratigraphy of Pukapuka and Rakahanga atolls, Cook Islands: Late Quaternary reef growth and sea level history, Palaeogeogr. Palaeocl., 91, 377-394, 1992.

Green, R. C.: Lapita, in: The prehistory of Polynesia, edited by: Jennings, J. D., Australian National University, Canberra, Australia, 27-60, 1979.

Grigg, R. W.: Holocene coral reef accretion in Hawaii: a function of wave exposure and sea level history, Coral Reefs, 17, 263-272, 1998.

Gross, M. G., Milliman, J. D., Tracey, J. I., and Ladd, H. S.: Marine geology of Kure and Midway atolls, Hawaii: a preliminary report, Pac. Sci., 23, 17-25, 1969.

Grossman, E. E. and Fletcher, C. H.: Sea level higher than present 3500 years ago on the northern main Hawaiian Islands, Geology, 26, 363-366, 1998.

Grossman, E. E., Fletcher, C. H., and Richmond, B. M.: The Holocene sea-level highstand in the equatorial Pacific: analysis of the insular paleosea-level database, Coral Reefs, 17, 309-327, 1998.

Grover, J. C.: The Solomon Islands: geological exploration and research, 1953-1956, Memoir 2, Geological Survey of the British Solomon Islands, 150 pp., 1958.

Guilcher, A., Berthois, L., Doumenge, F., Michel, A., SaintRequier, A., and Arnold, R.: Les récifs et lagons coralliens de Mopelia et de Bora Bora (Îles de la Société), Mémoires ORSTOM, Paris, France, 107 pp., 1969.

Hallmann, N. and Camoin, G.: Database of Last Interglacial (MIS 5e) sea-level proxies on tropical Pacific islands [data set], Zenodo, https://doi.org/10.5281/zenodo.3991672, 2020.

Hallmann, N., Camoin, G., Eisenhauer, A., Botella, A., Milne, G. A., Vella, C., Samankassou, E., Pothin, V., Dussouillez, P., Fleury, J., and Fietzke, J.: Ice volume and climate changes from a 6000 year sea-level record in French Polynesia, Nat. Commun., 9, 285, https://doi.org/10.1038/s41467-017-02695-7, 2018.

Hallmann, N., Camoin, G., Eisenhauer, A., Samankassou, E., Vella, C., Botella, A., Milne, G. A., Pothin, V., Dussouillez, P., Fleury, J., Fietzke, J., and Goepfert, T.: Reef response to sealevel and environmental changes in the Central South Pacific over the past 6000 years, Glob. Planet. Change, 195, 103357 , https://doi.org/10.1016/j.gloplacha.2020.103357, 2020.

Hearty, P. J.: The Ka'ena Highstand of O'ahu, Hawai'i: further evidence of Antarctic ice collapse during the Middle Pleistocene, Pac. Sci., 56, 65-81, 2002.

Hearty, P. J., Hollin, J. T., Neumann, A. C., O’Leary, M. J., and McCulloch, M.: Global sea-level fluctuations during the Last Interglaciation (MIS 5e), Quaternary Sci. Rev., 26, 2090-2112, 2007.

Henry, R. W., Mercer, J. W., and Zbur, R. T.: Near surface geologic investigations at Eniwetok Atoll, in: Proceedings of the 2. International Symposium on Coral Reefs, Great Barrier Reef Committee, Brisbane, Australia, 22 June-2 July 1973, 615-626, 1974.

Henry, T. W. and Wardlaw, B. R.: Introduction: Enewetak Atoll and the PEACE Program, geological and geophysical investigations of Enewetak Atoll, Republic of the Marshall Islands, Professional Paper 1513-A, U.S. Geological Survey, 29 pp., 1990.

Henry, T. W., Wardlaw, B. R., Skipp, B., Major, R. P., and Tracey Jr., J. I.: Pacific Enewetak Crater Exploration (PEACE) Program, Enewetak Atoll, Republic of the Marshall Islands, Part 1: Drilling operations and descriptions of bore holes in vicinity of KOA and OAK craters, Open File Report 86419, U.S. Geological Survey, Denver, CO, USA, 583 pp., https://doi.org/10.3133/ofr86419, 1986.

Hibbert, F. D., Rohling, E. J., Dutton, A., Williams, F. H., Chutcharavan, P. M., Zhao, C., and Tamisiea, M. E.: Coral indicators of past sea-level change: a global repository of U-series dated benchmarks, Quaternary Sci. Rev., 145, 1-56, 2016.

Hibbert, F. D., Williams, F. H., Fallon, S. J., and Rohling, E. J.: A database of biological and geomorphological sea-level markers from the Last Glacial Maximum to present, Scientific Data, 5, 180088, https://doi.org/10.1038/sdata.2018.88, 2018.

Hinde, G. J.: Report on the materials from the borings at the Funafuti atoll, in: The atoll of Funafuti: borings into a coral reef and the results, being the report of the Coral Reef Committee of the Royal Society, edited by: Armstrong, H. E., Blanford, W. T., Bonney, T. G., Crookes, W., Darwin, F., Evans, J., Geikie, A., Hinde, G. J., Judd, J. W., Lankester, E. R., Lapworth, C., Murray, J., Sollas, W. J., Sorby, H. C., Teall, J. J. H., Wharton, W. J. L., Wolfe, B., Field, A. M., and Watts, W. W., The Royal Society of London, London, UK, 186-361, 1904.

Hongo, C. and Wirrmann, D.: Preliminary identification of key coral species from New Caledonia (Southwest Pacific Ocean), their significance to reef formation, and responses to environmental change, Isl. Arc, 24, 31-46, 2015.

Huang, D., Benzoni, F., Fukami, H., Knowlton, N., Smith, N. D., and Budd, A. F.: Taxonomic classification of the reef coral families Merulinidae, Montastraeidae, and Diploastraeidae (Cnidaria: Anthozoa: Scleractinia), Zool. J. Linn. Soc.-Lond., 171, 277355, 2014.

Jones, A. T.: Holocene coral reef on Kauai, Hawaii: Evidence for a sea-level highstand in the central Pacific, in: Quaternary coasts of the United States: marine and lacustrine systems, edited by: Fletcher III, C. H. and Wehmiller, J. F., SEPM Spec. P., 48, 267271, 1992.

Jones, A. T.: Late Holocene shoreline development in the Hawaiian Islands, J. Coastal Res., 14, 3-9, 1998.

Jouannic, C., Taylor, F. W., Bloom, A. L., and Bernat, M.: Late Quaternary uplift history from emerged reef terraces of Santo and 
Malekula islands, central New Hebrides island arc, UN ESCAP, CCOP/SOPAC Tech. Bull., 3, 91-108, 1980.

Jouannic, C., Taylor, F. W., and Bloom, A. L.: Sur la surrection et la déformation d'un arc jeune: l'arc des Nouvelles Hébrides, in: Contribution à l'étude géodynamique du Sud-Ouest Pacifique, Travaux et Documents de l'ORSTOM, Paris, France, 147, 223 246, 1982

Kaplin, P. A.: Relief, age and types of Oceanic islands, New Zeal. Geogr., 36, 3-12, 1981.

Kawana, T., Miyagi, T., Fujimoto, K., and Kikuchi, T.: LateHolocene sea-level changes and mangrove development in Kosrae Island, the Carolines, Micronesia, in: Rapid sea-level rise and mangrove habitat, edited by: Kikuchi, T., Gifu University Institute for Basin Ecosystems, Gifu, Japan, 7 pp., 1995.

Kayanne, H., Ishii, T., Matsumoto, E., and Yonekura, N.: Late Holocene sea-level change on Rota and Guam, Mariana Islands, and its constraint on geophysical predictions, Quaternary Res., 40, 189-200, 1993.

Kayanne, H., Yasukochi, T., Yamaguchi, T., Yamano, H., and Yoneda, M.: Rapid settlement of Majuro Atoll, central Pacific, following its emergence at 2000 years CalBP, Geophys. Res. Lett., 38, L20405, https://doi.org/10.1029/2011GL049163, 2011.

Kear, D. and Wood, B. L.: The geology and hydrology of Western Samoa, New Zealand Geological Survey Bulletin, New Zealand Department of Scientific and Industrial Research, Bulletin 63, Wellington, New Zealand, 92 pp., 1959.

Kennedy, D. M., Marsters, T. H., Woods, J. L. D., and Woodroffe, C. D.: Shore platform development on an uplifting limestone island over multiple sea-level cycles, Niue, South Pacific, Geomorphology, 141-142, 170-182, 2012.

Kirch, P. V.: The Lapitoid period in West Polynesia: excavations and survey on Niuatoputapu, Tonga, J. Field Archaeol., 5, 1-13, 1978.

Kirch, P. V. and Yen, D. E.: Tikopia: The prehistory and ecology of a Polynesian outlier, Bernice P. Bishop Museum Bulletin, Bishop Museum Press, Honolulu, Hawaii, USA, 396 pp., 1982.

Ku, T.-L., Kimmel, M. A., Easton, W. H., and O’Neil, T. J.: Eustatic sea level 120000 years ago on Oahu, Hawaii, Science, 183, 959962, 1974

Kuenen, P. H.: Geology of coral reefs: the Snellius Expedition in the Eastern Part of the Netherlands East Indies 1929-1930, geological results, Kemink en Zoon, Utrecht, The Netherlands, 125 pp., 1933.

Labeyrie, J., Lalou, C., and Delibrias, G.: Étude des transgressions marines sur l'atoll de Mururoa par la datation des différents niveaux de corail, Cahiers du Pacifique, 13, 59-68, 1969.

Ladd, H. S. and Schlanger, S. O.: Drilling operations on Eniwetok atoll: Bikini and nearby atolls, Marshall Islands, Professional Paper 260-Y, U.S. Geological Survey, 863-903, 1960.

Ladd, H. S., Tracey Jr., J. I., and Lill, G. G.: Drilling on Bikini Atoll, Marshall Islands, Science, 107, 51-55, 1948.

Ladd, H. S., Ingerson, E., Townsend, R. C., Russell, M., and Stephenson, K.: Drilling on Eniwetok Atoll, Marshall Islands, AAPG Bull., 37, 2257-2280, 1953.

Ladd, H. S., Tracey Jr., J. I., and Gross, M. G.: Drilling on Midway Atoll, Hawaii, Science, 156, 1088-1094, 1967.

Ladd, H. S., Tracey Jr., J. I., and Gross, M. G.: Deep drilling on Midway Atoll, Professional Paper 680-A, U.S. Geological Survey, 22 pp., 1970.
Lalou, C., Labeyrie, J., and Delibrias, G.: Datation des calcaires coralliens de l'atoll de Mururoa (archipel des Tuamotu) de l'époque actuelle jusqu'à -500000 ans, CR. Acad. Sci. Série D-Sciences Naturelles, 263, 1946-1949, 1966.

Launay, J. and Reìcy, J.: Variations relatives du niveau de la mer et neìotectonique en Nouvelle-Caleìdonie au PleìistoceÌne supeìrieur et aÌ l'OligoceÌne, Rev. Geogr. Phys. Geol., 14, 47-66, 1972.

Leach, F. and Ward, G. K.: Archaeology on Kapingamarangi Atoll, a Polynesian outlier in the Eastern Caroline Islands, Studies in Prehistoric Anthropology, University of Otago, New Zealand, 150 pp., 1981.

Lecolle, J. and Bernat, M.: Late Quaternary surrection history of Efate island, New Hebrides island arc (Vanuatu): Th/U dates from uplifted terraces $=$ Histoire de la surrection de l'île d'Efate, arc insulaire des Nouvelles-Hébrides (Vanuatu) au cours du Quaternaire récent: datations de terrasses soulevées par la méthode U/Th, in: Proceedings of The Fifth International Coral Reef Congress, Tahiti, French Polynesia, 27 May-1 June 1985, 179184,1985 .

Ludwig, K. R., Halley, R. B., Simmons, K. R., and Peterman, Z. E.: Strontium-isotope stratigraphy of Enewetak Atoll, Geology, 16, 173-177, 1988.

Mallick, D. I. J. and Greenbaum, D.: Geology of southern Santo, New Hebrides Geological Survey Regional Report, 84 pp., 1977.

Marshall, J. F. and Jacobson, G.: Holocene growth of a mid-Pacific atoll: Tarawa, Kiribati, Coral Reefs, 4, 11-17, 1985.

Marshall, J. F. and Launay, J.: Uplift rates of the Loyalty Islands as determined by ${ }^{230} \mathrm{Th} /{ }^{234} \mathrm{U}$ dating of raised coral terraces, Quaternary Res., 9, 186-192, 1978.

Matsumoto, E., Matsushima, Y., and Miyata, T.: Holocene sea-level studies of swampy coastal plains in Truk and Ponape, Micronesia, in: Sea-level changes and tectonics in the middle Pacific, report of the HIPAC Project in 1984 and 1985, edited by: Sugimura, Y., Kobe University Press, Kobe, Japan, 95-110, 1986.

Matsumoto, E., Matsushima, Y., Miyata, T., and Maeda, Y.: Holocene high sea-level stand on Kauai, Hawaii, in: Sea-level changes and tectonics in the middle Pacific, report of the HIPAC Project in 1986 and 1987, edited by: Yonekura, N., University of Tokyo, Japan, 91-99, 1988.

Matsushima, Y., Sugimura, A., Berryman, K., Ishii, T., Maeda, Y., Matsumoto, E., and Yonekura, N.: Research report of B-party: Holocene sea-level changes in Fiji and Western Samoa, in: Sealevel changes and tectonics in the middle Pacific, report of the HIPAC Project in 1981, 1982 and 1983, edited by: Sugimura, A., Kobe University Press, Kobe, Japan, 137-185, 1984.

Maurizot, P. and Lafoy, Y.: Notice explicative, Carte géol: NouvelleCalédonie (1/50000), feuille Maré, Îles Loyauté, Nouméa: Service des Mines et de l'Energie, Bureau de Recherches Géologiques et Minières, carte géologique par Maurizot et al. (2003), 138 pp., 2003.

Mayer, A. G.: Coral reefs of Tutuila, with reference to the MurrayAgassiz solution theory, P. Natl. Acad. Sci. USA, 3, 522-526, 1917.

Mayor, A. G.: Rose Atoll, American Samoa, P. Am. Philos. Soc., 60, 62-70, 1921.

Mayor, A. G.: Rose Atoll, American Samoa, papers from the Department of Marine Biology, Carnegie Institution of Washington Publication, 19, 73-91, 1924. 
McLean, R. F. and Hosking, P. L.: Geomorphology of reef islands and atoll motu in Tuvalu, S. Pac. J. Nat. Sci., 11, 167-189, 1991.

McLean, R. F. and Woodroffe, C. D.: Coral atolls, in: Coastal evolution: Late Quaternary shoreline morphodynamics, edited by: Carter, R. W. G. and Woodroffe, C. D., Cambridge University Press, Cambridge, UK, 267-302, 1994.

McMurtry, G. M., Campbell, J. F., Fryer, G. J., and Fietzke, J.: Uplift of Oahu, Hawaii, during the past 500000 years as recorded by elevated reef deposits, Geology, 38, 27-30, 2010.

McNutt, M. and Menard, H. W.: Lithospheric flexure and uplifted atolls, J. Geophys. Res., 83, 1206-1212, 1978.

Miklavič, B., Mylroie, J. E., Jenson, J. W., Randall, R. H., Banner, J. L., and Partin, J. W.: NSF Workshop: sea-level changes into the MIS 5: from observation to prediction, Palma de Mallorca, Spain, 10-14 April 2012.

Mitchell, A. H. G.: Geology of South Malekula: Port Vila, Vanuatu, New Hebrides Condominium Geological Survey Report, 41 pp., 1966.

Mitchell, A. H. G.: Raised reef-capped terraces and Plio-Pleistocene sea level changes, North Malekula, New Hebrides, J. Geol., 77, 56-67, 1969.

Mitchell, A. H. G.: Geology of Northern Malekula, New Hebrides Geological Survey Regional Report, 56 pp., 1971.

Miyata, T., Maeda, Y., Matsumoto, E., Matsushima, Y., Rodda, P., and Sugimura, A.: Emerged notches and microatolls on Vanua Levu, Fiji, in: Sea-level changes and tectonics in the middle Pacific, report of the HIPAC Project in 1986 and 1987, edited by: Yonekura, N., University of Tokyo, Tokyo, Japan, 67-76, 1988.

Miyata, T., Maeda, Y., Matsumoto, E., Matsushima, Y., Rodda, P., Sugimura, A., and Kayanne, H.: Evidence for a Holocene high sea-level stand, Vanua Levu, Fiji, Quaternary Res., 33, 352-359, 1990.

Montaggioni, L. F.: Makatea Island, Tuamotu Archipelago, in: Proceedings of The Fifth International Coral Reef Congress, Tahiti, French Polynesia, 27 May-1 June 1985, 103-158, 1985.

Montaggioni, L. F. and Camoin, G. F.: Geology of Makatea Island, Tuamotu Archipelago, French Polynesia, in: Geology and hydrogeology of carbonate islands, edited by: Vacher, H. L. and Quinn, T., Elsevier, Amsterdam, The Netherlands, 453-474, 1997.

Montaggioni, L. F. and Pirazzoli, P. A.: The significance of exposed coral conglomerates from French Polynesia (Pacific Ocean) as indicators of recent relative sea level changes, Coral Reefs, 3, 29-42, 1984.

Montaggioni, L. F., Richard, G., Bourrouilh-Le Jan, F., Gabrié, C., Humbert, L., Monteforte, M., Naim, O., Payri, C., and Salvat, B.: Geology and marine biology of Makatea, an uplifted atoll, Tuamotu Archipelago, Central Pacific Ocean, J. Coastal Res., 1, 165-171, 1985.

Montaggioni, L. F., Cabioch, G., Thouveny, N., Frank, N., Sato, T., and Sémah, A. M.: Revisiting the Quaternary development history of the western New Caledonian shelf system: from ramp to barrier reef, Mar. Geol., 280, 57-75, 2011.

Montaggioni, L. F., Salvat, B., Aubanel, A., Eisenhauer, A., and Martin-Garina, B.: The mode and timing of windward reef-island accretion in relation with Holocene sea-level change: a case study from Takapoto Atoll, French Polynesia, Geomorphology, 318, 320-335, 2018.

Montaggioni, L. F., Collin, A., James, D., Salvat, B., MartinGarin, B., Siu, G., Taiarui, M., and Chancerelle, Y.: Morphol- ogy of fore-reef slopes and terraces, Takapoto Atoll (Tuamotu Archipelago, French Polynesia, central Pacific): The tectonic, sea-level and coral-growth control, Mar. Geol., 417, 106027, https://doi.org/10.1016/j.margeo.2019.106027, 2019a.

Montaggioni, L. F., Salvat, B., Aubanel, A., Pons-Branchu, E., Martin-Garin, B., Dapoigny, A., and Goeldner-Gianella, L.: New insights into the Holocene development history of a Pacific, low-lying coral reef island: Takapoto Atoll, French Polynesia, Quaternary Sci. Rev., 223, 105947, https://doi.org/10.1016/j.quascirev.2019.105947, 2019b.

Moore, W. U.: Coral reefs, Nature, 40, 203-204, 1889.

Moriwaki, H., Chikamori, M., Okuno, M., and Nakamura, T.: Holocene changes in sea level and coastal environments on Rarotonga, Cook Islands, South Pacific Ocean, Holocene, 16, 839$848,2006$.

Mörner, N.-A. and Matlack-Klein, P.: New records of sea level changes in the Fiji Islands, Oceanogr. Fish. Open Access J., 5, 555666, https://doi.org/10.19080/OFOAJ.2017.05.555666, 2017.

Muhs, D. R. and Szabo, B. J.: New uranium-series ages of the Waimanalo Limestone, Oahu, Hawaii: implications for sea level during the last interglacial period, Mar. Geol., 118, 315-326, 1994.

Muhs, D. R., Simmons, K. R., and Steinke, B.: Timing and warmth of the Last Interglacial period: new U-series evidence from Hawaii and Bermuda and a new fossil compilation for North America, Quaternary Sci. Rev., 21, 1355-1383, 2002.

Muhs, D. R., Schweig, E. S., and Simmons, K. R.: Late Quaternary sea-level history of Saipan, Commonwealth of the Northern Mariana Islands, USA: A test of tectonic uplift and glacial isostatic adjustment models, Geol. Soc. Am. Bull., 132, 863-883, 2020.

Neall, V. E. and Trewick, S. A.: The age and origin of the Pacific islands: a geological overview, Philos. T. Roy. Soc. B, 363, 3293 3308, 2008.

Neef, G. and McCulloch, M. T.: Pliocene-Quaternary history of Futuna Island, south Vanuatu, southwest Pacific, Aust. J. Earth Sci., 48, 805-814, 2001.

Neef, G. and Veeh, H. H.: Uranium series ages and late Quaternary uplift in the New Hebrides, Nature, 269, 682-683, 1977.

Neef, G., Zhao, J. X., Collerson, K. D., and Zhang, F. S.: Late Quaternary uplift and subsidence of the west coast of Tanna, south Vanuatu, southwest Pacific: U-Th ages of raised coral reefs in the Median Sedimentary Basin, Aust. J. Earth Sci., 50, 39-48, 2003.

Newell, N. D. and Bloom, A. L.: The reef flat and "two-meter eustatic terrace" of some Pacific atolls, Geol. Soc. Am. Bull., 81, 1881-1894, 1970.

Nunn, P. D.: Studies in the tectonics and structure of southern Fiji, Working Paper 10, School of Social and Economic Development, University of the South Pacific, Suva, Fiji, 54 pp., 1988.

Nunn, P. D.: Coastal processes and landforms of Fiji: their bearing on Holocene sea-level changes in the south and west Pacific, J. Coastal Res., 6, 279-310, 1990a.

Nunn, P. D.: Coastal geomorphology of Beca and Yanuca Islands, South Pacific Ocean, and its significance for the tectonic history of the Vatulele-Beqa Ridge, Pac. Sci., 44, 348-365, 1990 b.

Nunn, P. D.: Sea-level changes during the last 6000 years in Fiji, Tonga and Western Samoa: implications for future coastline development, in: Workshop on coastal processes in the South Pa- 
cific Island Nations, Lae, Papua New Guinea, 1-8 October 1987, 79-90, 1991.

Nunn, P. D.: Oceanic islands, Blackwell, Oxford, UK, 413 pp., 1994.

Nunn, P. D.: Holocene sea-level changes in the South and West Pacific, J. Coastal Res., 17, 311-319, 1995a.

Nunn, P. D.: Holocene tectonic histories for five islands in the southcentral Lau Group, South Pacific, Holocene, 5, 160-171, 1995b.

Nunn, P. D.: Significance of emerged Holocene corals around Ovalau and Moturiki islands, Fiji, southwest Pacific, Mar. Geol., 163, 345-351, 2000.

Nunn, P. D.: Climate, environment and society in the Pacific during the last millennium, in: Developments in Earth and Environmental Sciences, Elsevier, 302 pp., 2007.

Nunn, P. D. and Britton, J. M. R.: The long-term evolution of Niue Island, in: Niue Island: geographic perspectives on the rock of Polynesia, edited by: Terry, J. P. and Murray, W. E., Insula, 3173, 2004.

Nunn, P. D and Finau, F. T.: Holocene emergence history of Tongatapu island, South Pacific, Z. Geomorphol., 39, 69-95, 1995.

Nunn, P. D. and Omura, A.: Penultimate Interglacial emerged reef around Kadavu Island, Southwest Pacific: implications for late Quaternary island-arc tectonics and sea-level history, New Zeal. J. Geol. Geop., 42, 219-227, 1999.

Nunn, P. D. and Omura, A.: Quaternary shorelines of Kaibu Island, southwest Pacific Ocean: implications for Last Interglacial sealevel history and uplift of the Lau-Colville Ridge, Quat. Australasia, 21, 33-38, 2003.

Nunn, P. D. and Peltier, W. R.: Far-field test of the ICE-4G model of global isostatic response to deglaciation using empirical and theoretical Holocene sea-level reconstructions for the Fiji Islands, southwestern Pacific, Quaternary Res., 55, 203-214, 2001.

Nunn, P. D., Matararaba, S., and Ramos, J.: Investigations of anthropogenic sediments in Qaranilaca, Vanuabalavu Island, Fiji, Archaeol. New Zeal., 43, 73-79, 2000.

Nunn, P. D., Ollier, C., Hope, G., Rodda, P., Omura, A., and Peltier, W. R.: Late Quaternary sea-level and tectonic changes in northeast Fiji, Mar. Geol., 187, 299-311, 2002.

Nunn, P. D., Hunter-Anderson, R., Carson, M. T., Thomas, F., Ulm, S., and Rowland, M. J.: Times of plenty, times of less: Lastmillennium societal disruption in the Pacific Basin, Hum. Ecol., 35, 385-401, 2007.

Ohde, S., Greaves, M., Masuzawa, T., Buckley, H. A., VanWoesik, R., Wilson, P. A., Pirazzoli, P. A., and Elderfield, H.: The chronology of Funafuti atoll: revisiting an old friend, P. Roy. Soc. A-Math. Phy., 458, 2289-2306, 2002.

Omura, A., Chappell, J., Bloom, A. L., Pillans, B. J., McCulloch, M., Esat, T., Sasaki, K., and Kawada, Y.: Alpha-spectrometric ${ }^{230} \mathrm{Th} /{ }^{234} \mathrm{U}$ dating of Pleistocene corals, in: Study on Coral Reef Terraces of the Huon Peninsula, Papua New Guinea, edited by: Ota, Y., Department of Geography, Senshu University, Kawasaki, Japan, 95-110, 1994.

Ota, Y., Chappell, J., Kelley, R., Yonekura, N., Matsumoto, E., Nishimura, T., and Head, J.: Holocene coral reef terraces and coseismic uplift of Huon Peninsula, Papua New Guinea, Quaternary Res., 40, 177-188, 1993.

Paulay, G.: Effects of glacio-eustatic sea level fluctuations and local tectonics on the marine faunas of oceanic islands, $\mathrm{PhD}$ thesis, University of Washington, Seattle, USA, 287 pp., 1988.
Paulay, G. and McEdward, L. R.: A simulation model of island reef morphology: the effects of sea level fluctuations, growth, subsidence and erosion, Coral Reefs, 9, 51-62, 1990.

Paulay, G. and Spencer, T.: Niue Island: geologic and faunatic history of a Pliocene atoll, Pac. Sci. Assoc. Infor. Bull., 44, 21-23, 1992.

Pirazzoli, P. A.: A reconnaissance and geomorphological survey of Temoe atoll, Gambier Islands (South Pacific), J. Coastal Res., 3, 307-323, 1987.

Pirazzoli, P. A. and Montaggioni, L. F.: Late Holocene sea level changes in the northwest Tuamotu Islands, French Polynesia, Quaternary Res., 25, 350-368, 1986.

Pirazzoli, P. A. and Montaggioni, L. F.: Les Îles Gambier et l'atoll de Temoe (Polynésie française): anciennes lignes de rivage et comportement geodynamique, Géodynamique, 2, 13-28, 1987.

Pirazzoli, P. A. and Montaggioni, L. F.: Holocene sea-level changes in French Polynesia, Palaeogeogr. Palaeocl., 68, 153-175, 1988.

Pirazzoli, P. A., Montaggioni, L. F., Delibrias, G., Faure, G., and Salvat, B.: Late Holocene sea-level changes in the Society Islands and in the northwest Tuamotu atolls, in: Proceedings of The Fifth International Coral Reef Congress, Tahiti, French Polynesia, 27 May-1 June 1985, 131-136, 1985a.

Pirazzoli, P. A., Brousse, R., Delibrias, G., Montaggioni, L. F., Sachet, M. H., Salvat, B., and Sinoto, Y. H.: Îles Sous le Vent: Maupiti, Tupai, Bora Bora, Huahine, Archipel de la Société, Les récifs coralliens de Polynésie Française: connaissance des récifs et guides d'excursion, in: Proceedings of The Fifth International Coral Reef Congress, Tahiti, French Polynesia, 27 May1 June 1985, 19-72, 1985b.

Pirazzoli, P. A., Montaggioni, L. F., Vergnaud-Grazzini, C., and Saliege, J. F.: Late Holocene sea levels and coral reef development in Vahitahi atoll, eastern Tuamotu Islands, Pacific Ocean, Mar. Geol., 76, 105-115, 1987.

Pirazzoli, P. A., Koba, M., Montaggioni, L. F., and Person, A.: Anaa (Tuamotu Islands, central Pacific): an incipient rising atoll?, Mar. Geol., 82, 261-269, 1988a.

Pirazzoli, P. A., Montaggioni, L. F., Salvat, B., and Faure, G.: Late Holocene sea level indicators from twelve atolls in the central and eastern Tuamotus (Pacific Ocean), Coral Reefs, 7, 57-68, 1988b.

Potratz, H. A., Barnes, J. W., and Lang, E. J.: A radiochemical procedure for thorium and its application to the determination of ionium in coral limestone, U.S. Atomic Energy Commission, Los Alamos Scientific Laboratory, University of California, California, USA, 13 pp., 1955.

Quinn, T. M.: The history of post-Miocene sea level change: inferences from stratigraphic modeling of Enewetak Atoll, J. Geophys. Res., 96, 6713-6725, 1991.

Quinn, T. M. and Matthews, R. K.: Post-Miocene diagenetic and eustatic history of Enewetak Atoll: model and data comparison, Geology, 18, 942-945, 1990.

Randall, R. H. and Siegrist, H. G.: Geomorphology of the fringing reefs of northern Guam in response to Holocene sea level changes, in: Proceedings of the 6th International Coral Reef Symposium, edited by: Choat, J. H., Barnes, D., Borowitzka, M. A., Coll, J. C., Davies, P. J., Flood, P., Hatcher, B. G., Hopley, D., Hutchings, P. A., Kinsey, D., Orme, G. R., Pichon, M., Sale, P. F., Sammarco, P., Wallace, C. C., Wilkinson, C., Wolomski, E., 
and Bellwood, O., Townsville, Australia, 473-477, 8-12 August 1988.

Randall, R. H. and Siegrist, H. G.: The legacy of Tarague Embayment and its inhabitants, Anderson AFB, Guam, Geology, beaches, and coral reefs, prepared for Andersen Air Force Base, International Archaeology, Inc., Honolulu, Hawaii, USA, 462 pp., 1996.

Rashid, R., Eisenhauer, A., Stocchi, P., Liebetrau, V., Fietzke, J., Rüggeberg, A., and Dullo, W.-C.: Constraining mid to late Holocene relative sea level change in the southern equatorial Pacific Ocean relative to the Society Islands, French Polynesia, Geochem. Geophy. Geosy., 15, 1-15, https://doi.org/10.1002/2014GC005272, 2014.

Riker-Coleman, K. E., Gallup, C. D., Wallace, L. M., Webster, J. M., Cheng, H., and Edwards, R. L.: Evidence of Holocene uplift in east New Britain, Papua New Guinea, Geophys. Res. Lett., 33, L18612, https://doi.org/10.1029/2006GL026596, 2006.

Robinson, G. P.: The geology of north Santo, New Hebrides Geological Survey Regional Report, 77 pp., 1969.

Rodda, P.: Late Quaternary geology of Fiji, in: Sea-level changes and tectonics in the middle Pacific, report of the HIPAC Project in 1984 and 1985, edited by: Sugimura, Y., Kobe University Press, Kobe, Japan, 15-24, 1986.

Rodda, P.: Visit to Western Samoa with the HIPAC Team, in: Sealevel changes and tectonics in the middle Pacific, report of the HIPAC Project in 1986 and 1987, edited by: Yonekura, N., University of Tokyo, Tokyo, Japan, 85-90, 1988.

Rovere, A., Raymo, M. E., Vacchi, M., Lorscheid, T., Stocchi, P., Gomez-Pujol, L., Harris, D. L., Casella, E., O'Leary, M. J., and Hearty, P. J.: The analysis of Last Interglacial (MIS 5e) relative sea-level indicators: reconstructing sea-level in a warmer world, Earth-Sci. Rev., 159, 404-427, 2016.

Rovere, A., Deirdre, R., Murray-Wallace, C., Simms, A., Vacchi, M., Dutton, A., Lorscheid, T., Chutcharavan, P., Brill, D., Bartz, M., Jankowski, N., Mueller, D., Cohen, K., and Gowan, E.: Descriptions of database fields for the World Atlas of Last Interglacial Shorelines (WALIS) [data set], Zenodo, https://doi.org/10.5281/zenodo.3961544, 2020.

Roy, P.: Coastal and nearshore geology of Savusavu Bay, Vanua Levu, Fiji, CCOP/SOPAC, Suva, Fiji, Tech. Rep., 33 pp., 1988.

Rubin, K. H., Sherman, C. E., and Fletcher III, C. H.: Ages of emerged coral deposits in Kapihaa Gulch, Lana'i, Hawaiian Islands and speculation about their environment of deposition, EOS T. Am. Geophys. Un., 76, p. 307, 1995.

Rubin, K. H., Fletcher III, C. H., and Sherman, C.: Fossiliferous Lana'i deposits formed by multiple events rather than a single giant tsunami, Nature, 408, 675-681, 2000.

Schlanger, S. O.: Subsurface Geology of Eniwetok Atoll, Professional Paper 260-BB, U.S. Geological Survey, 991-1048, 1963.

Schofield, J. C.: Notes on late Quaternary sea levels, Fiji and Rarotonga, New Zeal. J. Geol. Geop., 13, 199-206, 1910.

Schofield, J. C.: The geology and hydrology of Niue Island, South Pacific, New Zeal. Geol. Surv. Bull., 27 pp., 1959.

Schofield, J. C.: Notes on late Quaternary sea levels, Fiji and Rarotonga, New Zeal. J. Geol. Geop., 14, 240-241, 1970.

Schofield, J. C.: Late Holocene sea level, Gilbert and Ellice Islands, west central Pacific Ocean, New Zeal. J. Geol. Geop., 20, 503529, 1977a.
Schofield, J. C.: Effect of Late Holocene sea-level fall on atoll development, New Zeal. J. Geol. Geop., 20, 531-536, 1977 b.

Scoffin, T. P., Stoddart, D. R., Tudhope, A. W., and Woodroffe, C. D.: Exposed limestones of Suwarrow Atoll, in: Proceedings of The Fifth International Coral Reef Congress, Tahiti, French Polynesia, 27 May-1 June 1985, 137-140, 1985.

Shepard, F. P.: Thirty-five thousand years of sea level, in: Essays in marine geology in honor of Emery, K. O., edited by: Clements, T., University of Southern California Press, Los Angeles, USA, 1-10, 1963.

Shepard, F. P.: The evolution of a moderate energy coast in Holocene time, Pacific Harbour, Viti Levu, Fiji, New Zeal. J. Geol. Geop., 33, 547-556, 1990.

Shepard, F. P., Curray, J. R., Newman, W. A., Bloom, A. L., Newell, N. D., Tracey Jr., J. I., and Veeh, H. H.: Holocene changes in sea level: evidence in Micronesia, Science, 157, 542-544, 1967.

Sherman, C. E., Glenn, C. R., Jones, A. T., Burnett, W. C., and Schwarcz, H. P.: New evidence for two highstands of the sea during the Last Interglacial, oxygen isotope stage 5e, Geology, 21, 1079-1082, 1993.

Sherman, C. E., Fletcher, C. H., and Rubin, K. H.: Marine and meteoric diagenesis of Pleistocene carbonates from a nearshore submarine terrace, Oahu, Hawaii, J. Sediment. Res., 69, 1083-1097, 1999.

Sherman, C. E., Fletcher, C. H., Rubin, K. H., Simmons, K. R., and Adey, W. H.: Sea-level and reef accretion history of Marine Oxygen Isotope Stage 7 and late Stage 5 based on age and facies of submerged late Pleistocene reefs, Oahu, Hawaii, Quaternary Res., 81, 138-150, 2014.

Spencer, T. and Paulay, G.: Geomorphology, uplift and sea level history of Niue Island, southwest Polynesia, in: Proceedings of the 7th International Coral Reef Symposium, Guam, Micronesia, USA, 22-27 June 1992, p. 1227, 1994.

Spencer, T., Stoddart, D. R., and Woodroffe, C. D.: Island uplift and lithospheric flexure, observations and cautions from the South Pacific, Z. Geomorphol., 63, 87-102, 1987.

Spencer, T., Stoddart, D. R., Woodroffe, C. D., and Harmon, R. S.: Lithospheric flexure and raised reef limestones, S. CooksAustral Islands, in: Proceedings of the 6th International Coral Reef Congress, Townsville City, Australia, 8-12 August 1988, 485-489, 1988.

Spencer, T., Stoddart, D. R., and McLean, R. F.: Coral reefs, in: The history of the study of landforms volume 4: Quaternary and recent processes and forms (1890-1965) and the mid-century revolutions, edited by: Burt, T. P., Chorley, R. J., Brunsden, D., Cox, N. J., and Goudie, A. S., The Geological Society, London, UK, 863-922, 2008.

Spenneman, D. H. R.: A Holocene sea-level history for Tongatapu, Kingdom of Tonga, in: Coastal and environmental Geoscience studies of the Southwest Pacific Islands, compiled by: Sherwood, A. M., edited by: Howorth, R. and Rodda, P., SOPAC Techn. Bull. 9, Suva, Fiji, 115-149, 275 pp., ISBN: 982-207004-7, 1997.

Spriggs, M.: The Island Melanesians, Wiley-Blackwell, Oxford, UK, 320 pp., 1997.

Stearns, H. T.: Pleistocene shorelines on the islands of Oahu and Maui, Hawaii, Geol. Soc. Am. Bull., 46, 1927-1956, 1935a.

Stearns, H. T.: Shore benches on the island of Oahu, Hawaii, Geol. Soc. Am. Bull., 46, 1467-1482, 1935 b. 
Stearns, H. T.: Geology and ground-water resources of the island of Oahu, Hawaii, Hawaii Div. Hydrogr. Bull., 479 pp., 1935c.

Stearns, H. T.: Geologic history of Guam, Geol. Soc. Am. Bull., 52, p. $1948,1940$.

Stearns, H. T.: Shore benches on North Pacific Islands, Geol. Soc. Am. Bull., 52, 773-780, 1941.

Stearns, H. T.: Geology of the Samoan Islands, Geol. Soc. Am. Bull., 55, 1279-1332, 1944.

Stearns, H. T.: Eustatic shorelines in the Pacific, Geol. Soc. Am. Bull., 56, 1071-1078, 1945.

Stearns, H. T.: Submerged shorelines and shelves in the Hawaiian Islands and a revision of some of the eustatic emerged shorelines, Geol. Soc. Am. Bull., 85, 795-804, 1974.

Stearns, H. T. and Chamberlain, T. K.: Deep cores of Oahu, Hawaii and their bearing on the geologic history of the Central Pacific Basin, Pac. Sci., 11, 153-165, 1967.

Stein, M., Wasserburg, G. J., Aharon, P., Chen, J. H., Zhu, Z. R., Bloom, A., and Chappell, J.: TIMS U-series dating and stable isotopes of the last interglacial event in Papua New Guinea, Geochim. Cosmochim. Ac., 57, 2541-2554, 1993.

Stice, G. D. and McCoy, F. W.: The geology of the Manu'a Islands, Samoa, Pac. Sci., 22, 427-457, 1968.

Stoddart, D. R.: Marine biology, geomorphology of the Solomon Islands coral reefs, Philos. T. Roy. Soc. B, 255, 355-382, 1969.

Stoddart, D. R.: Reef islands of Rarotonga, Atoll Research Bulletin, 160, 1-7, 1972.

Stoddart, D. R.: Almost-atoll of Aitutaki: geomorphology of reefs and islands, Atoll Research Bulletin, 190, 31-57, 1975.

Stoddart, D. R., Spencer, T., and Scoffin, T. P.: Reef growth and karst erosion on Mangaia, Cook Islands: a re-interpretation in geomorphology of changing coastlines, Z. Geomorphol., 57, 121140, 1985.

Stoddart, D. R., Woodroffe, C. D., and Spencer, T.: Mauke, Mitiaro and Atiu: geomorphology of Makatea Islands in the southern Cooks, Atoll Research Bulletin, 341, 1-65, 1990.

Sugimura, A., Maeda, Y., Matsushima, Y., and Rodda, P.: Further report on sea-level investigation in Western Samoa, in: Sea-level changes and tectonics in the middle Pacific, report of the HIPAC Project in 1986 and 1987, edited by: Yonekura, N., University of Tokyo, Tokyo, Japan, 77-84, 1988a.

Sugimura, A., Maeda, Y., Matsushima, Y., Rodda, P., and Matsumoto, E.: Lobau Lowland, Viti Levu, Fiji, in: Sea-level changes and tectonics in the middle Pacific, report of the HIPAC Project in 1986 and 1987, edited by: Yonekura, N., University of Tokyo, Tokyo, Japan, 59-65, 1988b.

Szabo, B. J., Tracey, J., and Goter, E.: Ages of subsurface stratigraphic intervals in the Quaternary of Enewetak Atoll, Marshall Islands, Quaternary Res., 23, 54-61, 1985.

Szabo, B. J., Ludwig, K. R., Muhs, D. R., and Simmons, K. R.: Thorium-230 ages of corals and the duration of the last interglacial sea-level highstand on O'ahu, Hawaii, Science, 266, 9396, 1994.

Tayama, R.: Coral reefs in the South Seas, Bull. Hydrogr., 11, 1292, 1952.

Taylor, F. W.: Quaternary tectonic and sea-level history, Tonga and Fiji, Southwest Pacific, PhD thesis, Cornell University, Ithaca, New York, USA, 355 pp., 1978.
Taylor, F. W. and Bloom, A. L.: Coral Reefs in tectonic blocks, Tonga Island Arc, in: Proceedings of the 3rd International Coral Reef Symposium, Miami, USA, 275-281, 1977.

Taylor, F. W., Isacks, B. L., Jouannic, C., Bloom, A. L., and Dubois, J.: Coseismic and Quaternary vertical tectonic movements, Santo and Malekula Islands, New Hebrides Island Arc, J. Geophys. Res., 85, 5367-5381, 1980.

Taylor, F. W., Jouannic, C., and Bloom, A. L.: Quaternary uplift of the Torres Islands, Northern New Hebrides frontal arc: comparison with Santo and Malekula Islands, central New Hebrides frontal arc, Geology, 93, 419-438, 1985.

Taylor, F. W., Frohlich, C., Lecolle, J., and Strecker, M.: Analysis of partially emerged corals and reef terraces in the central Vanuatu arc: comparison of contemporary coseismic and nonseismic with Quaternary vertical movements, J. Geophys. Res., 92, 4905-4933, 1987.

Taylor, F. W., Mann, P., Bevis, M. G., Edwards, R. L., Cheng, H., Cutler, K. B., Gray, S. C., Burr, G. S., Beck, J. W., Phillips, D. A., Cabioch, G., and Recy, J.: Rapid forearc uplift and subsidence caused by impinging bathymetric features: examples from the New Hebrides and Solomon arcs, Tectonics, 24, TC6005, https://doi.org/10.1029/2004TC001650, 2005.

Terry, P. and Nunn, P. D.: Interpreting features of carbonate geomorphology on Niue Island, a raised coral atoll, Z. Geomorphol., 131, 43-57, 2003.

Thirumalai, K., Taylor, F. W., Shen, C.-C., Lavier, L. L., Frohlich, C., Wallace, L. M., Wu, C.-C., Sun, H., and Papabatu, A. K.: Variable Holocene deformation above a shallow subduction zone extremely close to the trench, Nat. Commun., 6, 7607, https://doi.org/10.1038/ncomms8607, 2015.

Thomas, F. R., Nunn, P. D., Osborne, T., Kumar, R., Areki, F., Matararaba, S., Steadman, D., and Hope, G.: Recent archaeological findings at Qaranilaca Cave, Vanuabalavu Island, Fiji, Archaeol. Ocean., 39, 42-49, 2004.

Thompson, G. M., Malpas, J., and Smith, I. E. M.: Volcanic geology of Rarotonga, southern Pacific Ocean, New Zeal. J. Geol. Geop., 41, 95-104, 1998.

Thompson, W. G., Curran, H. A., Wilson, M. A., and White, B.: Sea-level oscillations during the last interglacial highstand recorded by Bahamas corals, Nat. Geosci., 4, 684-687, 2011.

Thurber, D. L., Broecker, W. S., Blanchard, R. L., and Potratz, H. A.: Uranium-series ages of Pacific atoll coral, Science, 149, 55$58,1965$.

Tracey, J. I.: Recent reef features in the Caroline and Marshall Islands, Professional Paper 600-A, U.S. Geological Survey, 80 pp., 1968.

Tracey, J. I.: Holocene emergent reefs in the central Pacific, in: 2nd Conf. Am. Quat. Assoc., 2-5 December 1972, Miami, FL, USA, 51-52, 1972.

Tracey, J. I. and Ladd, H. S.: Quaternary history of Eniwetok and Bikini atolls, Marshall Islands, in: Proceedings of the 2nd International Coral Reef Symposium, Great Barrier Reef Province, Queensland, Australia, 22 June-2 July 1973, 537-550, 1974.

Tracey, J. I., Stensland, C. H., Doan, D. B., May, H. G., Schlanger, S. O., Stark, J. T., Blumenstock, D. I., Emery, K. O., and Fosberg, F. R.: Military geology of Guam, Mariana Islands, part I: Description of terrain and environment, part II: Engineering aspects of geology and soils, U.S. Army, Chief of Engineers, Washington D.C., USA, 282 pp., 1959. 
Tracey, J. I., Schlanger, S. O., Stark, J. T., Doan, D. B., and May, H. G.: General geology of Guam: geology and hydrology of Guam, Mariana Islands, Professional Paper 403-A, U.S. Geological Survey, Washington, D.C., USA, 104 pp., 1964.

Trichet, J., Repellin, P., and Oustriere, P.: Stratigraphy and subsidence of the Mururoa Atoll (French Polynesia), Mar. Geol., 56, 241-257, 1984.

Veeh, H. H.: $\mathrm{Th}^{230} / \mathrm{U}^{238}$ and $\mathrm{U}^{234} / \mathrm{U}^{238}$ ages of elevated Pleistocene coral reefs and their geological implications, $\mathrm{PhD}$ thesis, University of California, San Diego, USA, 182 pp., 1965.

Veeh, H. H.: $\mathrm{Th}^{230} / \mathrm{U}^{238}$ and $\mathrm{U}^{234} / \mathrm{U}^{238}$ ages of Pleistocene high sea level stand, J. Geophys. Res., 71, 3379-3386, 1966.

Veeh, H. H. and Chappell, J.: Astronomical theory of climate change: support from New Guinea, Science, 167, 862-865, 1970.

Wallace, C. C.: Staghorn corals of the world: a revision of the coral genus Acropora (Scleractinia; Astrocoeniina; Acroporidae) worldwide, with emphasis on morphology, phylogeny and biogeography, CSIRO Publishing, 422 pp., 1999.

Wardlaw, B. R. and Quinn, T. M.: The record of Pliocene sea-level change at Enewetak Atoll, Quaternary Sci. Rev., 10, 247-258, 1991.

Weary, D. J. and Burton, W. C.: Preliminary Geologic Map of the Island of Saipan, Commonwealth of the Northern Mariana Islands, Open-File Report 2011-1234, U.S. Geological Survey, 2011.

Webster, J. M., Clague, D. A., and Braga, J. C.: Support for the giant wave hypothesis: evidence from submerged terraces off Lanai, Hawaii, Int. J. Earth Sci., 96, 517-524, 2007.

Wells, J. W.: Fossil corals from Midway Atoll, Professional Paper 680-G, U.S. Geological Survey, 19 pp., 1982.

Wentworth, C. K. and Hoffmeister, J. E.: Geology of Ulupau Head, Oahu, Geol. Soc. Am. Bull., 50, 1553-1572, 1939.

Wheeler, C. W.: Stratigraphy, petrology, and geochemistry of a midoceanic carbonate platform: Niue Island, South Pacific, PhD thesis, Louisiana State University Historical Dissertations and Theses, Louisiana, USA, 461 pp., 2000.

Wiens, H. J.: Atoll development and ecology, Yale University Press, New Haven, USA, 532 pp., 1962.
Wirrmann, D., Sémah, A.-M., Debenay, J., and Chacornac-Rault, M.: Mid- to Late Holocene environmental and climatic changes in New Caledonia, Southwest tropical Pacific, inferred from the littoral plain Gouro-Déva, Quaternary Res., 76, 229-242, 2011.

Woodroffe, S. A. and Horton, B. P.: Holocene sea-level changes in the Indo-Pacific, J. Asian Earth Sci., 25, 29-43, 2005.

Woodroffe, C. D. and McLean, R. F.: Pleistocene morphology and Holocene emergence of Christmas (Kiritimati) Island, Pacific Ocean, Coral Reefs, 17, 235-248, 1998.

Woodroffe, C. D. and Morrison, R. J.: Reef-island accretion and soil development on Makin, Kiribati, central Pacific, Catena, 44, 245-261, 2001.

Woodroffe, C. D., Stoddart, D. R., Spencer, T., Scoffin, T. P., and Tudhope, A. W.: Holocene emergence in the Cook Islands, South Pacific, Coral Reefs, 9, 31-39, 1990.

Woodroffe, C. D., Short, S. A., Stoddart, D. R., Spencer, T., and Harmon, R. S.: Stratigraphy and chronology of late pleistocene reefs in the Southern Cook Islands, south Pacific, Quaternary Res., 35, 246-263, 1991.

Woodroffe, C. D., McGregor, H. V., Lambeck, K., Smithers, S. G., and Fink, D.: Mid-Pacific microatolls record sea-level stability over the past $5000 \mathrm{yr}$, Geology, 40, 951-954, 2012.

Yamano, H., Kayanne, H., Yamaguchi, T., Inoue, T., Mochida, Y., and Baba, S.: Revisiting late Holocene sea-level change from the Gilbert Islands, Kiribati, west-central Pacific Ocean, Quaternary Res., 88, 400-408, 2017.

Yonekura, N.: Late Quaternary vertical crustal movements in and around the Pacific as deduced from former shoreline data, in: Geodynamics of the western Pacific-Indonesian region, edited by: Hilde, T. W. and Uyeda, S., Geodynamics Series, American Geophysical Union, USA, 41-50, 1983.

Yonekura, N.: Geomorphic development of modern coral reefs and Holocene sea-level changes in the middle Pacific, J. Geogr., 103 , 841-852, 1994.

Yonekura, N., Ishii, T., Saito, Y., Maeda, Y., Matsushima, Y., Matsumoto, E., and Kayanne, H.: Holocene fringing reefs and sealevel change in Mangaia Island, Southern Cook Islands, Palaeogeogr. Palaeocl., 68, 171-188, 1988. 